\title{
Carbazole-based colorimetric anion sensors
}

\author{
Krystyna Maslowska-Jarzyna ${ }^{1}$, Maria L. Korczak ${ }^{1}$ Jakub A. Wagner ${ }^{1}$ and Michał J. Chmielewski 1,*
}

1 Faculty of Chemistry, Biological and Chemical Research Centre, University of Warsaw, Żwirki i Wigury 101, 02-089 Warsaw, Poland;

kmaslowska@chem.uw.edu.pl,ml.korczak@student.uw.edu.pl, ja.wagner@student.uw.edu.pl;

* Correspondence: mchmielewski@chem.uw.edu.pl

\begin{abstract}
Endowed with strong carbazole chromophore and fluorophore as well as with powerful and convergent hydrogen bond donors, 1,8-diaminocarbazoles are amongst the most attractive and synthetically versatile building blocks for the construction of anion receptors, sensors and transporters. Aiming at the development of carbazole-based colorimetric anion sensors, we describe here the synthesis of 1,8-diaminocarbazoles substituted with strongly electron-withdrawing substituents: 3,6-dicyano and 3,6-dinitro. Both of these precursors were subsequently converted into model diamide receptors. Anion binding studies revealed that the new receptors show greatly enhanced anion affinity, but also significantly increased acidity. We found also that rear substitution of $1,8-$ diamidocarbazole with two nitro groups shifts its absorption spectrum to the visible region and converts receptor into colorimetric anion sensor. The new sensor produces vivid changes in colour and fluorescence upon addition of basic anions in wet DMSO, but is poorly selective: due to its greatly enhanced acidity, for most anions the dominant receptor-anion interaction is proton transfer and, accordingly, similar changes in colour can be observed for every basic anion. The highly acidic and strongly binding receptors developed in this study may find applications in organocatalysis or in $\mathrm{pH}$-switchable anion transport through lipophilic membranes.
\end{abstract}

Keywords: supramolecular chemistry, anion recognition, anion receptors, anion sensors, colorimetric sensors

\section{Introduction}

Molecules that selectively change their colour or fluorescence in response to anionic species are highly appealing for applications in many branches of science, industry and medicine [1]. Such changes may be induced by hydrogen bonding interactions with anions, especially in cases where hydrogen bond donors are directly coupled with the receptor's chromophores or fluorophores [2-7]. If these changes are sufficiently strong and affect visible part of the spectra, they may even be detected by naked eye [2]. Significant research efforts have therefore been directed towards the development of colorimetric and fluorescent anion sensors based on hydrogen bond donating receptors [8-9].

One particularly appealing building block for the development of colorimetric and fluorescent anion sensors is $1,8-$ diaminocarbazole [10]. It combines several attractive features, such as the presence of a strong carbazole chromophore and fluorophore directly coupled with anion binding sites, strong hydrogen bond donor - carbazole NH, rigid skeleton that facilitates preorganization of auxiliary hydrogen bond donors and the ease of synthesis and derivatization. Diaminocarbazole-based receptors show particularly high affinity towards oxyanions (carboxylates, phosphates and sulphates) [3,11-24] and some of them are also very active anion transporters [22,25-26].

However, carbazole has negligible absorption in the visible part of the spectrum and accordingly, in the absence of other chromophores, diaminocarbazole-based receptors are colourless. It has been shown that substitution of positions 3 and 6 with mildly electron-withdrawing chlorine atoms shifts the UV spectrum of diamidocarbazoles almost to the verge of the visible region and, at the same time, increase their anion binding constants by up to an order of magnitude [22]. We hypothesized therefore, that more strongly electron-withdrawing substituents could turn such receptors into colorimetric anion sensors and, at the same time, enhance their binding constants even more significantly. In this paper we describe the synthesis and anion sensing properties of 3,6-dicyano- and 3,6-dinitro- substituted carbazole receptors 3 and 4 and compare them with the previously described [19,22] 3,6-unsubstituted and 3,6-dichlorosubstituted receptors 1 and 2 (Figure 1 ).
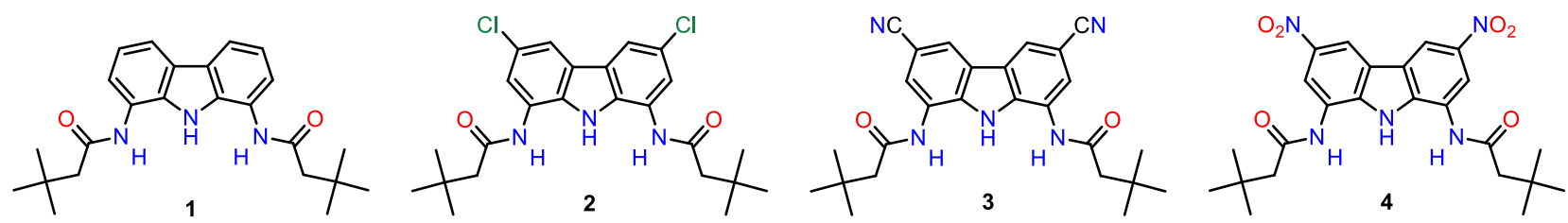

Figure 1. Model receptors used in this study. 


\section{Results and discussion}

\subsection{Synthesis}

Carbazole is electron rich and readily undergoes electrophilic aromatic substitution in positions 3 and 6. Only after these positions are blocked by, for example, chlorination, nitration smoothly goes into positions 1 and 8 giving the desired dinitro derivative: 3,6-dichloro-1,8-dinitrocarbazole 7 [27]. Subsequent reduction yields either 1,8-diamino-3,6dichlorocarbazole 8 [22] or 1,8-diaminocarbazole 9 [28], depending upon particular reagents and conditions. The two diamines have already been used for the synthesis of a variety of anion receptors, including amides, thioamides, sulfonamides and ureas [17-18,20,26]. Previously, we used them also for the synthesis of model receptors $\mathbf{1}$ and $\mathbf{2}$ (Scheme 1) $[19,22]$ :

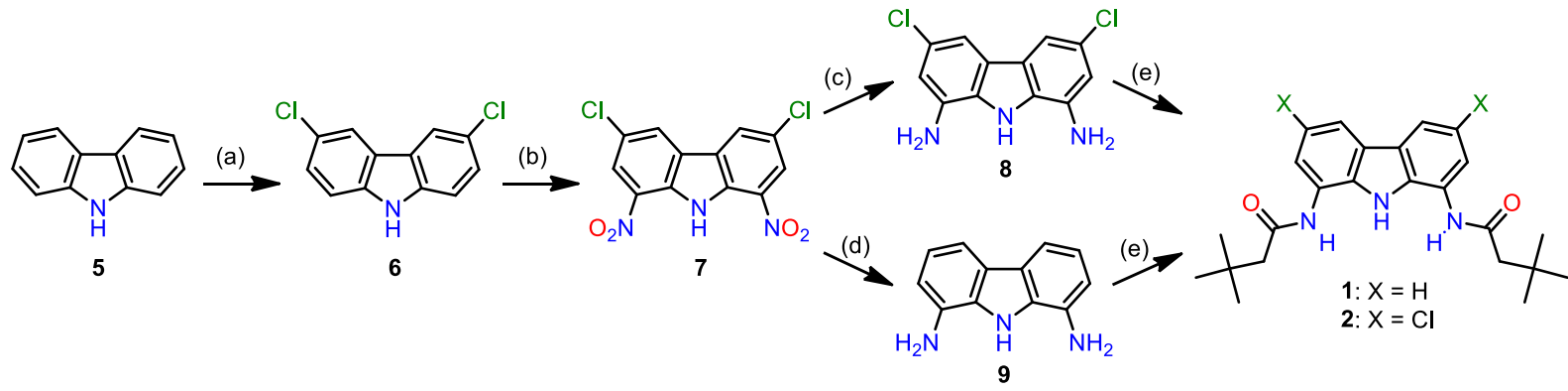

Scheme 1. The synthesis of receptors 1 and 2 [19,22]. (a) $\mathrm{SO}_{2} \mathrm{Cl}_{2}, \mathrm{CH}_{2} \mathrm{Cl}_{2}, \mathrm{RT}, 60 \%$. (b) $\mathrm{HNO}_{3}(100 \%), \mathrm{Ac} 2 \mathrm{O} / \mathrm{AcOH},{ }^{\circ} \mathrm{C}$ to $110{ }^{\circ} \mathrm{C}, 73 \%$. (c) $\mathrm{H}_{2}$ (balloon), $5 \% \mathrm{Pt}(\mathrm{S}) / \mathrm{C}$ (cat.), $\mathrm{CH}_{3} \mathrm{CN}, \mathrm{RT}, 90 \%$. (d) $\mathrm{NH}_{2} \mathrm{NH}_{2}, 10 \% \mathrm{Pd} / \mathrm{C}$ (cat.), EtOH, reflux, 6 h, $75 \%$. (e) $\left(\mathrm{CH}_{3}\right)_{3} \mathrm{CH}_{2} \mathrm{COCl}, \mathrm{Et} \mathrm{N}_{3}$, $\mathrm{CH}_{3} \mathrm{CN}, \mathrm{RT}, 40-88 \%$.

Similar strategy has been adopted in the present work for the synthesis of 3,6-dicyano substituted receptor 3 (Scheme 2).

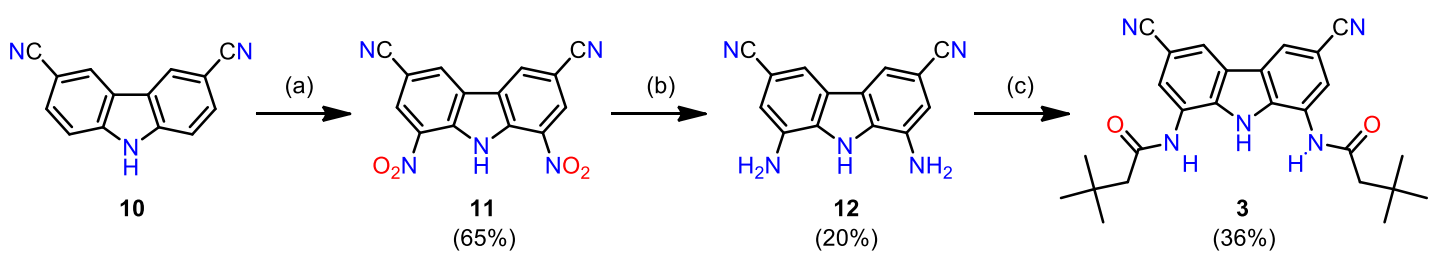

Scheme 2. The synthesis of receptor 3. (a) $\mathrm{HNO}_{3}(100 \%), \mathrm{Ac}_{2} \mathrm{O} / \mathrm{AcOH}, 1{ }^{\circ} \mathrm{C}$ to $110{ }^{\circ} \mathrm{C}, 12 \mathrm{~h}, 66 \%$; (b) $\mathrm{NH}_{2} \mathrm{NH}_{2} \cdot \mathrm{H}_{2} \mathrm{O}, \mathrm{FeSO}_{4} \cdot 7 \mathrm{H}_{2} \mathrm{O}, \mathrm{EtOH}_{\text {, }}$ reflux, 48 h, 20\%; (c) $\left(\mathrm{CH}_{3}\right)_{3} \mathrm{CH}_{2} \mathrm{COCl}$, DMA, RT, $24 \mathrm{~h}, 36 \%$.

The synthesis starts from 3,6-dicyanocarbazole 10, which is easily available in two steps from carbazole [29]. Nitration of $\mathbf{1 0}$ with acetyl nitrate (formed in situ from $100 \%$ nitric acid and acetic anhydride), under conditions optimized previously for the 3,6-dichlorocarbazole 6 [27], led to 2:1 mixture of mononitro- and dinitro- derivatives 14 and 11 (Scheme 3). This is apparently due to the stronger deactivation of the carbazole core by the -CN groups. On the other hand, much harsher conditions, such as boiling in the $\mathrm{HNO}_{3} / \mathrm{Ac} 2 \mathrm{O} / \mathrm{AcOH}$ mixture or using a mixture of concentrated sulfuric and nitric acids, lead to the extensive formation of degradation products or the formation of 1,3,6,8-tetranitrocarbazole 15, respectively. The reaction conditions were therefore carefully optimized, with particular emphasis on the reaction temperature and the substrate $/ \mathrm{HNO}_{3}$ and $\mathrm{HNO}_{3} / \mathrm{Ac}_{2} \mathrm{O}$ ratios.

Surprisingly, at $50{ }^{\circ} \mathrm{C}$ the main product turned out to be $N, N^{\prime}$-bis(3,6-dicyanocarbazole) 13 , with only traces of nitration products present in the reaction mixture after $40 \mathrm{~h}$ (Scheme 3). Heating at $70{ }^{\circ} \mathrm{C}$ for $40 \mathrm{~h} \mathrm{led} \mathrm{to} \mathrm{the} \mathrm{mixture} \mathrm{of}$ biscarbazole 13, 3,6-dicyano-1-nitrocarbazole 14 and small amounts of the desired 3,6-dicyano-1,8-dinitrocarbazole 11. Further increase of the reaction temperature to $90{ }^{\circ} \mathrm{C}$ resulted in the complete disappearance of $\mathbf{1 3}$ and preferential formation of the desired dinitrocarbazole 11. Unfortunately, however, significant amounts of the mononitro derivative 14 were still present in the reaction mixture under these conditions. The two nitro compounds are very difficult to separate and therefore the reaction conditions had to be optimized further to completely eliminate the formation of this by-product. To our delight, at $110^{\circ} \mathrm{C}$ very clean formation of the dinitro product was observed, somewhat surprisingly given that already at $118^{\circ} \mathrm{C}$ (the boiling point of the mixture) extensive decomposition takes place. Also, the nitrating 
reagent - acetyl nitrate - decomposes more and more rapidly at temperatures above $60^{\circ} \mathrm{C}$ [30]. As a consequence, the nitration at $110{ }^{\circ} \mathrm{C}$ requires large excess of $100 \% \mathrm{HNO}_{3}$ and is quite capricious.

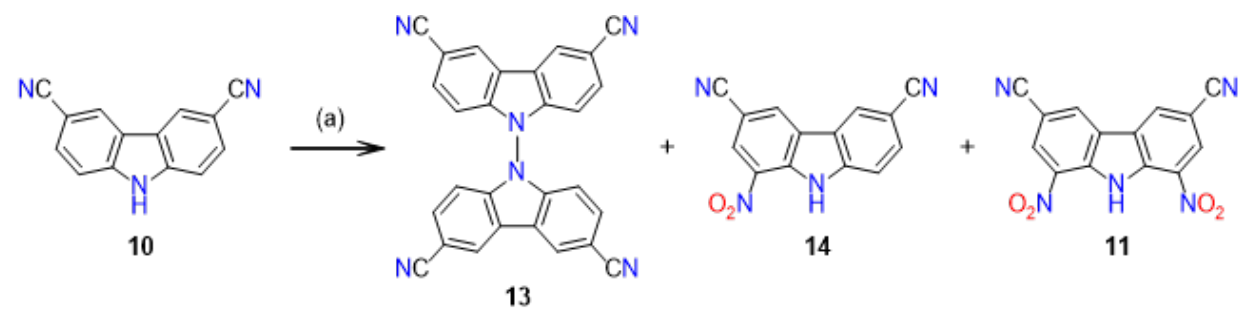

Scheme 3. Nitration of 3,6-dicyanocarbazole 10. (a) $\mathrm{HNO}_{3}(100 \%) / \mathrm{Ac}_{2} \mathrm{O} / \mathrm{AcOH}$, various temperatures.

To circumvent the extensive decomposition of acetyl nitrate, the nitric acid was added in small portions and the mixture was cooled down prior to each addition. Also, the reaction was monitored by ${ }^{1} \mathrm{H}$ NMR and continued until all the signals from $\mathbf{1 4}$ disappeared. Using these precautions, clean formation of $\mathbf{1 1}$ can be accomplished. The product precipitates from the reaction mixture in an almost pure form and can be obtained in $66 \%$ yield after simple filtration and washing with diethyl ether. It is worth noting that the 3,6-dicyano-1,8-dinitrocarbazole $\mathbf{1 1}$ might be a very useful synthon, because it bears as many as 5 amino group equivalents on a small, rigid core and is available in just three steps from the very cheap carbazole.

Selective reduction of the two nitro groups of $\mathbf{1 1}$ proved difficult, however, and gave the desired 1,8-diamino-3,6dicyanocarbazole $\mathbf{1 2}$ in just 20\% yield (not optimized). Also, the final acylation of $\mathbf{1 2}$ with $t$-butylacetyl chloride was more problematic then in the case of receptors 1 and 2, because the strongly electron withdrawing - $\mathrm{CN}$ groups make 3 prone to over-acylation, which leads to a very difficult to separate imide impurity. It was necessary therefore to develop a different protocol for this reaction. It turned out that in the absence of any base and in dimethylacetamide as a solvent the formation of the imide is suppressed, and the desired receptor 3 can be obtained in pure form, although in just $36 \%$ yield (Scheme 2).

Extension of the same synthetic strategy to the synthesis of receptor 4 seemed to be problematic because it requires selective reduction of only two of the four nitro groups of 1,3,6,8-tetranitrocarbazole 15 (Scheme 4). However, since the tetranitrocarbazole $\mathbf{1 5}$ is commercially available, we took up the challenge and, after some experimentation, found the appropriate reagent and conditions for this transformation. It turned out that 1,8-diamino-3,6-dinitrocarbazole $\mathbf{1 6}$ can be selectively obtained in $78 \%$ yield using hydrazine hydrate as reductor and iron(II) sulfate as catalyst [31]. This finding opens a very convenient access to another very attractive synthon, which also bears 5 amino group equivalents on a single carbazole core.

Acylation of $\mathbf{1 6}$ with $t$-butylacetyl chloride under standard conditions (AN, Et ${ }_{3} \mathrm{~N}$ ) also produces a difficult to separate imide impurity. As in the case of 3 described above, elimination of any base and application of dimethylacetamide as solvent suppressed the over-acylation and yielded pure receptor 4 in 58 \% yield (Scheme 4).

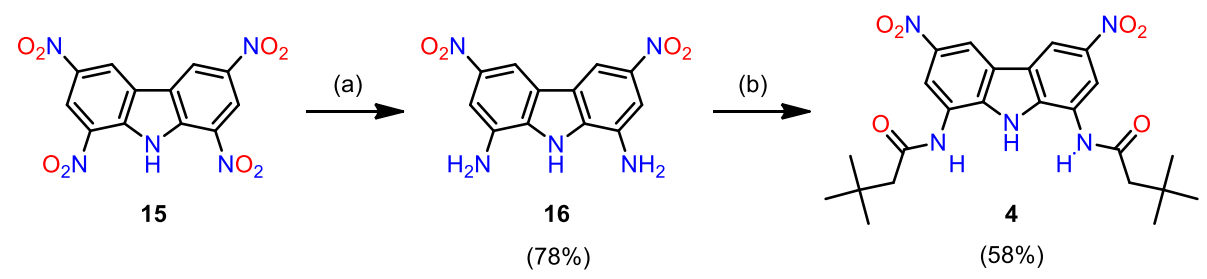

Scheme 4. Synthetic pathway leading to the receptor 4. Isolated yields are given in parentheses. (a) $\mathrm{NH}_{2} \mathrm{NH}_{2} \cdot \mathrm{H}_{2} \mathrm{O}, \mathrm{FeSO}_{4} \cdot 7 \mathrm{H}_{2} \mathrm{O}, \mathrm{EtOH}_{\text {, }}$ reflux, 20h; (b) 3,3-dimethylbutyryl chloride, DMA, RT, $20 \mathrm{~h}$.

\subsection{Anion recognition studies}

The anion binding studies with receptors 1 and 2 were described previously [19,22]. To aid comparison, the interaction of anions with receptors 3 and 4 were studied using the same methods and under identical conditions.

The results of ${ }^{1} \mathrm{H}$ NMR titrations of receptors 3 and 4 with tetrabutylammonium (TBA) chloride in DMSO-d $6+0.5 \%$ $\mathrm{H}_{2} \mathrm{O}$ are presented in Figure 2, together with the results for receptors $\mathbf{1}$ and $\mathbf{2}$. The comparison of chemical shifts of free 
receptors 1-4 revealed marked influence of the rear substituents $\mathrm{X}$ on the position of $\mathrm{NH}$ protons. The carbazole $\mathrm{NH}$ signal shifts from $9.99 \mathrm{ppm}$ for $\mathrm{X}=\mathrm{H}$, through $10.41 \mathrm{ppm}$ for $\mathrm{X}=\mathrm{Cl}$ and $11.22 \mathrm{ppm}$ for $\mathrm{X}=\mathrm{CN}$ to $11.49 \mathrm{ppm}$ for $\mathrm{X}=\mathrm{NO}_{2}$. Similar, but smaller downfield shifts (from 9.97 for 1 to 10.39 for $\mathbf{4}$ ) were observed for the amide NHs. It seems therefore, that as the electron withdrawing character of the 3,6-substituents increases, the two NH protons become more and more strongly engaged in hydrogen bonding interactions with the solvent molecules.

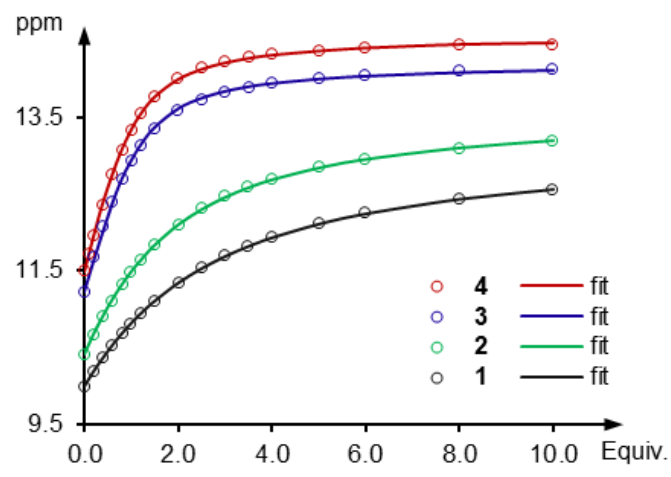

(a)

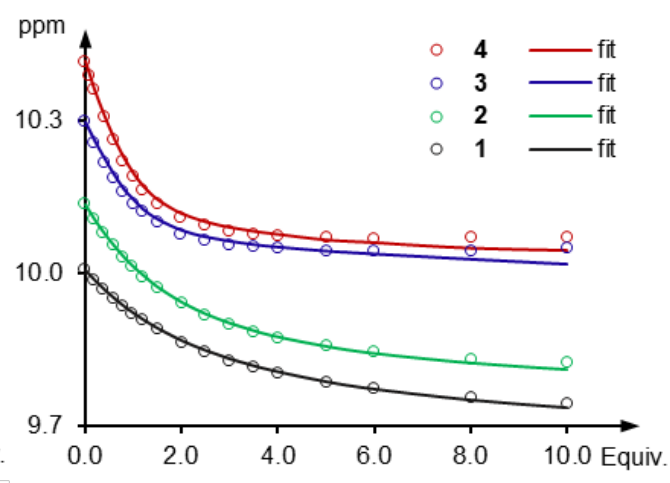

(b)

Figure 2. ${ }^{1} \mathrm{H}$ NMR titration curves of the (a) $\mathrm{NH}_{\text {carb. }}$ and (b) $\mathrm{NH}_{\text {amide }}$ signals of receptors 1-4 (10 mM) for TBACl in DMSO-d $6+0.5 \%$ $\mathrm{H}_{2} \mathrm{O}$ at $298 \mathrm{~K}$. 1:1 model fits are showed as the solid lines.

The addition of TBACl to the solution of each of the four receptors resulted in large downfield shifts of the carbazole $\mathrm{NH}$ protons $\left(\Delta \delta_{\max }=2.56,2.79,2.89\right.$ and $2.98 \mathrm{ppm}$, respectively) as well as in slight upfield shifts of the amide $\mathrm{NHs}$ $\left(\Delta \delta_{\max }=-0.27\right.$ for $1,-0.32$ for $2,-0.28$ for $3,-0.37$ for 4$)$. Apparently, the hydrogen bonds formed with the anion by the central carbazole NHs are much stronger than the bonds formed with the two amide side arms. The rather uncommon upfield shifts of the amide protons upon chloride binding by this family of receptors suggest that strong hydrogen bonding interactions with solvent molecules deshields these protons more than the hydrogen bonding with chloride.

These suppositions are supported by the X-ray crystal structures of the chloride complexes of diamides $\mathbf{3}$ and $\mathbf{4}$, in which the carbazole $\mathrm{NH}-\mathrm{Cl}$ distances are much shorter (2.198 and $2.170 \AA$, respectively) than the amide $\mathrm{NH}-\mathrm{Cl}$ distances (2.533 - $2.595 \AA$ ), see Figure 3 and Table 1. The asymmetric position of chloride in the cavity of 4 suggests also that while the anion is able to form shorter bonds with amide $(2.533 \AA)$, the cavity of the receptor is too wide to allow for the simultaneous formation of two short bonds with this relatively small guest. Very likely therefore, in solution the anion rapidly jumps between two equivalent positions, in which it is closer to either one or another amide arm. Since the observed chemical shifts of the amide protons are averaged over all conformations (fast exchange regime), this hypothesis explains the rather weak effect of chloride binding on the chemical shift of amide protons.

a)

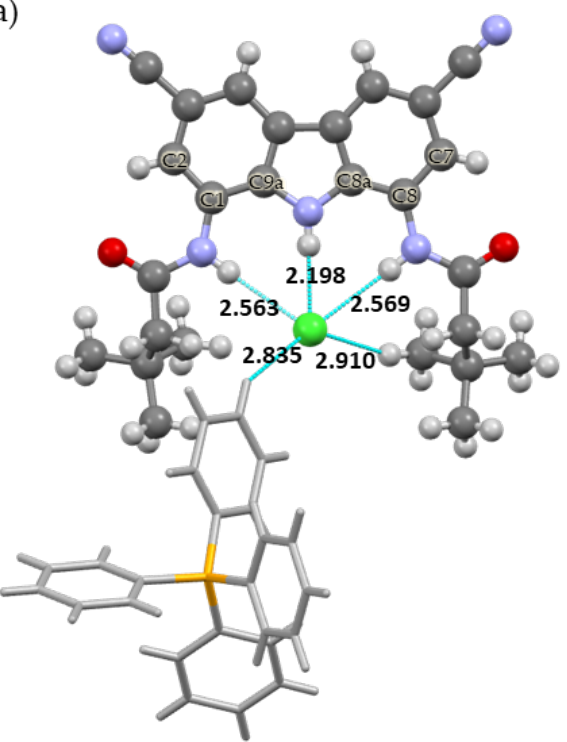

b)

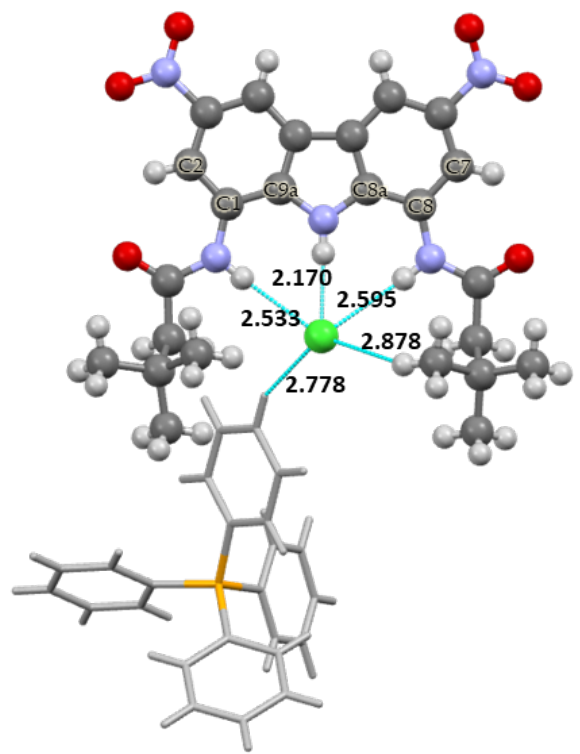

Figure 3. Crystals structures of a) $3 \times \mathrm{Cl}^{-}$and b) $4 \times \mathrm{Cl}^{-}$. 
Table 1. Hydrogen bonding distances and selected torsion angles in the X-ray crystal structures of chloride complexes of 3 and 4.

\begin{tabular}{|c|c|c|c|}
\hline Parameter & Atom & $3 \times \mathrm{Cl}$ & $4 \times \mathrm{Cl}$ \\
\hline \multirow{5}{*}{ Bond length, $\AA$} & $\mathrm{Cl} \cdots \mathrm{NH}_{\text {carb. }}$ & 2.198 & 2.170 \\
\hline & $\mathrm{Cl} \cdots \mathrm{NH}_{\text {amide } 1}$ & 2.563 & 2.533 \\
\hline & $\mathrm{Cl}^{-\cdots} \cdot \mathrm{NH}_{\text {amide2 }}$ & 2.569 & 2.595 \\
\hline & $\mathrm{Cl}^{-\cdots} \mathrm{CH}_{\mathrm{t}-\mathrm{Bu}}$ & 2.910 & 2.878 \\
\hline & 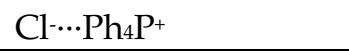 & 2.835 & 2.778 \\
\hline \multirow{2}{*}{ Torsion angle $\varphi,^{\circ}$} & C2-C1-Namide1-Camide1 & 3.80 & 5.00 \\
\hline & C7-C8-Namide2-Camide2 & -5.22 & 0.38 \\
\hline \multirow{2}{*}{ Torsion angle $\varphi,^{\circ}$} & C9a-C1-Namide1-Camide1 & -178.32 & -176.94 \\
\hline & C9a-C8-Namide2-Camide2 & 177.43 & 174.60 \\
\hline
\end{tabular}

Quantitative analysis of the titration curves was performed using web applet BindFit [32]. Excellent fits were obtained using simple 1:1 binding model and the association constants thus obtained are presented in Table 2. As expected, substitution of positions 3 and 6 with strongly electron-withdrawing cyano groups enhances chloride affinity more than 6-fold with respect to the unsubstituted $\mathbf{1}$ and ca. 2-fold with respect to chlorine substituted 2 . The introduction of even more strongly electron withdrawing nitro groups resulted in further increase in the $\mathrm{Cl}^{-}$affinity, with binding constant reaching value 7 times higher than for the unsubstituted receptor $\mathbf{1}$.

Table 2. Binding constants of receptors 1-4 with various anions in DMSO- $\mathrm{d}_{6}+0.5 \% \mathrm{H}_{2} \mathrm{O}$ at $298 \mathrm{~K}$.

\begin{tabular}{ccccc}
\hline Receptor & $\boldsymbol{K}_{a} \mathbf{C l} \mathbf{l}^{- \text {aa }}$ & $\boldsymbol{K}_{a} \mathbf{P h C O O}^{-}$ & $\boldsymbol{K}_{a} \mathbf{H}_{2} \mathrm{PO}_{4}^{-}$ & $\boldsymbol{K}_{a} \mathrm{CH}_{3} \mathrm{COO}^{-}$ \\
\hline $\mathbf{1}$ & 48 & $10^{3.67}$ & $10^{4.01}$ & $10^{4.07}$ \\
$\mathbf{2}$ & 159 & $10^{4.47}$ & $10^{4.91}$ & $10^{4.95}$ \\
$\mathbf{3}$ & 309 & deprotonation & $10^{5.4}$ & n.d. \\
$\mathbf{4}$ & 347 & deprotonation & deprotonation & n.d. \\
\hline
\end{tabular}

[a] $\mathrm{DMSO}-\mathrm{d}_{6}+0.5 \% \overline{\mathrm{H}_{2} \mathrm{O}}$

* - estimated complexation constant, disregarding partial deprotonation.

The binding constants of 1,8-diamidocarbazoles with benzoate and dihydrogen phosphate typically exceed the range which could be reliably determined by NMR titrations. Fortunately, owing to the carbazole chromophore, this class of receptors is perfectly suited for studying anion binding processes using UV-Vis spectroscopy. The addition of oxyanions (as TBA salts) to the solutions of receptors 3 and 4 in DMSO $+0.5 \% \mathrm{H}_{2} \mathrm{O}$ led to vivid changes in absorbance between 300 and $600 \mathrm{~nm}$ (Figure 4).

However, the absence of well-defined isosbestic points and the formation of characteristic peaks at $372 \mathrm{~nm}$ (for 3 ) and at $515 \mathrm{~nm}$ (for 4), suggest that the observed changes are not only due to anion binding, but also due to proton transfer from the receptors to the basic anions. In case of 3 and $\mathrm{H}_{2} \mathrm{PO}_{4}^{-}$, the proton transfer becomes significant only after most of the receptor molecules are bound with the anion, which allowed us to estimate anion binding constant from truncated titration curve. The value thus obtained, $\log \mathrm{K}=\mathrm{ca} .5 .4$, is well in line with the values obtained earlier for 1 and 2 (Table 2) and is also consistent with the expected increase in anion affinity with increasing electron-withdrawing character of the 3,6 substituents. It agrees also with the observed rapid saturation of the complexation-induced changes in the UV-Vis spectra, which occurs after the addition of just 1.6 equivalents of $\mathrm{H}_{2} \mathrm{PO}_{4}^{-}$(at $10^{-4} \mathrm{M}$ concentration of 3 ). In case of 4, however, the proton transfer dominates over anion binding, and all attempts to separate the two processes were unsuccessful. 

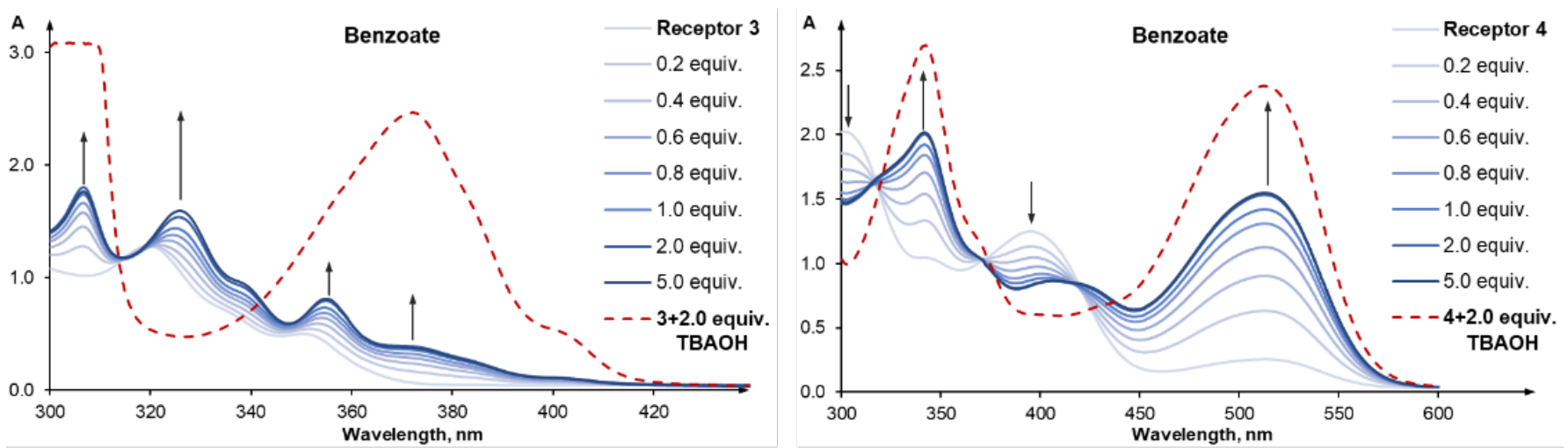

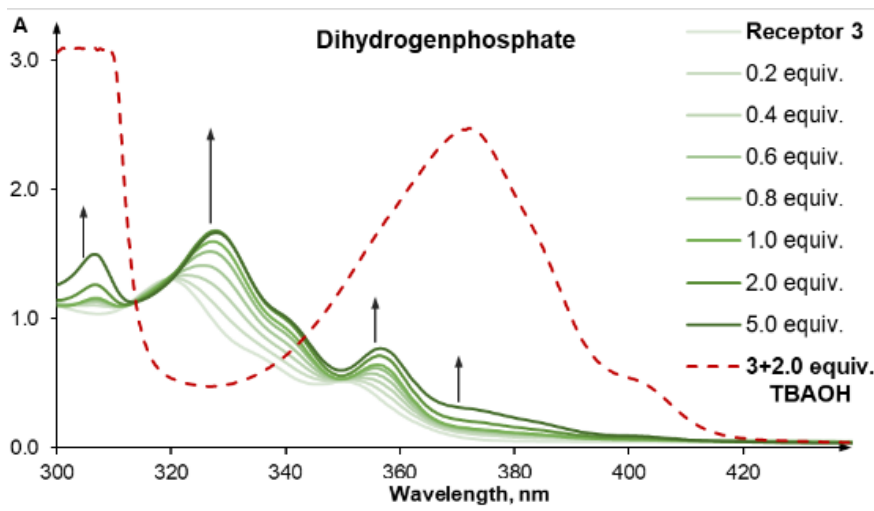

(a)

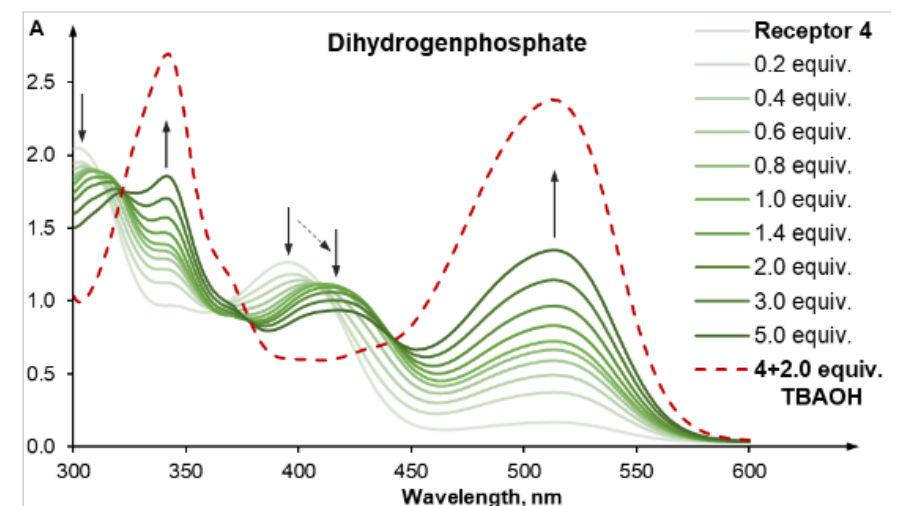

(b)

Figure 4. UV-Vis titration of: (a) $3\left(10^{-4} \mathrm{M}\right)$ with TBAPhCOO (up) and $\mathrm{TBAH}_{2} \mathrm{PO}_{4}$ (down); (b) 4 (10-4 M) with $\mathrm{TBAPhCOO}$ (up) and $\mathrm{TBAH}_{2} \mathrm{PO}_{4}$ (down) in DMSO $+0.5 \% \mathrm{H}_{2} \mathrm{O}$ at $298 \mathrm{~K}$.

\subsection{Self-dissociation studies}

Careful analysis of the UV-vis titration data presented above revealed that receptors 3 and 4 are slightly deprotonated even before the addition of any anion (Figure 5). Indeed, further dilution of the receptors beyond the $10^{-4} \mathrm{M}$ concentration used in the titration experiments led to marked increase of the extent of self-ionization, in accord with the Ostwald's dilution law. At $5 \times 10^{-6} \mathrm{M}$, even the less acidic 3 seems to be completely ionised (Figure 5a). Titration with trifluoromethanesulfonic acid (TfOH) reverses the self-ionization of both receptors (see ESI for 3 and Figure $5 b$ for 4 ). It is worth to note that even very small degree of spontaneous dissociation may lead to erroneous conclusions about, inter alia, colour, fluorescence, and anion sensing properties of receptors (see, for example, Figure 6). Therefore, we report UV-Vis spectra and photographs of solutions of $\mathbf{3}$ and $\mathbf{4}$ in the presence of two equivalents of TfOH (Figure 7).

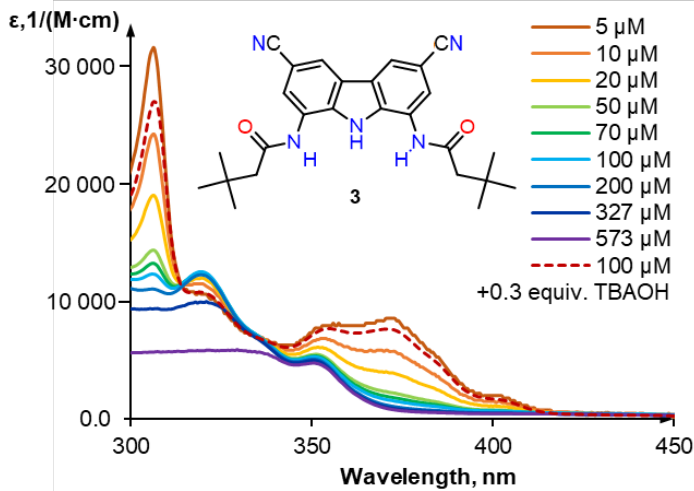

(a)

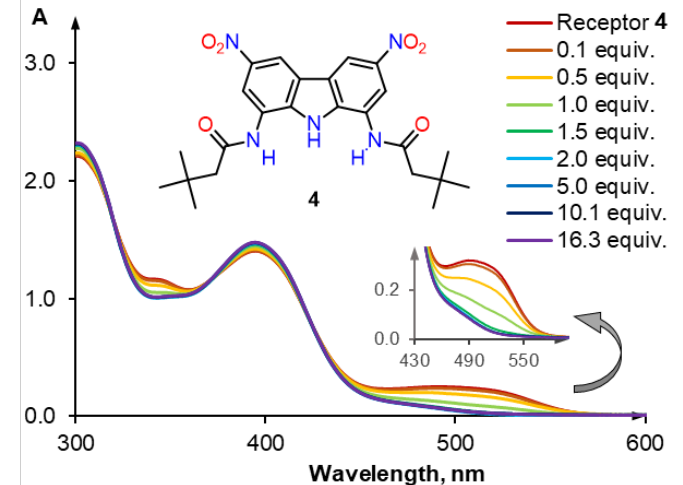

(b)

Figure 5. Self-ionization studies. (a) Self-ionization of diluted solutions of 3 in DMSO $+0.5 \% \mathrm{H}_{2} \mathrm{O}$ at $298 \mathrm{~K}\left(A_{\text {norm. }}=573 \mu M^{*} A / C\right)$; (b) Reversal of self-ionization of $4\left(10^{-4} \mathrm{M}\right)$ upon titration with $\mathrm{TfOH}$ in $\mathrm{DMSO}+0.5 \% \mathrm{H}_{2} \mathrm{O}$ at $298 \mathrm{~K}$. 

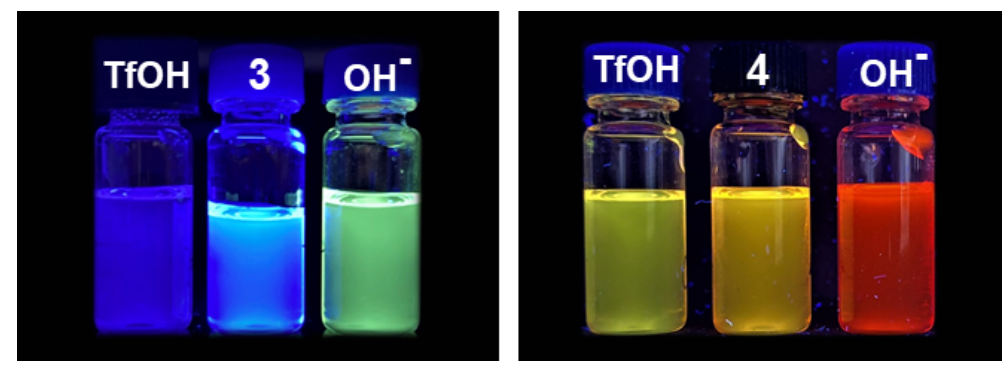

Figure 6. Fluorescence colour change of 3 (left) and 4 (right) at $10^{-4} \mathrm{M}$ in the presence of 2 equivalents of TfOH or 2 equivalents of $\mathrm{TBAOH}$ in $\mathrm{DMSO}+0.5 \% \mathrm{H}_{2} \mathrm{O}$ observed under UV lamp $(365 \mathrm{~nm})$.

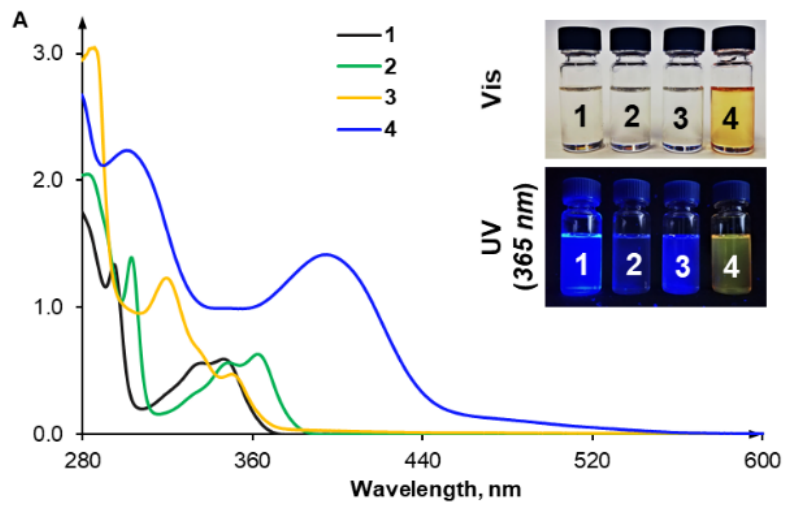

Figure 7. UV-Vis spectra of receptors $1-4\left(10^{-4} \mathrm{M}\right)$ in the presence of 2 equiv. of $\mathrm{TfOH}$ in DMSO $+0.5 \% \mathrm{H}_{2} \mathrm{O}$ at $298 \mathrm{~K}$. Inset: the same solutions under visible light and under UV irradiation $(365 \mathrm{~nm})$.

\subsection{Anion sensing properties of $\mathbf{3}$ and $\mathbf{4}$}

As shown in Figure 7, the introduction of nitro groups successfully shifted the absorbance spectrum of 4 to the visible region (> $400 \mathrm{~nm}$ ). Accordingly, both 4 and its solutions are intensely yellow. Similar effect, however, was not observed for cyano groups, and the long wavelength part of the spectrum vanishes even faster for $\mathbf{3}$ than for 2.

To investigate the sensory properties of $\mathbf{3}$ and $\mathbf{4}$ we added various anions (as their TBA salts) to the solutions of the two receptors in DMSO $+0.5 \% \mathrm{H}_{2} \mathrm{O}$ (Figure 8). Anions having different shapes, solvation energies and basicity were selected: $\mathrm{F}^{-}, \mathrm{Cl}^{-}, \mathrm{Br}^{-}, \mathrm{I}^{-}, \mathrm{NO}_{3}^{-}, \mathrm{AcO}^{-}, \mathrm{PhCOO}^{-}, \mathrm{H}_{2} \mathrm{PO}_{4}{ }^{-}, \mathrm{CN}^{-}, \mathrm{HSO}_{4}^{-}$and $\mathrm{SO}_{4}{ }^{2-}$.

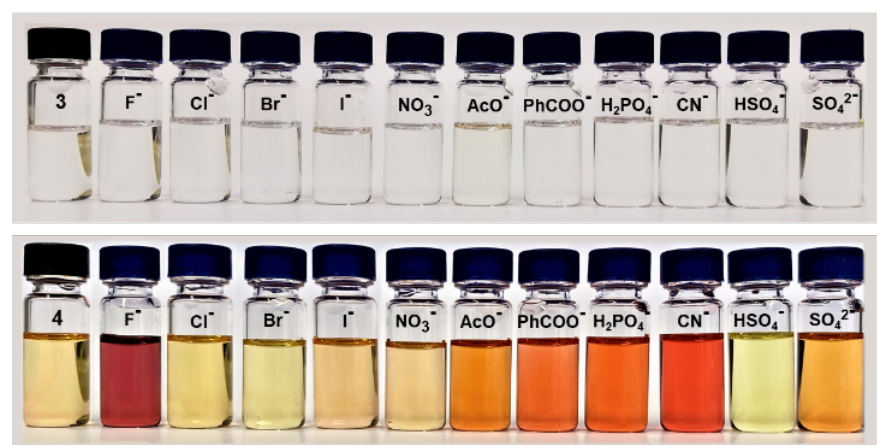

(a)
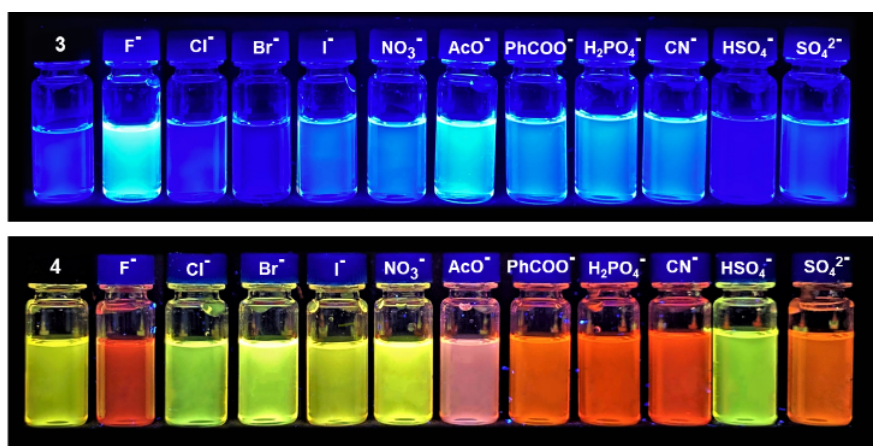

(b)

Figure 8. Colour change of $10^{-4} \mathrm{M}$ solutions of 3 and 4 in the presence of 10 equiv. of various anions (added as their tetrabutylammonium salts) in DMSO $+0.5 \% \mathrm{H}_{2} \mathrm{O}$ : (a) under ambient light and (b) under UV lamp (365 nm).

No colour change was observed for $\mathbf{3}$, in accord with the very weak absorption of 3 and its complexes in the visible region (Figure 4a). Much more significant changes, however, were observed under UV irradiation $\left(\lambda_{\mathrm{ex}}=365 \mathrm{~nm}\right)$. Significant enhancement in fluorescent emission is clearly visible in all the samples containing the most basic anions: $\mathrm{F}^{-}$, $\mathrm{AcO}^{-}, \mathrm{PhCOO}-\mathrm{H}_{2} \mathrm{PO}_{4}^{-}$and $\mathrm{CN}^{-}$. This is because the deprotonated 3 is strongly emissive in the visible region. Quenching of fluorescence was observed for $\mathrm{HSO}_{4}^{-}$, most likely because this anion acts like Brønsted acid and reverses the spontaneous dissociation of 3 , diminishing the concentration of the highly emissive $\left[3-\mathrm{H}^{+}\right]^{-}$. 
In contrast, receptor 4 displays a very nice colorimetric response towards $\mathrm{F}^{-}, \mathrm{AcO}^{-}, \mathrm{PhCOO}^{-}, \mathrm{H}_{2} \mathrm{PO}_{4}^{-}, \mathrm{CN}^{-}$and $\mathrm{SO}_{4}{ }^{2-}$ , changing colour from yellow to orange or burgundy (Figure 8a). Almost no change was observed upon addition of $\mathrm{Cl}^{-}, \mathrm{Br}^{-}, \mathrm{I}^{-}, \mathrm{NO}_{3}^{-}$and $\mathrm{HSO}_{4}^{-}$. Since the colorimetric response is observed only for basic anions and is similar for all of them, it is most likely dominated by the deprotonation of the receptor. As discussed above, both anion binding and receptor deprotonation shift the absorption spectra of $\mathbf{3}$ and $\mathbf{4}$ to the right and both processes coexist for $\mathrm{PhCOO}^{-}$and $\mathrm{H}_{2} \mathrm{PO}_{4}^{-}$in wet DMSO. However, in case of the more acidic 4, proton transfer dominates, and this is further amplified by the fact that the extinction coefficients of $\left[4-\mathrm{H}^{+}\right]^{-}$are much higher than of $\left[4 \times \mathrm{A}^{-}\right]^{-}$. As a result, the colorimetric response of $\mathbf{4}$ is poorly specific, i.e. very similar for all basic anions. Similar behaviour is commonly observed in many hydrogen bonding anion sensors [9].

The above conclusions gain additional support from anion-induced changes in the fluorescence of 4 . Under UV irradiation $(365 \mathrm{~nm})$ dramatic changes in emission from yellow-green to orange-red can be seen upon addition of basic anions: $\mathrm{F}^{-}, \mathrm{NO}_{3}{ }^{-}, \mathrm{AcO}^{-}, \mathrm{PhCOO}, \mathrm{H}_{2} \mathrm{PO}_{4}^{-}, \mathrm{CN}^{-}$and $\mathrm{SO}_{4}{ }^{2-}$, whereas little or no change is induced by $\mathrm{Cl}^{-}, \mathrm{Br}^{-}, \mathrm{I}^{-}, \mathrm{NO}_{3}^{-}$and $\mathrm{HSO}_{4}{ }^{-}$. Again, the weakly basic and weakly binding anions from the latter group cause negligible changes, whereas all the anions from the former group deprotonate 4 to a greater or lesser extent, switching the greenish-yellow fluorescence of the receptor into the orange-red fluorescence of deprotonated receptor. Unlike for 3 , the doubly charged sulfate also deprotonates 4 , in accord with the increased acidity of this receptor.

Unfortunately, more detailed spectrofluorimetric investigations of 3, 4 and their interaction with anions were hampered by the spontaneous dissociation of the receptors in highly diluted solutions, typically used in fluorescence measurements.

\section{Conclusions}

In this contribution we describe the synthesis of two novel building blocks for the construction of anion receptors: 1,8-diamino-3,6-dicyanocarbazole 12 and 1,8-diamino-3,6-dinitrocarbazole 16. Both are interesting not only in the context of anion recognition, but also as high-potential synthons for organic synthesis in general, because they present as many as 5 amino group equivalents on a single carbazole core.

We synthesised also two new 1,8-diamidocarbazole receptors with strongly electron withdrawing 3,6-dicyano and 3,6-dinitro substituents. Both of them display significantly improved anion affinity as compared to the unsubstituted and 3,6-dichloro substituted receptors, but are also much more prone to proton abstraction. Carboxylates, phosphates and sulfate significantly deprotonate these receptors in wet DMSO, what limits their utility in anion recognition. In this way, we have experimentally established the limits of anion affinity enhancement that can be achieved by the substitution of the carbazole platform.

The new 3,6-dinitro substituted receptor 4 acts as colorimetric anion sensor in wet DMSO, producing distinct colour changes upon interaction with basic anions. Unfortunately, however, these changes are mostly due to receptor deprotonation, and therefore lack specificity. In contrast to 4, the 3,6-dicyano substituted receptor 3 is colourless and produces no significant colour changes upon addition of anions. However, it also undergoes deprotonation by many basic anions, what manifests under UV irradiation as marked enhancement in fluorescence intensity.

Owing to their very high hydrogen bond donating ability combined with relatively high Bronsted acidity, diamidocarbazoles similar to 3 and 4 may find applications in, for example, organocatalysis [33] or in pH-switchable anion transport through lipophilic membranes [34-37]. Research in these directions is ongoing in our laboratories and will be published in due course.

\section{Materials and Methods}

\subsection{General Experimental}

\subsubsection{Chemicals and Consumables}

All solvents and reagents were commercially available and used as received unless otherwise stated. Reagents for this study were purchased from the following vendors:

- Merck-Sigma: N,N-dimethylacetamide anhydrous (DMA, 99.8\%, 271012), 3,3-dimethylbutyryl chloride (tert-butylacetyl chloride, 99\%, B88802), N,N-dimethylformamide (DMF, puriss. p.a., ACS reagent, reag. Ph. Eur., $\geq 99.8 \%$ (GC), 33120), dimethyl sulfoxide (DMSO, anhydrous, $\geq 99.9 \%, 276855)$, hydrazine monohydrate $\left(\mathrm{N}_{2} \mathrm{H}_{4} \cdot \mathrm{H}_{2} \mathrm{O}, 64-65 \%\right.$, reagent grade, $98 \%, 207942$ ), iron(II) sulfate heptahydrate ( $\left.\mathrm{FeSO}_{4} \cdot 7 \mathrm{H}_{2} \mathrm{O}, \geq 99.0 \%, 215422\right)$, methanol (MeOH for HPLC, $\geq 99.9 \%, 34860$ ), nitric acid fuming $\left(\mathrm{HNO}_{3}\right.$, extra pure, $\left.100 \%, 1004551000\right)$, sodium hydroxide solution (2N NaOH, Titripur, 1091361000), tetrabutylammonium chloride (TBACl, $\geq 99.0 \%, 86852)$, tetrabutylammonium benzoate (TBAPhCOO, $299.0 \%, 86837$ ), tetrabutylammonium phosphate monobasic $\left(\mathrm{TBAH}_{2} \mathrm{PO} 4, \geq 99.0 \%(\mathrm{~T}), 86833\right)$. 
- POCH: acetic acid (AcOH, 99.5-99.9\%, pure p.a.-basic, BA8760114), acetic anhydride ( $\mathrm{Ac}_{2} \mathrm{O}, \mathrm{ACS}$ reagent, pure p.a., 693870115), ethyl alcohol anhydrous ( $\mathrm{EtOH}, 99.8 \%$ pure p.a., 396480111), nitric acid $\left(\mathrm{HNO}_{3}, 65 \%\right.$, pure p.a., BA9603115), hydrochloric acid ( $\mathrm{HCl}, 35-38 \%$, pure p.a., BA5283115).

- TCI: 1,3,6,8-tetranitrocarbazole (wetted with ca. $40 \%$ water, $>70.0 \%$, T0159).

- Alfa Aesar: trifluoromethanesulfonic acid (TfOH, anhydrous, $98 \%$ ).

- Euriso-top: DMSO-d $6+0.03 \% \mathrm{TMS} \mathrm{v} / \mathrm{v}(>99.8 \% \mathrm{D})$.

Water was taken from Milli-Q purification system. DMSO/ $\mathrm{H}_{2} \mathrm{O}$ mixtures were obtained using Milli-Q $\mathrm{H}_{2} \mathrm{O}$ and its concentration is expressed as weight-weight percentage.

\subsubsection{Instruments and methods}

Samples were weighed on Mettler Toledo Excellence XA105DU analytical balance. High-resolution ESI-MS spectra were obtained using a Maldi SYNAPT G2-S HDMS mass spectrometer with direct fusion. Elemental analysis was performed using an automatic UNIcube elemental analyzer. UV-Vis spectra were obtained on Thermo Scientific Evolution $300 \mathrm{UV}$-Vis spectrophotometer. NMR spectra were recorded using Agilent NMR $\left({ }^{1} \mathrm{H}: 400 \mathrm{MHz},{ }^{13} \mathrm{C}: 100 \mathrm{MHz}\right)$ spectrometer at ambient temperature in DMSO- $\mathrm{d} 6$. The chemical shifts, $\delta$, are reported in parts per million (ppm) and coupling constants, J, are given in hertz $(\mathrm{Hz})$. The NMR spectra were referenced to the solvent residual signal $\left({ }^{1} \mathrm{H}\right.$ : $\delta$ Dmso $\left.=2.50 \mathrm{ppm},{ }^{13} \mathrm{C}: \delta_{\mathrm{DMsO}}=39.50 \mathrm{ppm}\right)$. Data are reported as follows: chemical shift, multiplicity (s - singlet, bs - broad singlet, $\mathrm{d}$ - doublet, $\mathrm{t}$ - triplet, $\mathrm{dd}$ - doublet of doublets, $\mathrm{dt}$ - doublet of triplets, etc.), coupling constant and integration.

\subsection{Synthesis}

\subsubsection{General methods}

TLC was carried out on Merck silica gel 60 F 254 plates. Preparative chromatography was done using a Teledyne Isco CombiFlash system with RediSep Normal-phase Silica Flash Columns. The compositions of eluent mixtures used in chromatographic separations are reported as (v/v) ratios.

\subsubsection{Synthesis of the previously reported receptors 1 and $\mathbf{2}$}

Receptor 1 was obtained in one-step from 1,8-diaminocarbazole [28], as described previously [22]. Receptor 2 was obtained in one-step from 1,8-diamino-3,6-dichlorocarbazole [22], as described previously [19].

\subsubsection{Synthesis of receptor 3}

Receptor 3 was obtained in a three-steps synthesis from the previously described 3,6-dicyjanocarbazole 10 [29].

\section{Synthesis of 3,6-dicyano-1,8-dinitrocarbazole 11}

To a $50 \mathrm{ml}$ round-bottom two-neck flask equipped with a magnetic stirrer 3,6-dicyanocarbazole $(0.652 \mathrm{~g}, 3.00$ $\mathrm{mmol})$, acetic anhydride $(10 \mathrm{ml}, 0.11 \mathrm{~mol})$ and acetic acid $(13 \mathrm{ml}, 0.23 \mathrm{~mol})$ were added. The flask was equipped with a reflux condenser connected to a check-valve bubbler and through the side neck of the flask $100 \%$ nitric acid $(0.79 \mathrm{ml}$, $19 \mathrm{mmol}$ ) was added drop-by-drop using Pasteur pipette. The neck was tightly closed with a glass stopper and the mixture was heated with stirring to $110^{\circ} \mathrm{C}$ (measured in oil bath). After 50 minutes (from the beginning of the heating), the reaction mixture was cooled down for 10 minutes at room temperature and another portion of $100 \%$ nitric acid ( 0.79 $\mathrm{ml}, 19 \mathrm{mmol}$ ) was added. The mixture was heated to $110^{\circ} \mathrm{C}$ again and this procedure was repeated four times: $3.16 \mathrm{ml}$ $(76 \mathrm{mmol})$ of nitric acid were added in total. The addition of the fifth portion of $100 \%$ nitric acid $(0.79 \mathrm{ml}, 19 \mathrm{mmol})$ was preceded by the addition of acetic anhydride $(2 \mathrm{ml}, 21 \mathrm{mmol})$. This procedure was repeated five times: $10 \mathrm{ml}(105 \mathrm{mmol})$ of acetic anhydride and $3.95 \mathrm{ml}(95 \mathrm{mmol})$ of nitric acid were added in total. After the eighth addition of $\mathrm{HNO}_{3} / \mathrm{HNO}_{3}+\mathrm{Ac}_{2} \mathrm{O}$ the progress of the reaction was checked by ${ }^{1} \mathrm{H}$ NMR and additional portions of $\mathrm{HNO}_{3}+\mathrm{Ac}_{2} \mathrm{O}$ were added until the signal from 3,6-dicyano-1-mononitrocarbazole disappeared. After cooling the reaction mixture to RT, $50 \mathrm{ml}$ of deionized water were added. The precipitate was filtered off and washed with water $(2 \times 15 \mathrm{ml}), \mathrm{MeOH}(2 \times 5$ $\mathrm{ml})$ and diethyl ether $(2 \times 5 \mathrm{ml})$. Vacuum drying yielded pure product as a yellow powder $(0.609 \mathrm{~g}, 66 \%)$.

${ }_{1} \mathrm{H}$ NMR (400 MHz, DMSO-d6) סDmso: 11.79 (s, 1H, NHcarb.), 9.30 (d, J 1.43, 2H, CH4/5 or CH2/7), 8.98 (d, J 1.41, 2H, CH4/5

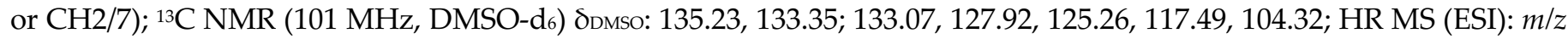
calcd. for $\mathrm{C}_{14} \mathrm{H}_{4} \mathrm{~N}_{5} \mathrm{O}_{4}[\mathrm{M}-\mathrm{H}]^{-}: 306.0269$ found: 306.0263 . 
Synthesis of 1,8-diamino-3,6-dicyanocarbazole

To a $50 \mathrm{ml}$ round-bottom two-neck flask equipped with a magnetic stirrer, 3,6-dicyano-1,8-dinitrocarbazole (0.614 $\mathrm{g}, 2.00 \mathrm{mmol})$ and anhydrous $\mathrm{EtOH}(30 \mathrm{ml})$ were added. The flask was equipped with a reflux condenser connected to a check-valve bubbler, the side neck was sealed with a septum and argon was bubbled through the mixture for 10 minutes with slow stirring. After this time, $\mathrm{FeSO}_{4} \cdot 7 \mathrm{H}_{2} \mathrm{O}(37 \mathrm{mg}, 0.13 \mathrm{mmol})$ was added and argon was bubbled through the mixture for additional $15 \mathrm{~min}$. Then, in the flow of argon, $98 \%$ hydrazine monohydrate $\mathrm{NH}_{2} \mathrm{NH}_{2} \cdot \mathrm{H}_{2} \mathrm{O}(3.90 \mathrm{ml}, 80$ $\mathrm{mmol}$ ) was added dropwise. The mixture was heated to reflux and stirred for $48 \mathrm{~h}$. After cooling to RT, the precipitate was filtered off and suspended in dimethylformamide (ca. $7 \mathrm{ml})$. The product dissolved in DMF and was separated from insoluble impurities by filtration. Next, methanol $(60 \mathrm{ml})$ was added to the filtrate and precipitated impurities were filtered off again using G4 sintered glass filter. Finally, deionized water (40 ml) with a few droplets of hydrazine monohydrate (to protect the product from air oxidation) was added to the filtrate in order to precipitate the desired product. The suspension was boiled for 10 minutes, cooled down to RT and put into a refrigerator for $24 \mathrm{~h}$. The product was filtered off and washed with water $(3 \times 3 \mathrm{ml})$. Vacuum drying yielded product which was sufficiently pure for subsequent reaction (brown powder, $0.096 \mathrm{~g}, 20 \%$ ).

${ }^{1} \mathrm{H}$ NMR (400 MHz, DMSO-d6) రDMso: 11.46 (s, 1H, NHcarb), 7.94 (d, J 1.36, 2H, CH4/5 or CH2/7), 6.95 (d, J 1.47, 2H, CH4/5 or CH2/7), 5.58 (s, 4H, NH2); ${ }^{13} \mathrm{C}$ NMR (101 MHz, DMSO-d6) ठрмso: 135.23, 133.35, 133.07, 127.92, 125.26, 117.49, 104.32; HR MS (ESI): $m / z$ calcd. for $\mathrm{C}_{14} \mathrm{H}_{8} \mathrm{~N}_{5}$ [M-H]-: 246.0785 found: 246.0780.

\section{Synthesis of receptor 3}

A $5 \mathrm{ml}$ round-bottom flask was dried with a heat gun (set to ca. $500^{\circ} \mathrm{C}$ ) for 10 minutes, and then cooled down to RT in a desiccator. To the flask, 1,8-diamino-3,6-dicyanocarbazole $(0.050 \mathrm{~g}, 0.20 \mathrm{mmol})$ and a magnetic stirrer were added. The neck of the flask was sealed with a septum and the flask was filled with argon by three pump-thaw cycles. Anhydrous dimethylacetamide $(3 \mathrm{ml})$ was added via a syringe, followed by the addition of 3,3-dimethylbutyryl chloride $(0.090 \mathrm{ml}, 0.64 \mathrm{mmol})$. The reaction mixture was stirred at RT for $20 \mathrm{~h}$. After this time, the reaction mixture was poured into deionized water $(25 \mathrm{ml})$. The precipitate was filtered off and washed with water $(3 \times 3 \mathrm{ml}), 5 \% \mathrm{MeOH} / \mathrm{DCM}(2 \times 3$ $\mathrm{ml})$ and $\mathrm{ACN}(3 \times 3 \mathrm{ml})$. The crude product was purified by column chromatography on $30 \mathrm{~g}$ of silica gel using $3 \%$ $\mathrm{MeOH} / \mathrm{DCM}$ as an eluent. The progress of the chromatographic separation was monitored with TLC using $60 \%$ EtOAc/Hexane as an eluent. Fractions containing pure product were combined and evaporated to yield $0.032 \mathrm{~g}(36 \%)$ of the desired product as brown solid.

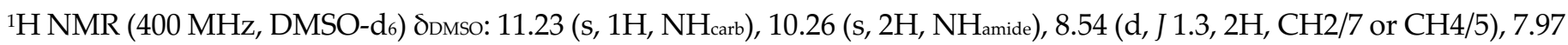
(d, J 1.12, 2H, CH2/7 or CH4/5), 2.38 (s, $\left.4 \mathrm{H}, \mathrm{CH}_{2}\right) 1.10$ (s, 18H, t-Bu); ${ }^{13} \mathrm{C}$ NMR (101 MHz, DMSO-d6) Sdmso: 170.77, 134.56, 124.36, 123.71, 122.45, 122.15, 119.60, 102.26, 49.03, 30.98, 29.64; HR MS (ESI): $\mathrm{m} / z$ calcd. for $\mathrm{C}_{26} \mathrm{H}_{29} \mathrm{~N}_{5} \mathrm{O}_{2} \mathrm{Na}[\mathrm{M}+\mathrm{Na}]^{+}$: 466.2213, found: 466.2219 .

\subsubsection{Synthesis of Receptor 4}

Receptor 4 was obtained in two steps from commercially available 1,3,6,8-tetranitrocarbazole.

\section{Synthesis of 1,8-diamino-3,6-dinitrocarbazole}

Prior to the synthesis, the commercially available 1,3,6,8-tetranitrocarbazole (wetted with ca. 40\% water) was dried in a vacuum desiccator over $\mathrm{KOH}$ to a constant mass.

To a $25 \mathrm{ml}$ round-bottom two-neck flask equipped with a magnetic stirrer, 1,3,6,8-tetranitrocarbazole $(0.200 \mathrm{~g}, 0.58$ $\mathrm{mmol})$ and anhydrous EtOH $(10 \mathrm{ml})$ were added. The flask was equipped with a reflux condenser connected to a checkvalve bubbler, the side neck was sealed with a septum and argon was bubbled through the mixture for 10 minutes with slow stirring. After this time $\mathrm{FeSO}_{4} \cdot 7 \mathrm{H}_{2} \mathrm{O}(10 \mathrm{mg}, 0.036 \mathrm{mmol})$ was added. Argon was bubbled through the mixture for additional $15 \mathrm{~min}$. Then, in the flow of argon, hydrazine monohydrate $\left(98 \% \mathrm{NH}_{2} \mathrm{NH}_{2} \cdot \mathrm{H}_{2} \mathrm{O}, 1.20 \mathrm{ml}, 25 \mathrm{mmol}\right)$ was added dropwise. The mixture was heated to reflux and stirred for $20 \mathrm{~h}$. After cooling to RT, the precipitate was filtered off, sonicated with $\mathrm{MeOH}$ for 10 min and filtered off once again. Vacuum drying yielded product as dark brown powder $(0.130 \mathrm{~g}, 78 \%)$. The product was used for the subsequent reaction without any additional purification.

${ }^{1} \mathrm{H}$ NMR (400 MHz, DMSO-d 6 ) dxmso: 11.71 (s, 1H, NHcarb), 8.58 (s, 2H, CH4/5 or CH2/7), 7.62 (s, 2H, CH4/5 or CH2/7), 5.76 (s, 4H, NH2); ${ }^{13} \mathrm{C}$ NMR (101 MHz, DMSO-d6) DDMso: 142.07, 134.70, 133.05, 122.68, 106.74, 103.80; HR MS (ESI): $\mathrm{m} / \mathrm{z}$ calcd. for $\mathrm{C}_{12} \mathrm{H}_{8} \mathrm{~N}_{5} \mathrm{O}_{4}[\mathrm{M}-\mathrm{H}]-:$ : 286.0576, found: 286.0565 . 
Synthesis of receptor 4

A $25 \mathrm{ml}$ round-bottom flask was dried with a heat gun (set to ca. $500^{\circ} \mathrm{C}$ ) for 10 minutes, and then cooled down to $\mathrm{RT}$ in a desiccator. To the flask, 1,8-diamino-3,6-dinitrocarbazole $(0.190 \mathrm{~g}, 1.00 \mathrm{mmol})$ was added, followed by a magnetic stirrer. The neck of the flask was sealed with septum and the flask was filled with argon by three pump-thaw cycles. Anhydrous dimethylacetamide $(10 \mathrm{ml})$ was added via a syringe followed by the addition of 3,3-dimethylbutyryl chloride $(0.420 \mathrm{ml}, 3.00 \mathrm{mmol})$. The reaction was stirred at RT for $20 \mathrm{~h}$. After this time, the reaction mixture was poured into deionized water $(100 \mathrm{ml})$, cooled down in a refrigerator for $20 \mathrm{~min}$ and the participate was filtered off and washed with water $(3 \times 3 \mathrm{ml})$ and $\mathrm{MeOH}(2 \times 3 \mathrm{ml})$. Slightly contaminated product was suspended in acetone $(80 \mathrm{ml})$, sonicated for $10 \mathrm{~min}$ and filtered off. Vacuum drying yielded pure product as yellow powder $(0.280 \mathrm{~g}, 58 \%)$.

${ }^{1} \mathrm{H}$ NMR (400 MHz, DMSO-d6) dDmso: 11.49 (s, 1H, NHcarb), 10.38 (s, 2H, NHamide), 9.28 (d, J 2.2, 2H, CH4/5), 8.55 (d, J 2.1, 2H, CH2/7), $2.40\left(\mathrm{~s}, 4 \mathrm{H}, \mathrm{CH}_{2}\right) 1.11$ (s, 18H, $t$-Bu); ${ }^{13} \mathrm{C}$ NMR (101 MHz, DMSO-d6) סdmso: 170.90, 141.17, 136.07, 123.85, 123.77, 114.54, 114.53, 49.04, 30.99, 29.62; HR MS (ESI): $\mathrm{m} / \mathrm{z}$ calcd. for $\mathrm{C}_{24} \mathrm{H}_{28} \mathrm{~N}_{5} \mathrm{O} 6 \mathrm{Na}$ [M-H]-: 482.2040, found: 482.2038; Elemental Analysis calcd. for $\mathrm{C}_{24} \mathrm{H}_{29} \mathrm{~N}_{5} \mathrm{O}_{6}: \mathrm{C}, 59.62 ; \mathrm{H}, 6.05 ; \mathrm{N}, 14.48$; found: $\mathrm{C}, 59.28 ; \mathrm{H}, 6.07 ; \mathrm{N}, 14.21$.

\subsection{Binding Studies}

\subsubsection{Typical procedure for ${ }^{1} \mathrm{H}$ NMR titration}

All the reagents were weighted separately on an analytical balance (readability $0.01 \mathrm{mg}$ ) in screw-capped vials sealed with Teflon-covered septa. DMSO- $\mathrm{d}_{6}+0.5 \% \mathrm{H}_{2} \mathrm{O}(\mathrm{w} / \mathrm{w})$ mixture was prepared and used as a solvent. All the solvents/solutions manipulations were done using gas-tight Hamilton glass syringes. Titrant was prepared by dissolving $\mathrm{TBACl}$ in the solution of the receptor, in order to avoid dilution of the receptor during titration. To a solution of host $(600 \mu \mathrm{l}, 0.01 \mathrm{M})$ in a septum-sealed screw-capped NMR tube sealed with Teflon-covered septum, appropriate aliquots of titrant (up to 10 equiv., $0.3 \mathrm{M}$, dissolved in the solution of host to avoid dilution) were added with a $25 \mu$ l gas-tight microsyringe. ${ }^{1} \mathrm{H}$ NMR spectrum was recorded after each addition of the salt, and the temperature inside the NMR probe was kept constant at $25^{\circ} \mathrm{C}$. Association constants were calculated from changes in the chemical shifts of the most affected protons of the ligands, as indicated in each case below.

\subsubsection{Typical procedure for UV-Vis titration}

All the reagents were weighted separately on an analytical balance (readability $0.01 \mathrm{mg}$ ) in screw-capped vials sealed with Teflon-covered septa. DMSO- $\mathrm{d}_{6}+0.5 \% \mathrm{H}_{2} \mathrm{O}(\mathrm{w} / \mathrm{w})$ mixture was prepared and used as a solvent. All the solvents/solutions manipulations were done using gas-tight Hamilton glass syringes. Titrants were prepared by dissolving an appropriate amount of TBA salt in the solution of the receptor, in order to avoid dilution of the receptor during titration.

Typically, to a solution of host $\left(3 \mathrm{ml}, 10^{-4} \mathrm{M}\right)$ in a septum-sealed screw-cap precision cell made of SUPRASIL Quartz (light path: $10 \mathrm{~mm}$ ) appropriate aliquots of titrant $\left(7.5 \times 10^{-3} \mathrm{M}\right.$, dissolved in the solution of host to avoid dilution) were added with a $25 \mu \mathrm{l}$ gas-tight microsyringe. The absorption spectra were recorded between 280 and $600 \mathrm{~nm}$ after each addition of the salt at $25^{\circ} \mathrm{C}$. Association constants were calculated from changes in absorbance at fixed wavelengths, as detailed below.

\subsubsection{Data fitting}

The association constants were determined from $\mathrm{NH}_{\text {amide }}$ and $\mathrm{NH}_{\text {carb. }}$ resonances using global fitting analysis. This was performed using the BindFit web applet and the 1:1 binding model (Nelder-Mead method, 'Subtract initial values' $=\mathrm{ON})$. In all cases, the 1:1 model gave very good fit to the data, as well as reasonable values of binding constants.

The UV-Vis titration data were fitted with HypSpec software. Association constants and molar absorption coefficients of complexes were set as free parameters for fitting. Logarithms of association constants were averaged using arithmetic mean from at least two separate experiments.

\subsection{Self-dissociation studies}

\subsubsection{Typical procedure for trifluoromethanesulfonic acid titration}

All the reagents were weighted separately on an analytical balance (readability $0.01 \mathrm{mg}$ ) in screw-capped vials sealed with Teflon-covered septa. DMSO- $\mathrm{d}_{6}+0.5 \% \mathrm{H}_{2} \mathrm{O}(\mathrm{w} / \mathrm{w})$ mixture was prepared and used as a solvent. All the solvents/solutions manipulations were done using gas-tight Hamilton glass syringes. Titrant was prepared by 
dissolving trifluoromethanesulfonic acid $\mathrm{TfOH}$ in the solution of the receptor (in order to avoid dilution of the receptor during titration).

Typical, to a solution of host $\left(3 \mathrm{ml}, 10^{-4} \mathrm{M}\right)$ in a septum-sealed screw-cap precision cell made of SUPRASIL Quartz (light path: $10 \mathrm{~mm}$ ) appropriate aliquots of titrant $\left(7.5 \times 10^{-3} \mathrm{M}\right.$, dissolved in the solution of host to avoid dilution) were added with a $25 \mu \mathrm{l}$ gas-tight microsyringe. The absorption spectra were recorded between 280 and $600 \mathrm{~nm}$ after each addition of the acid at $25^{\circ} \mathrm{C}$.

\subsection{Single crystal X-ray diffraction analysis}

Good quality single crystals for X-ray structural investigations were obtained by slow diffusion of pentane into dichloroethane solutions containing receptors 3 or 4 and $\mathrm{Ph} 4 \mathrm{PCl}$. Diffraction data were collected on the Agilent Technologies SuperNova Dual Source with the MoK $\alpha$ radiation $(\lambda=0.71073 \AA)$. The lattice parameters were obtained by least-squares fit to the optimized setting angles of the reflections collected by using the CrysAlis CCD software [38]. Data were reduced using the CrysAlis RED program [38]. The gaussian numerical absorption correction using a multifaceted crystal model implemented in SCALE3 ABSPACK scaling algorithm, was applied [38]. Using Olex2 [39], the structure was solved with the ShelXT [40] structure solution program using Intrinsic Phasing and refined with the ShelX1 [41] refinement package using Least Squares minimisation. All H-atoms were positioned geometrically. The crystallographic data are summarized in Table S1. The values of bond lengths and valence angles are given in Tables S2-S3.

Supplementary Materials: The following are available online: Figure S1: ${ }^{1} \mathrm{H}$ NMR spectrum of 3,6-dicyjano-1,8-dinitrocarbazole in DMSO-d6; Figure S2: ${ }^{13} \mathrm{C}$ NMR spectrum of 3,6-dicyjano-1,8-dinitrocarbazole in DMSO-d6; Figure S3: ${ }^{1} \mathrm{H}$ NMR spectrum of 1,8-diamino-3,6-dicyjanocarbazole in DMSO-d6; Figure S4: ${ }^{13} \mathrm{C}$ NMR spectrum of 1,8-diamino-3,6-dicyjanocarbazole in DMSO-d6; Figure S5: ${ }^{1} \mathrm{H}$ NMR spectrum of 3 in DMSO-d6; Figure S6: ${ }^{13} \mathrm{C}$ NMR spectrum of 3 in DMSO-d6; Figure S7: ${ }^{1} \mathrm{H}$ NMR spectrum of 1,8-diamino3,6-dinitrocarbazole in DMSO-d6; Figure S8: ${ }^{13} \mathrm{C}$ NMR spectrum of 1,8-diamino-3,6-dinitrocarbazole in DMSO-d6; Figure S9: ${ }^{1} \mathrm{H}$ NMR spectrum of 4 in DMSO-d6; Figure S10: ${ }^{13} \mathrm{C}$ NMR spectrum of 4 in DMSO-d6; Figure S11: ${ }^{1} \mathrm{H}$ ROESY spectrum of 4 in DMSO-d 6 ; Scheme S1: Amide groups conformations in 4; ${ }^{1} \mathrm{H}$ NMR spectra of titration with TBACl in DMSO-d $6+0.5 \% \mathrm{H}_{2} \mathrm{O}$, raw data, titration curves obtained from chemical shifts of $\mathrm{NH}_{\text {carb. }}$ and $\mathrm{NH}_{\text {amide }}$ protons; UV-Vis spectra from titrations with TBA salts in DMSO- $\mathrm{d}_{6}+$ $0.5 \% \mathrm{H}_{2} \mathrm{O}$, raw data; $\mathrm{UV}$-Vis spectra of self-dissociation reversing titration with $\mathrm{TfOH}$ in DMSO- $\mathrm{d}_{6}+0.5 \% \mathrm{H}_{2} \mathrm{O}$, titration curves; crystallographic data and refinement details. Crystallographic data for the structures in this paper have been deposited with the Cambridge Crystallographic Data Centre as supplementary publication number CCDC 2074344 and 2074345. Copies of the data can be obtained, free of charge, on application to CCDC [e- mail: deposit@ccdc.cam.ac.uk, website: www.ccdc.cam.ac.uk].

Funding: This work was supported by the National Science Centre, Poland (OPUS grant 2018/31/B/ST5/02085 to M.J.C.) This study was carried out at the Biological and Chemical Research Centre, University of Warsaw, established within a project co-financed by the European Union through the European Regional Development Fund under the Operational Programme Innovative Economy 2007-2013.

Acknowledgments: We thank dr Szymon Sutuła from the Core Facility for Crystallography and Biophysics for the excellent crystallographic service he provides.

\section{References}

1. Busschaert, N.; Caltagirone, C.; Rossom, W. Van.; Gale, P. A. Applications of Supramolecular Anion Recognition. Chem. Rev., 2015, 115, 8038-8155. DOI: 10.1021/acs.chemrev.5b00099.

2. Gunnlaugsson, T.; Kruger, P. E.; Jensen, P.; Tierney, J.; Ali, H. D. P.; Hussey, G. M. Colorimetric “Naked Eye” Sensing of Anions in Aqueous Solution. J. Org. Chem., 2005, 70(26), 10875-8. DOI: 10.1021/jo0520487.

3. Hiscock, J. R.; Caltagirone, C.; Light, M. E.; Hursthouse, M. B.; Gale, P. A. Fluorescent carbazolylurea anion receptors. Org. Biomol. Chem., 2009, 7, 1781-1783. DOI: 10.1039/B900178F.

4. Zapata, F.; Caballero, A.; White, N. G.; Claridge, T. D. W.; Costa, P. J.; Félix, V.; Beer, P. D. Fluorescent Charge-Assisted Halogen-Bonding Macrocyclic Halo-Imidazolium Receptors for Anion Recognition and Sensing in Aqueous Media. J. Am. Chem. Soc., 2012, 134, 28, 11533-11541. DOI: 10.1021/ja302213r.

5. Al-Sayah, M. H.; Abdalla, A. M.; Shehab, M. K. A dansyl-based optical probe for detection of singly and doubly charged anions. Supramol. Chemistry, 2016, 28, 224-230, DOI: 10.1080/10610278.2015.1091456. 
6. Casula, A.; Bazzicalupi, C.; Bettoschi, A.; Cadoni, E.; Coles, S. J.; Horton, P. N.; Isaia, F.; Lippolis, V.; Mapp, L. K.; Marini, G. M.; Montis, R.; Scorciapino, M. A., Caltagirone, C. Fluorescent asymmetric bis-ureas for pyrophosphate recognition in pure water. Dalton Trans., 2016, 45, 3078-3085. DOI: 10.1039/c5dt04497a.

7. Navarro-García, E.; Velasco, M. D.; Zapata, F.; Bauzá, A.; Frontera, A.; Ramírez de Arellano, C.; Caballero, A. Exploiting 1,4-naphthoquinone and 3-iodo-1,4-naphthoquinone motifs as anion binding sites by hydrogen or halogenbonding interactions. Dalton Trans., 2019, 48, 11813-11821. DOI: 10.1039/C9DT02012H.

8. Gale P. A.; Caltagirone, C. Fluorescent and colorimetric sensors for anionic species. Coord. Chem. Rev., 2018, 354, 2-27. DOI: 10.1016/j.ccr.2017.05.003.

9. McNaughton, D. A.; Fares, M.; Picci, G.; Gale, P. A.; Caltagirone, C. Advances in fluorescent and colorimetric sensors for anionic species. Coordination Chemistry Reviews, 2021, 427, 213573. DOI: 10.1016/j.ccr.2020.213573.

10. Chmielewski, M. J.; Charon, M.; Jurczak, J. 1,8-Diamino-3,6-dichlorocarbazole: A Promising Building Block for Anion Receptors. Org. Lett. 2004, 6, 3501-3504. DOI: 10.1021/o1048661e.

11. Piątek, P.; Lynch, V. M.; Sessler, L. J.; Calix[4]pyrrole[2]carbazole: A New Kind of Expanded Calixpyrrole. J. Am. Chem. Soc., 2004, 126, 49, 16073-16076. DOI: 10.1021/ja045218q.

12. Thangadurai, T. D.; Singh, N. J.; Hwang, I.-C.; Lee,J. W.; Chandran, R. P.; Kim. K. S. 2-Dimensional Analytic Approach for Anion Differentiation with Chromofluorogenic Receptors. J. Org. Chem. 2007, 72, 14, 5461-5464. DOI: 10.1021/jo070791o.

13. Gross, D. E.; Vinay Mikkilineni, Vincent M. Lynch, and Jonathan L. Sessler, Bis-amidopyrrolyl Receptors Based on Anthracene and Carbazole. Supramol Chem., 2010, 22, 135-141. DOI: 10.1080/10610270903304434.

14. Hiscock, J. R.; Gale, P. A.; Caltagirone , C.; Hursthouse, M. B.; Light, M. E. Fluorescent carbazolylurea- and carbazolylthiourea-based anion receptors and sensors. Supramol. Chem., 2010, 22, 647-652. DOI:10.1080/10610271003637087

15. Ahmed, N.; Geronimo, I.; Hwang, I.-C.; Singh, J.; Kim. K. S. cyclo-Bis(urea-3,6-dichlorocarbazole) as a Chromogenic and Fluorogenic Receptor for Anions and a Selective Sensor of Zinc and Copper Cations. Chem. Eur. J. 2011, 17, 85428548. DOI: 10.1002/chem.201100243.

16. Yang, Y.; Xue, M.; Marshall, L. J.; de Mendoza, J. Hydrogen-Bonded Cyclic Tetramers Based on Ureidopyrimidinones Attached to a 3,6-Carbazolyl Spacer. Org. Lett. 2011, 13, 12, 3186-3189. DOI: 10.1021/ol200946b.

17. Fuentes de Arriba, A. L.;Turiel, M. G.; Simón, L.; Sanz, F.; Boyero, J. F.; Muñiz, F. M.; Morána, J. R.; Alcázar, V. Sulfonamide carbazole receptors for anion recognition. Org. Biomol. Chem., 2011, 9, 8321-8327. DOI: 10.1039/C1OB06126G.

18. Sanchez, G.; Espinosa, A.; Curiel, D.; Tarraga, A.; Molina, P. Bis(carbazolyl)ureas as Selective Receptors for the Recognition of Hydrogenpyrophosphate in Aqueous Media. J. Org. Chem., 2013, 78, 19, 9725-9737. DOI: 10.1021/jo401430d.

19. Bąk, K. M.; Chmielewski, M. J. Sulfate templated assembly of neutral receptors in aqueous DMSO - orthogonal versus biplane structures. Chem. Commun. 2014, 50, 1305-1308. DOI: 10.1039/C3CC48463G.

20. Bąk, K. M.; Masłowska, K.; Chmielewski, M. J. Selective turn-on fluorescence sensing of sulfate in aqueous-organic mixtures by an uncharged bis(diamidocarbazole) receptor. Org. Biomol. Chem., 2017, 15, 5968-5975. DOI: 10.1039/C7OB01358B.

21. Martin, K.; Nõges, J.; Haav, K.; Kadam, S. A.; Pung, A.; Leito, I. Exploring Selectivity of 22 Acyclic Urea-, Carbazoleand Indolocarbazole- Based Receptors towards 11 Monocarboxylates. Eur. J. Org. Chem. 2017, 35, 5231-5237. DOI: 10.1002/ejoc.201700931.

22. Bakk, K. M.; Chabuda, K.; Montes, H.; Quesada, R.; Chmielewski, M. J. 1,8-Diamidocarbazoles: an easily tuneable family of fluorescent anion sensors and transporters. Org. Biomol. Chem. 2018, 16, 5188-5196. DOI: 10.1039/C8OB01031E. 
23. Rüütel, A.; Yrjänä, V.; Kadam, S. A.; Saar, I.; Ilisson, M.; Darnell, A.; Haav, K.; Haljasorg, T.; Toom, L.; Bobacka, J.; Leito, I. Design, synthesis and application of carbazole macrocycles in anion sensors. Beilstein J Org Chem., 2020, 16, 1901-1914. DOI: 10.3762/bjoc.16.157.

24. Yrjänä, V.; Saar, I.; Ilisson, M.; Kadam, S. A.; Leito, I.; Bobacka, J. Potentiometric Carboxylate Sensors Based on Carbazole-Derived Acyclic and Macrocyclic Ionophores. Chemosensors, 2021, 9, 4. DOI: 10.3390/chemosensors9010004.

25. Bąk, K. M.; Kolck, B. van.; Maslowska-Jarzyna, K.; Papadopoulou, P.; Kros, A.; Chmielewski, M. J. Oxyanion transport across lipid bilayers: direct measurements in large and giant unilamellar vesicles. Chem. Commun. 2020, 56, 4910-4913. DOI: 10.1039/C9CC09888G.

26. Pomorski, R.; García-Valverde, M.; Quesada, R.; Chmielewski, M. J. Transmembrane anion transport promoted by thioamides. RSC Advances, accepted.

27. Muzık, F.; Allan, Z.; Poskocil, J. Derivate des Carbazols IV. Herstellung von 3,6-Dichlor-1,8-diaminocarbazol. Collect. Czech. Chem. Commun., 1958, 23, 770-772. DOI: 10.1135/cccc19580770.

28. Fedorczyk, A.; Pomorski, R.; Chmielewski, M. J.; Ratajczak, J.; Kaszkur, Z.; Skompska, M. Bimetallic Au@Pt nanoparticles dispersed in conducting polymer-A catalyst of enhanced activity towards formic acid electrooxidation. Electrochim. Acta, 2017, 246, 1029-1041. DOI: 10.1016/j.electacta.2017.06.

29. Weselinski, L. J.; Luebke, R.; Eddaoudi, M. A Convenient Preparation of 9H-Carbazole-3,6-dicarbonitrile and 9HCarbazole-3,6-dicarboxylic Acid. Synthesis, 2014, 46, 596-599. DOI: 10.1055/s-0033-1340557.

30. Andreozzi, R.; Marotta, R.; Sanchirico, R. Thermal decomposition of acetic anhydride-nitric acid mixtures. Journal of Hazardous Materials, 2002, 90, 111-121. DOI: 10.1016/S0304-3894(01)00356-9.

31. Sharma, U.; Verma, P. K.; Kumar, N.; Kumar, V.; Bala, M.; Singh, B. Phosphane-Free Green Protocol for Selective Nitro Reduction with an Iron-Based Catalyst. Chem. Eur. J., 2011, 17, 5903-5907. DOI: 10.1002/chem.201003621.

32. Bindfit-Fit Data to 1:1 Host-Guest Equilibria. Available online: http://supramolecular.org (accessed on 16 March 2021).

33. Zhanga, Z.; Schreiner, P. R. (Thio)urea organocatalysis - What can be learnt from anion recognition? Chem. Soc. Rev., 2009, 38, 1187-1198. DOI: 10.1039/B801793J.

34. Elmes; R. B. P.; Busschaert, N.; Czech, D. D.; Gale, P. A.; Jolliffe, K. A. pH switchable anion transport by an oxothiosquaramide. Chem. Commun., 2015, 51, 10107-10110. DOI: 10.1039/c5cc03625a.

35. Saha, A.; Akhtar, N.; Kumar, V.; Kumar, S.; Srivastava, H. K.; Kumarb, S.; Manna, D. pH-Regulated anion transport activities of bis (iminourea) derivatives across the cell and vesicle membrane. Org. Biomol. Chem., 2019, 17, 5779-5788. DOI: $10.1039 / \mathrm{c} 90 \mathrm{ob} 00650 \mathrm{~h}$.

36. Howe, E. N. W.; Busschaert, N.; Wu, X.; Berry, S. N.; Ho, J.; Light, M. E.; Czech, D. D.; Klein, H. A.; Kitchen, J. A.; Gale, P. A. pH-Regulated Nonelectrogenic Anion Transport by Phenylthiosemicarbazones. J. Am. Chem. Soc., 2016, 138, 8301-8308. DOI: 10.1021/jacs.6b04656.

37. Busschaert, N.; Elmes, R. B. P.; Czech, D. D.; Wu, X.; Kirby, I. L.; Peck, E. M.; Hendzel, K. D.; Shaw, S. K.; Chan, B.; Smith, B. D.; Jolliffe K. A.; Gale, P. A. Thiosquaramides: pH switchable anion transporters. Chem. Sci., 2014, 5, 3617-3626. DOI: $10.1039 / \mathrm{c} 4 \mathrm{sc} 01629 \mathrm{~g}$.

38. CrysAlis CCD and CrysAlis RED; Oxford Diffraction Ltd: Yarnton, 2008.

39. Dolomanov, O. V.; Bourhis, L .J.; Gildea, R. J.; Howard, J.A.K.; Puschmann, H. J. Appl. Cryst. 2009, 42, 339-341.

40. Sheldrick, G. M. Acta Cryst. A71, 2015, 3-8.

41. Sheldrick, G. M. Acta Cryst. C71, 2015, 3-8. 


\section{Supporting Information}

\section{Carbazole-based colorimetric anion sensors}

Krystyna Maslowska-Jarzyna, Maria L. Korczak, Jakub Wagner and Michał J. Chmielewski* Faculty of Chemistry, Biological and Chemical Research Centre, University of Warsaw Żwirki i Wigury 101, 02-089 Warszawa, Poland

E-mail:mchmielewski@chem.uw.edu.pl 


\section{Contents}

$1 \quad$ NMR spectra. 3

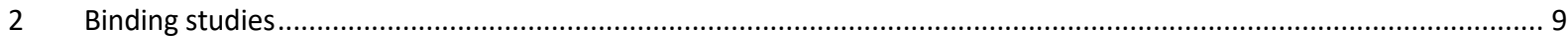

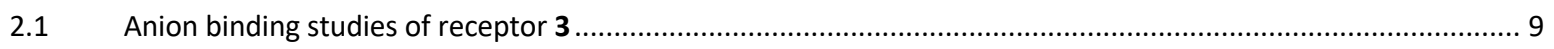

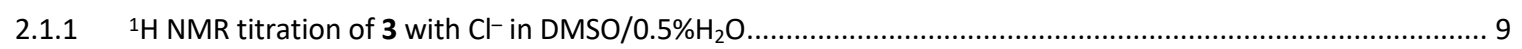

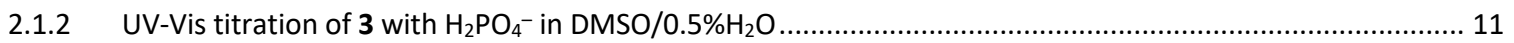

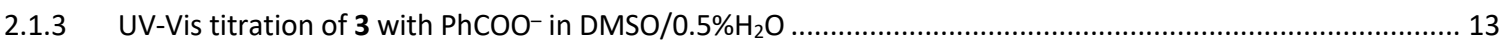

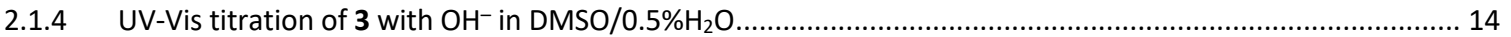

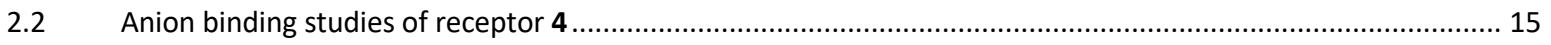

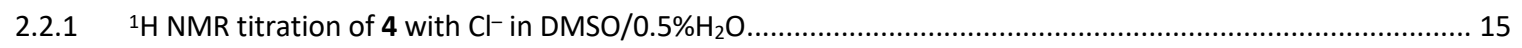

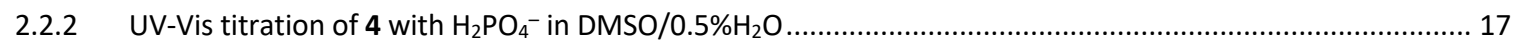

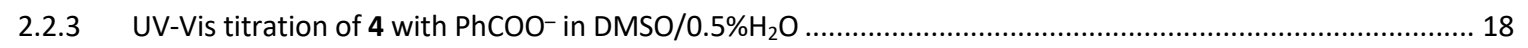

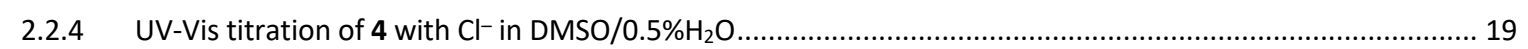

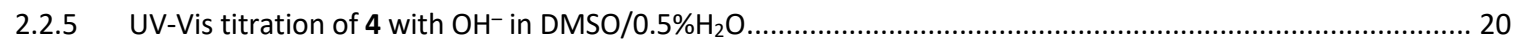

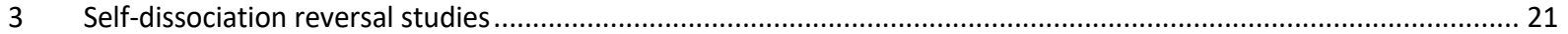

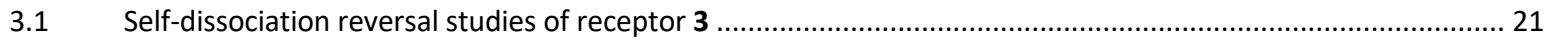

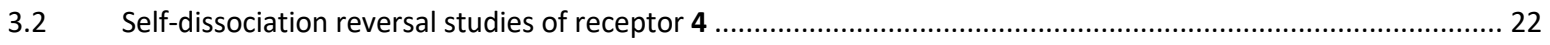

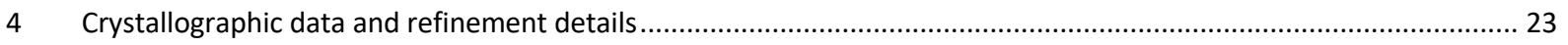

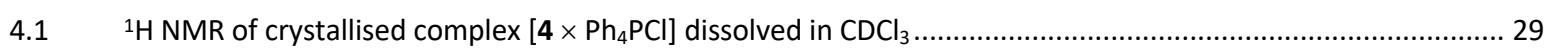




\section{NMR spectra}

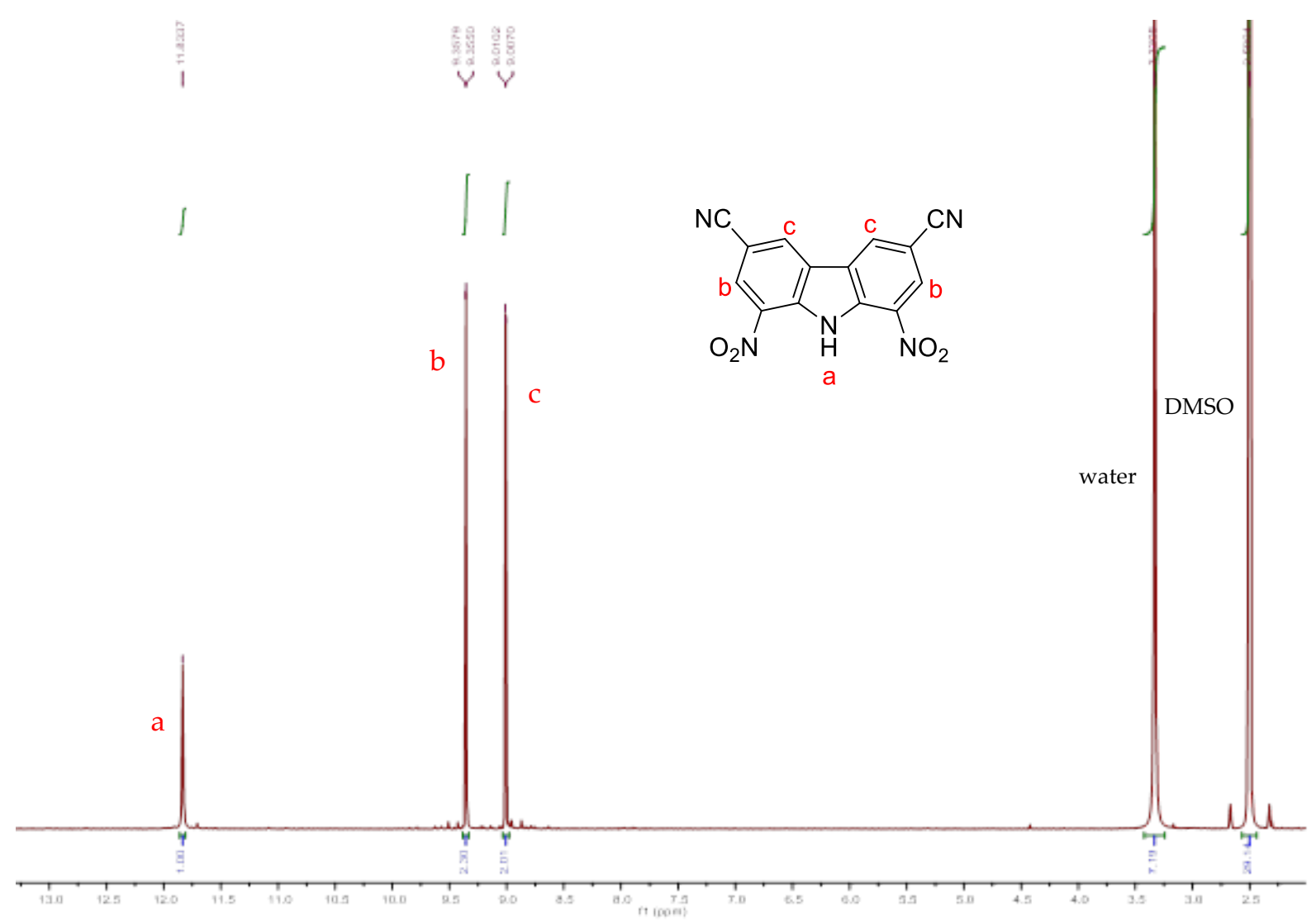

Figure S1. ${ }^{1} \mathrm{H}$ NMR spectrum of 3,6-dicyjano-1,8-dinitrocarbazole in DMSO- $d_{6}$.

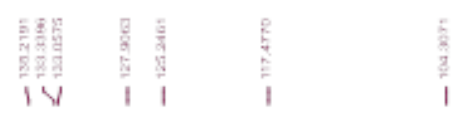

DMSO
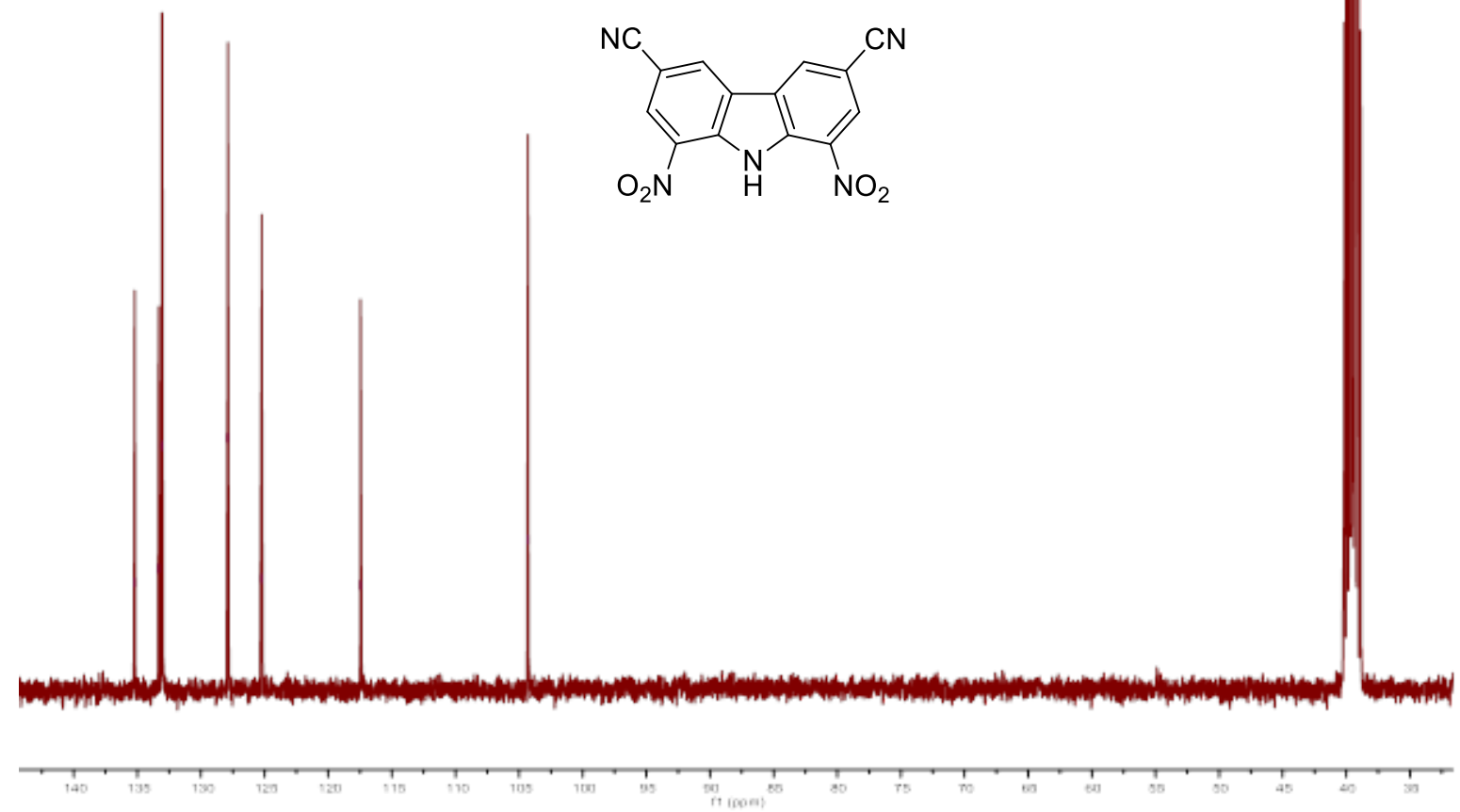

Figure S2. ${ }^{13} \mathrm{C}$ NMR spectrum of 3,6-dicyjano-1,8-dinitrocarbazole in DMSO- $d_{6}$. 


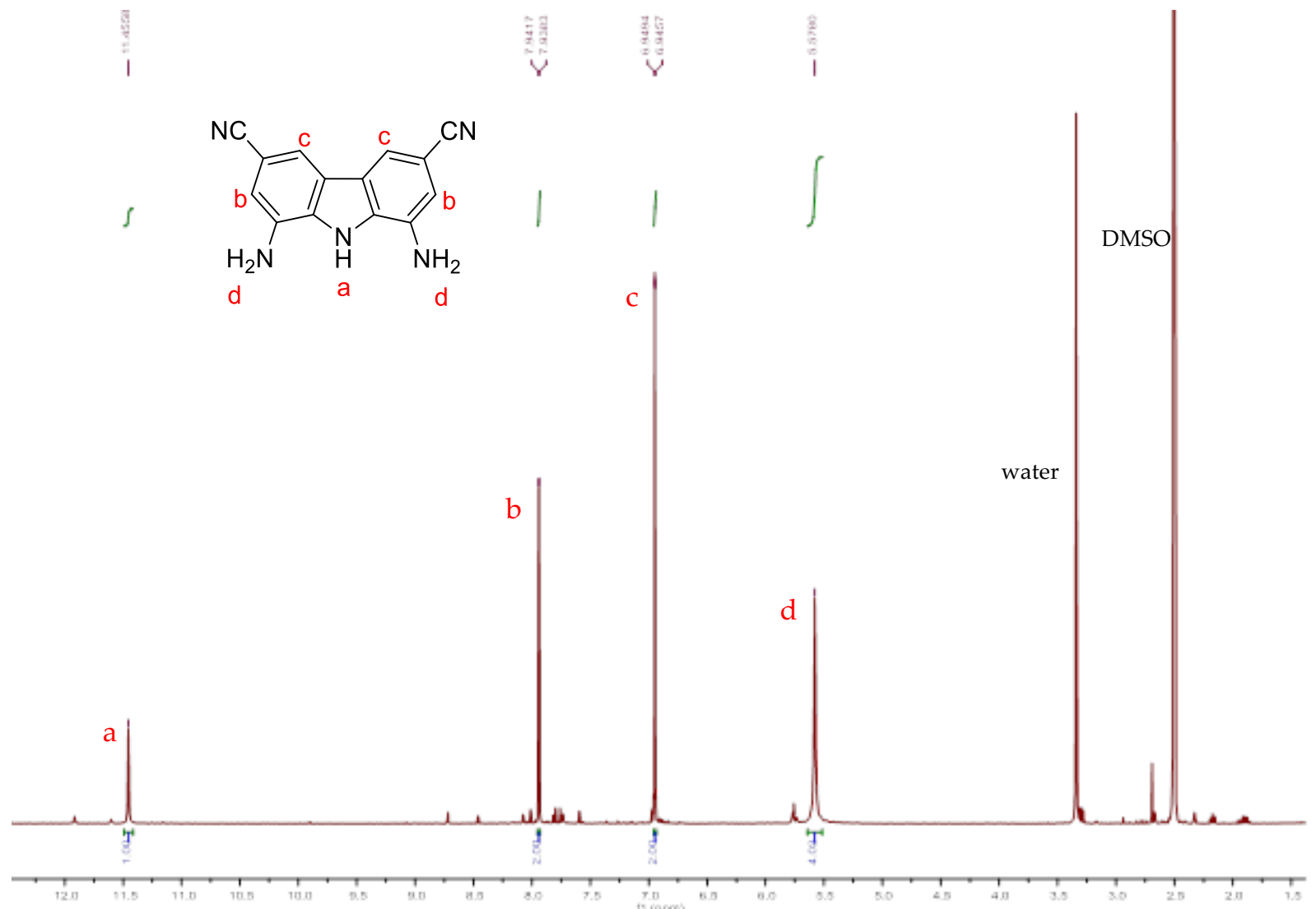

Figure S3. ${ }^{1} \mathrm{H}$ NMR spectrum of 1,8-diamino-3,6-dicyjanocarbazole in DMSO- $d_{6}$.
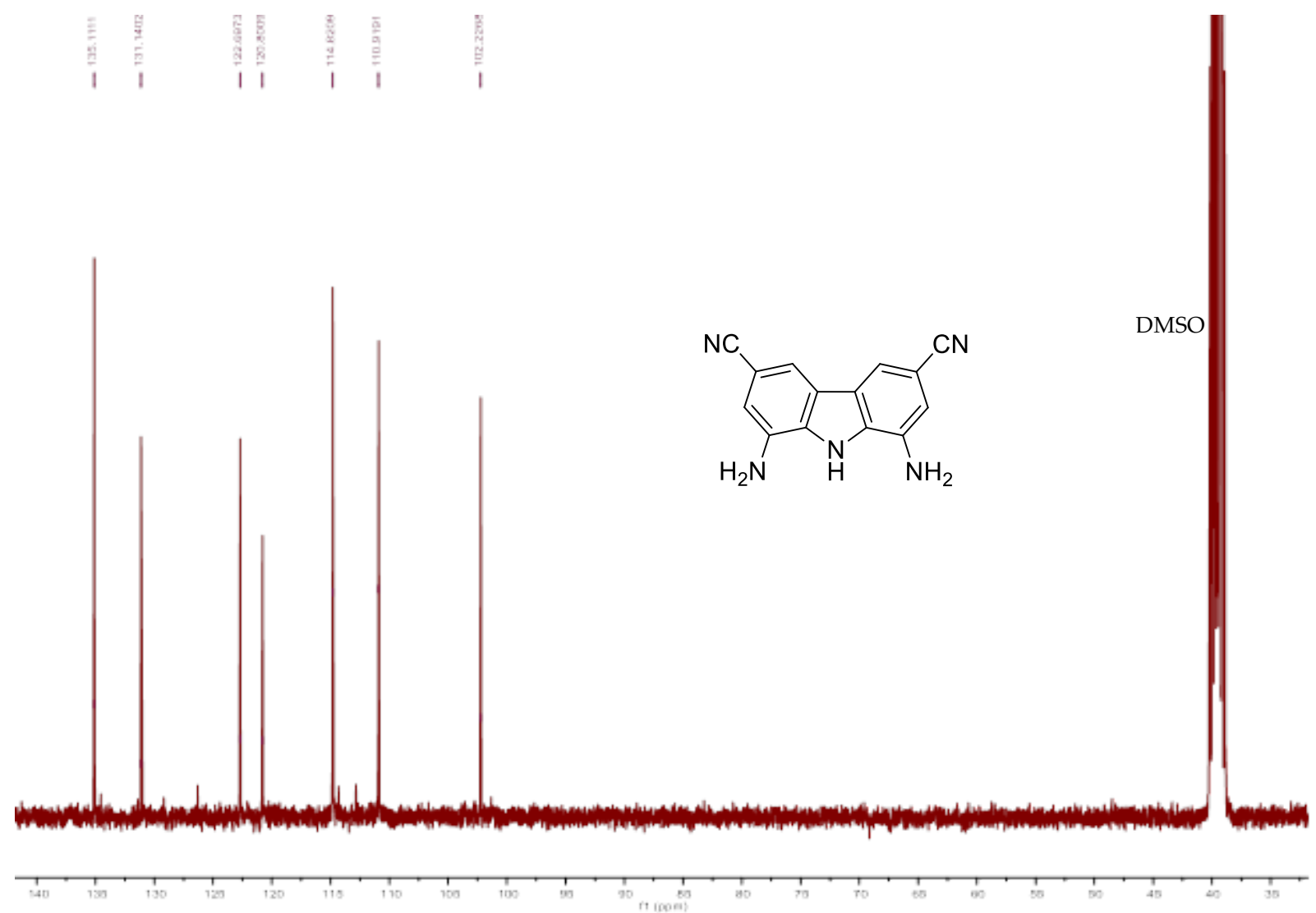

Figure S4. ${ }^{13} \mathrm{C}$ NMR spectrum of 1,8-diamino-3,6-dicyjanocarbazole in DMSO- $d_{6}$. 


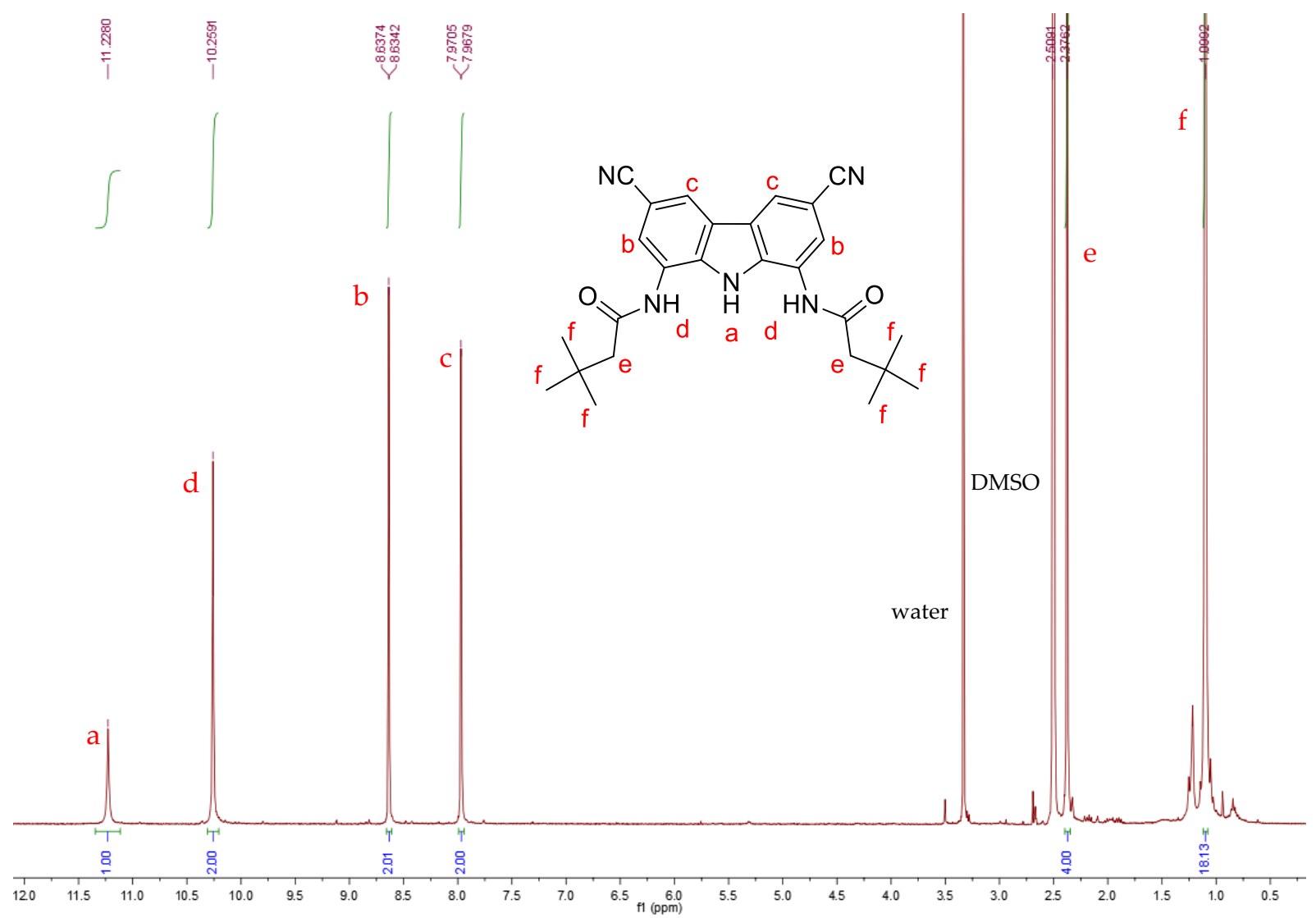

Figure S5. ${ }^{1} \mathrm{H}$ NMR spectrum of 3 in DMSO- $d_{6}$.
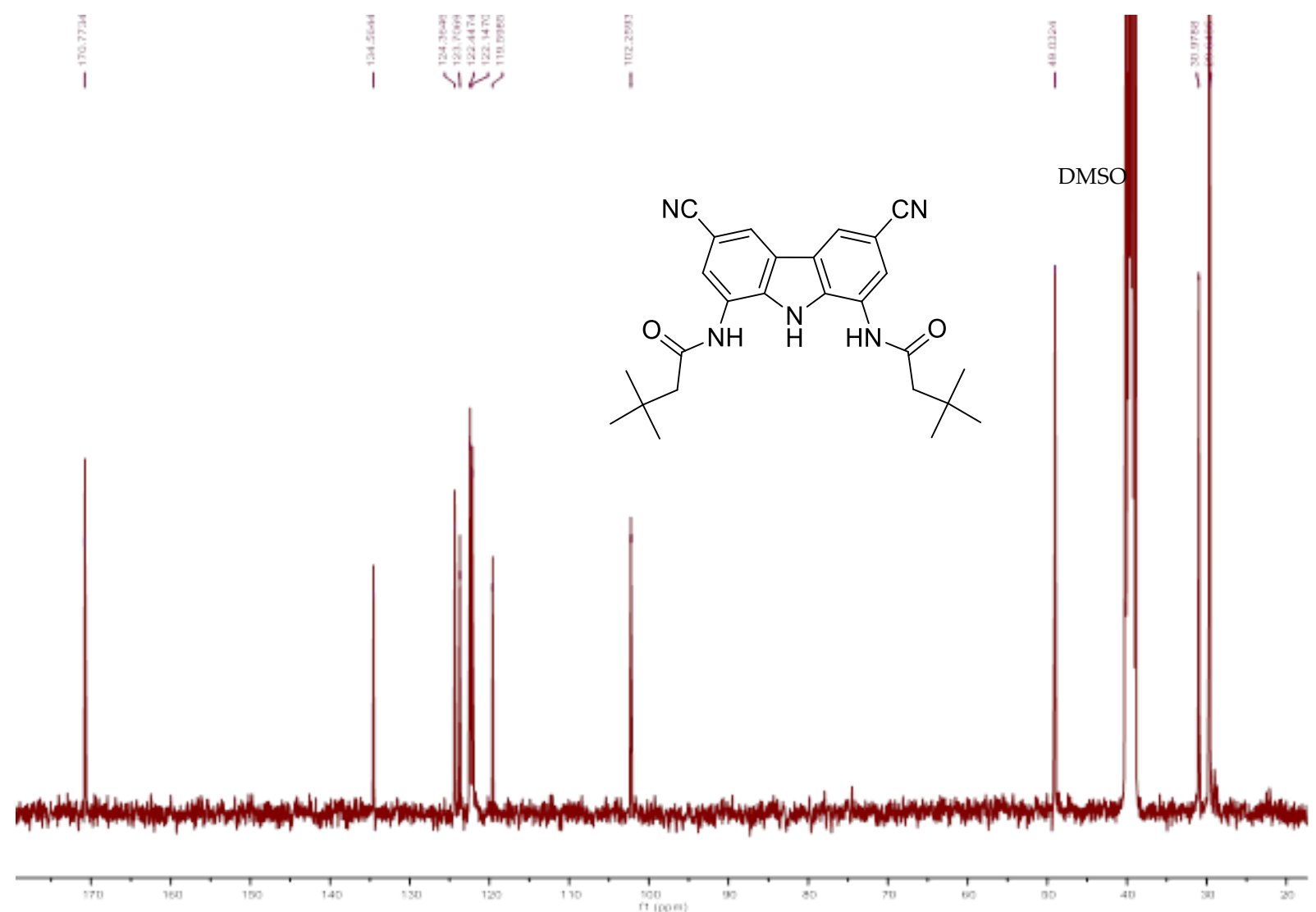

DMSO

Figure S6. ${ }^{13} \mathrm{C}$ NMR spectrum of $\mathbf{3}$ in DMSO- $d_{6}$. 


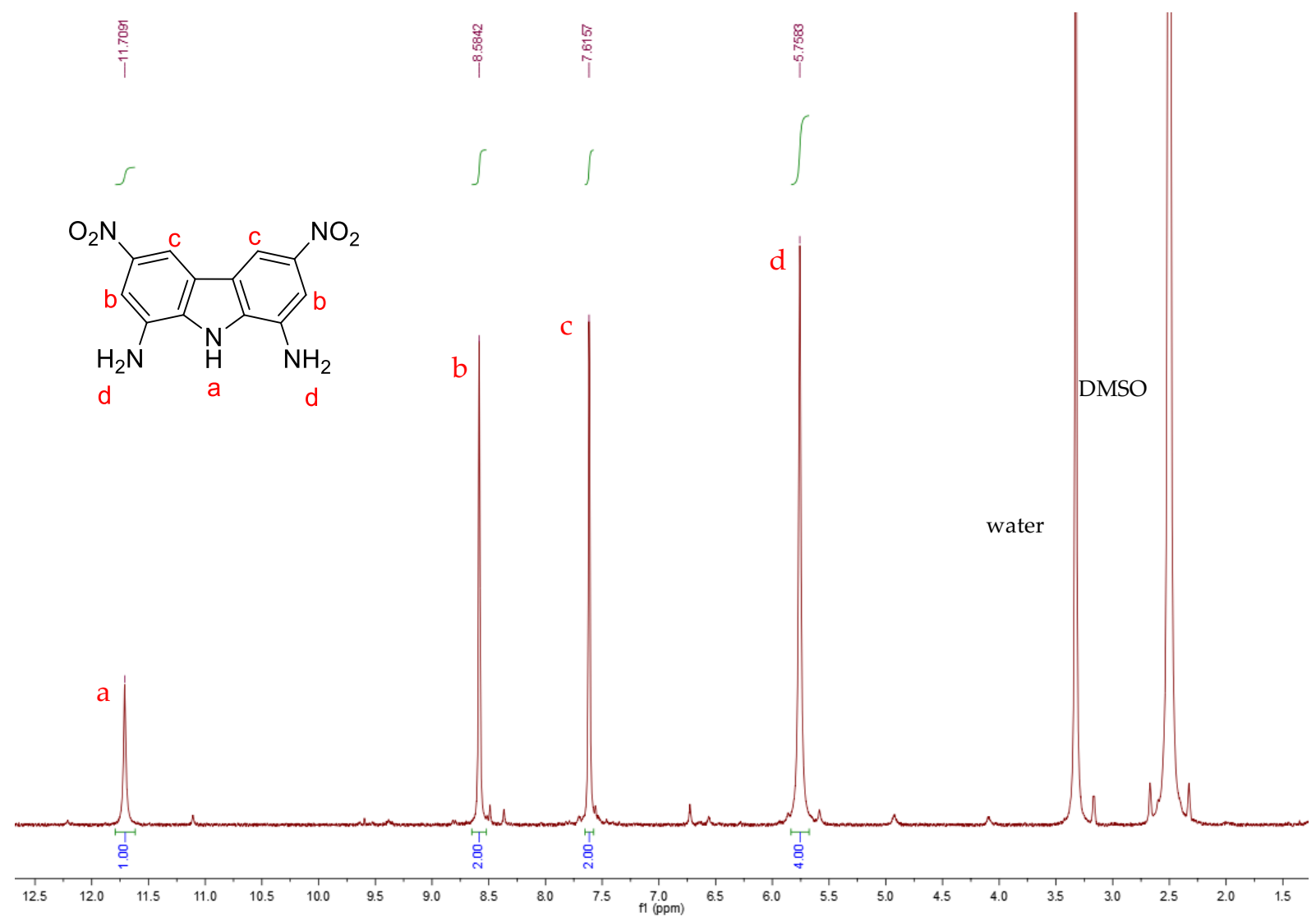

Figure S7. ${ }^{1} \mathrm{H}$ NMR spectrum of 1,8 -diamino-3,6-dinitrocarbazole in DMSO- $d_{6}$.
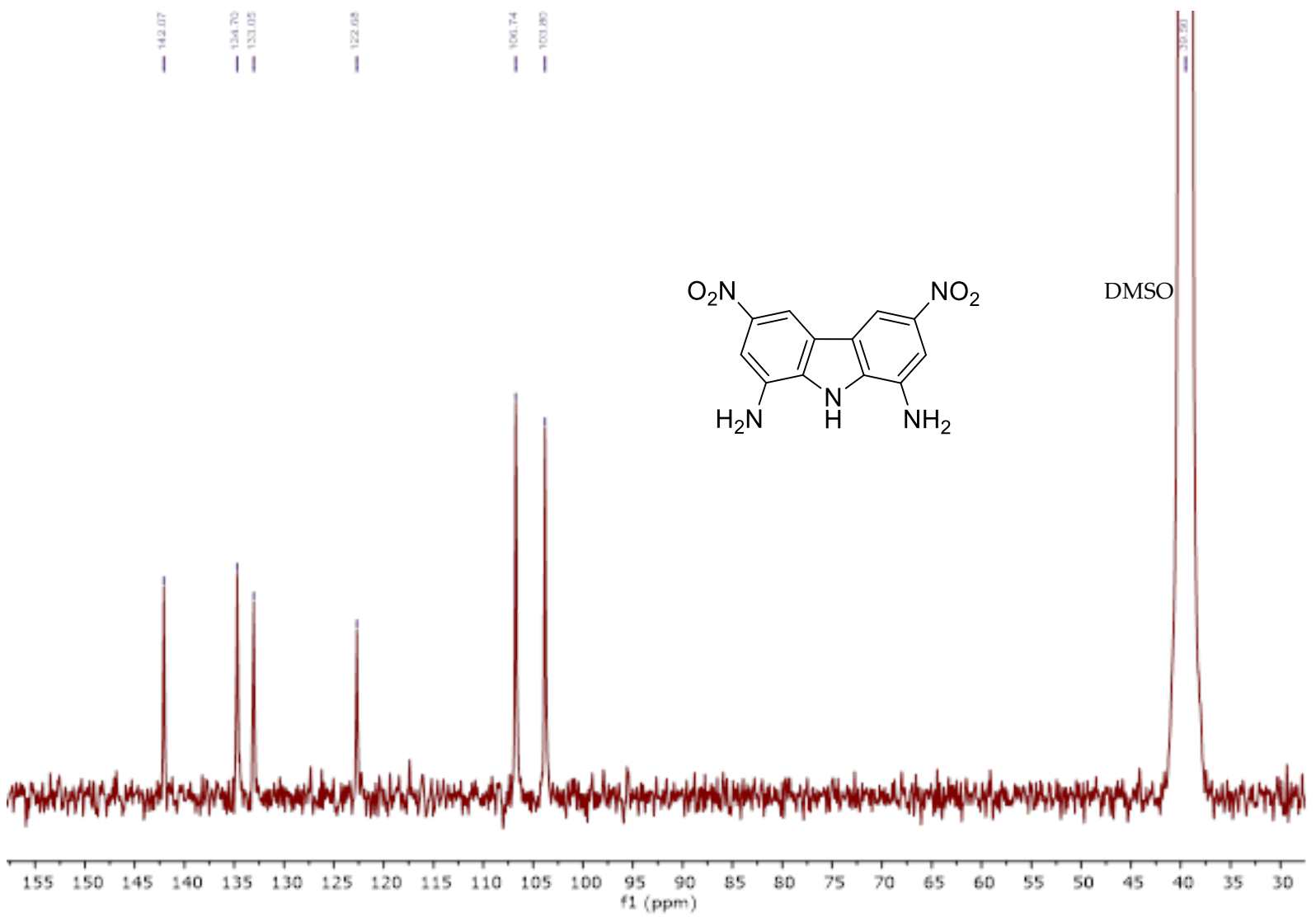

Figure S8. ${ }^{13} \mathrm{C}$ NMR spectrum of 1,8-diamino-3,6-dinitrocarbazole in DMSO- $d_{6}$. 


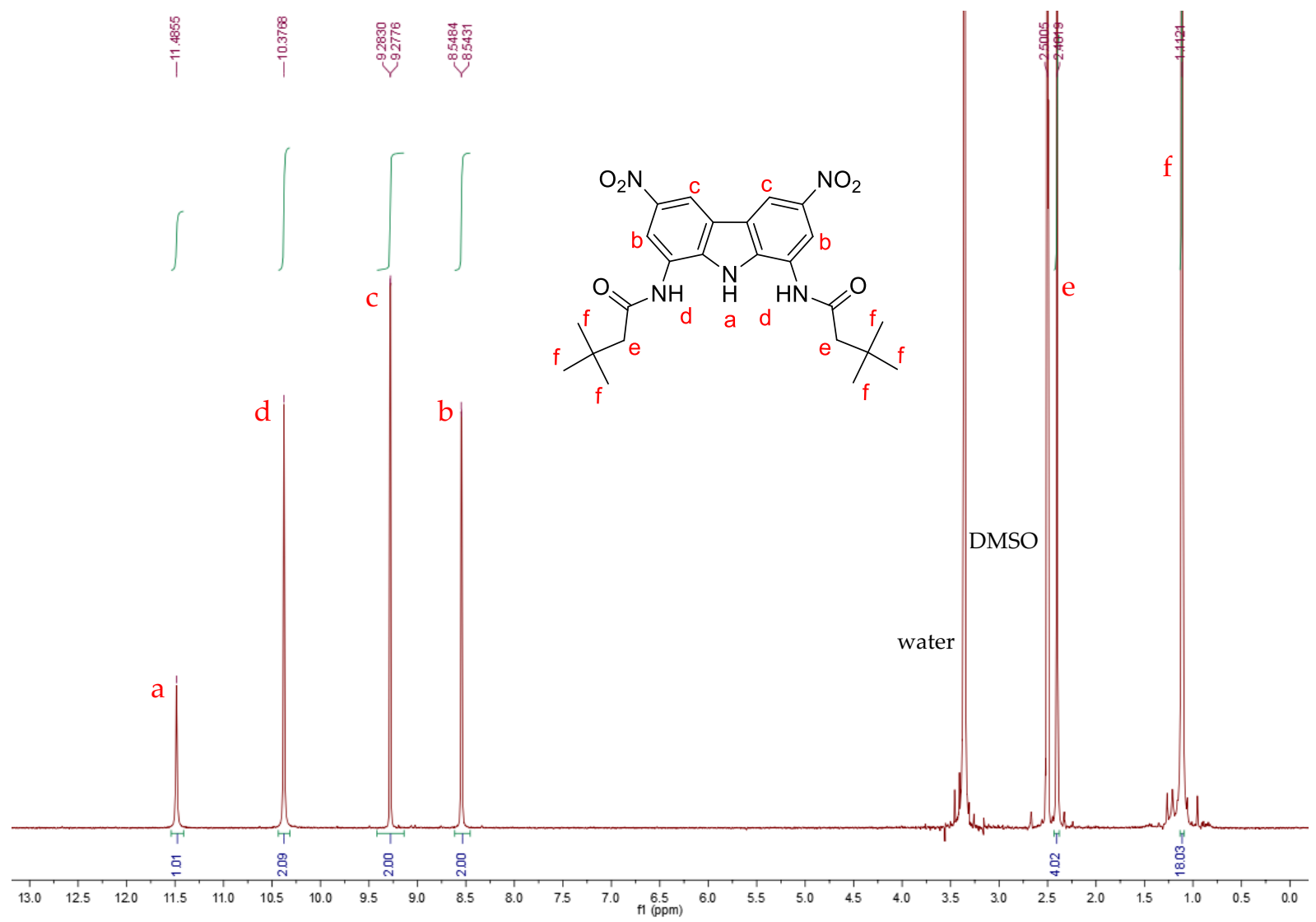

Figure S9. ${ }^{1} \mathrm{H}$ NMR spectrum of 4 in DMSO- $d_{6}$.

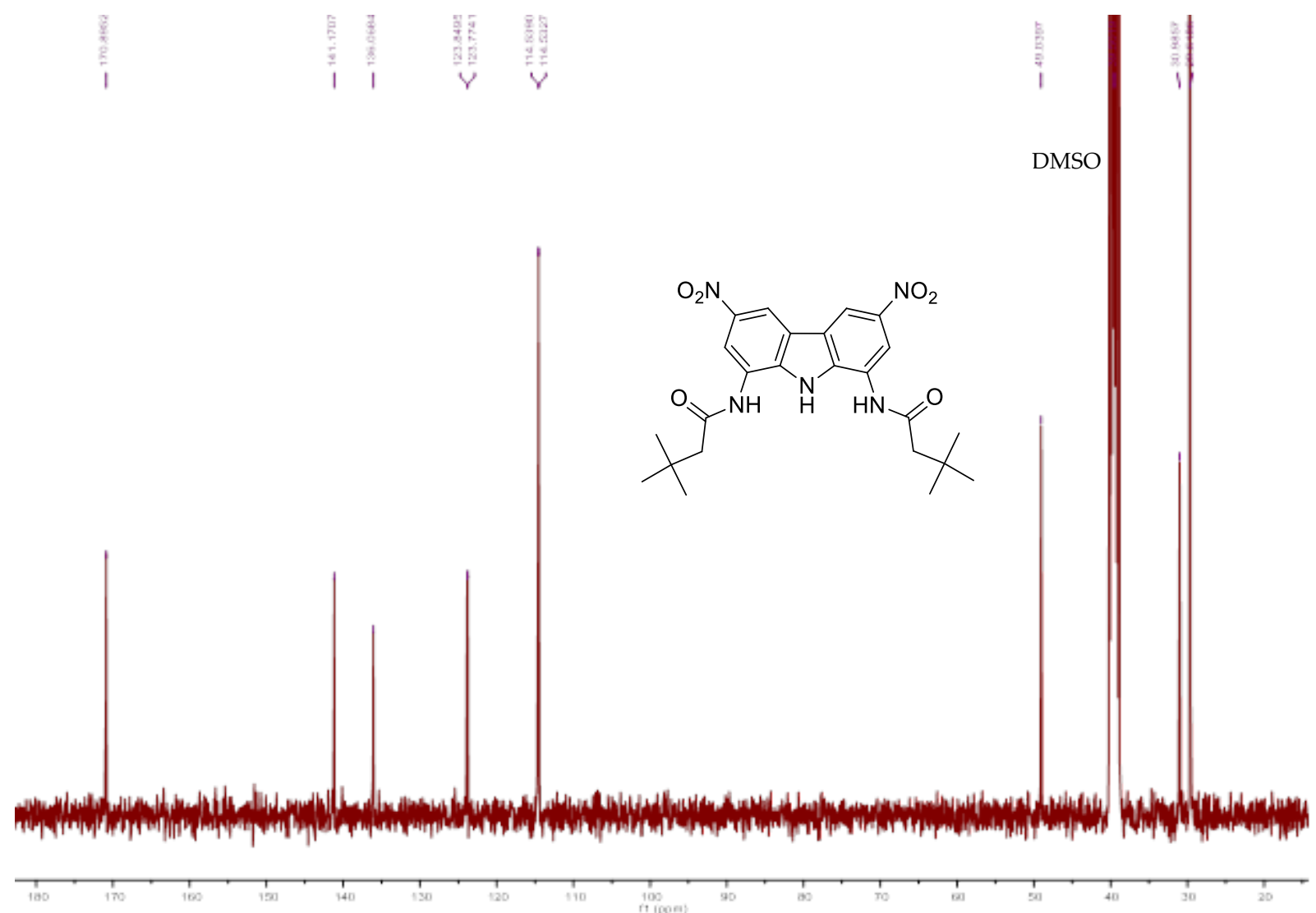

Figure S10. ${ }^{13} \mathrm{C}$ NMR spectrum of $\mathbf{4}$ in DMSO- $d_{6}$. 


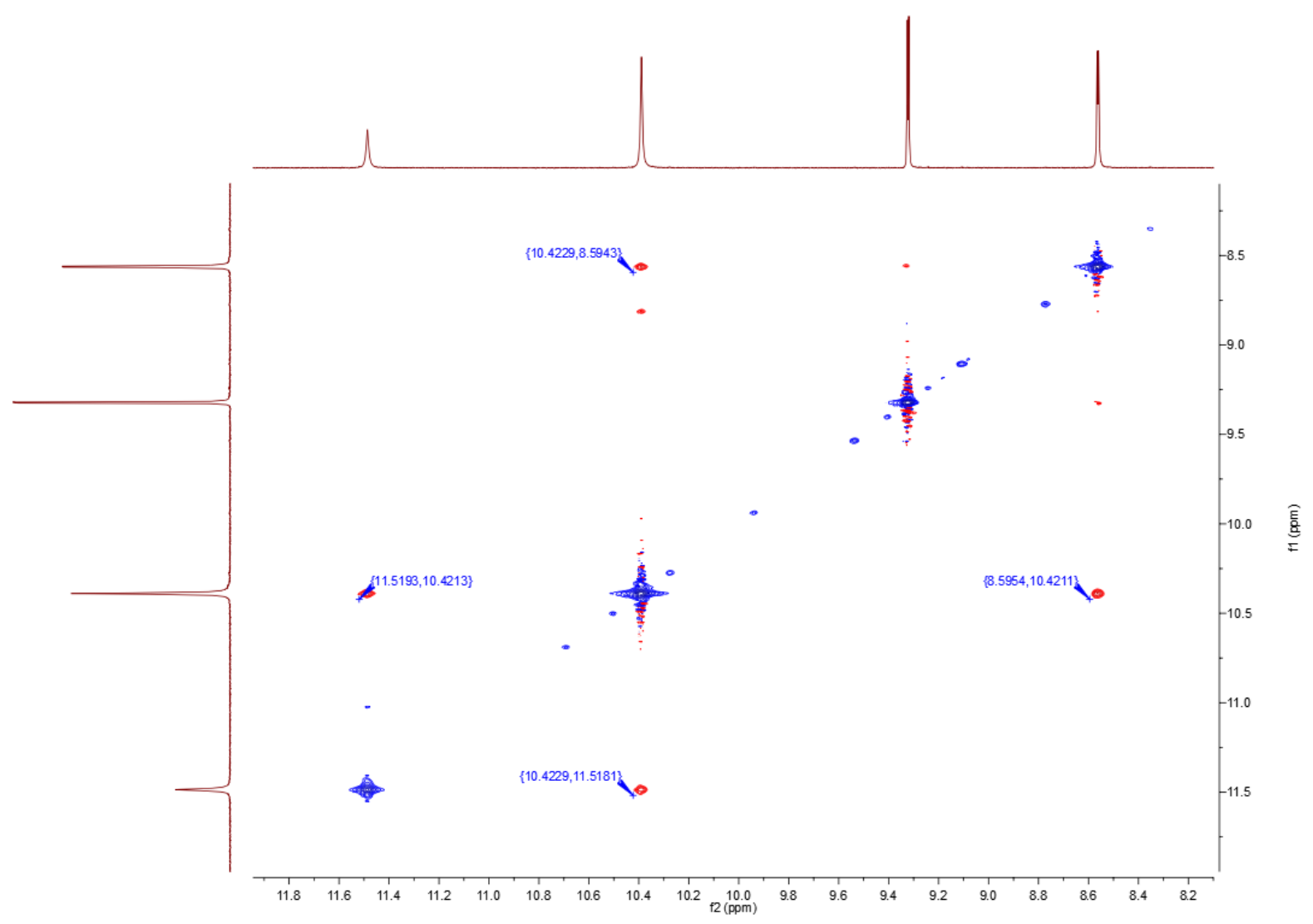

Figure S11. ${ }^{1} \mathrm{H}$ ROESY spectrum of 4 in DMSO- $d_{6}$.

2D ROESY (Rotation Frame Nuclear Overhauser Effect Spectroscopy) spectrum reveals which hydrogen atoms of $\mathbf{4}$ are close to each other in space. The protons of the amide groups interact with both carbazole proton NH at $11.52 \mathrm{ppm}$ and $\mathrm{CH} 2 / 7$ protons at 8.60 $\mathrm{ppm}$, what means that both syn and anti-conformations of the amide groups are populated in DMSO solution, as shown on Scheme S1.
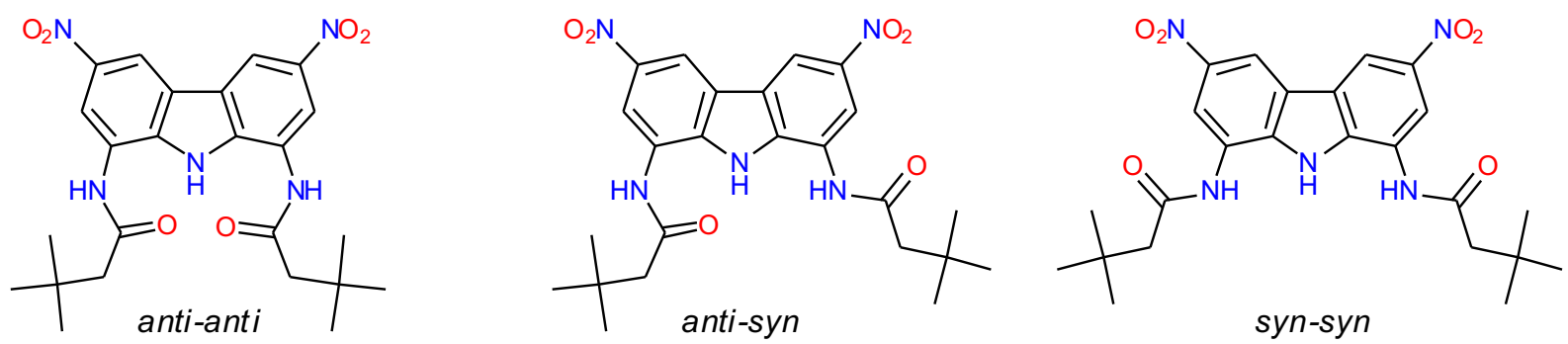

Scheme S1. Amide groups conformations in $\mathbf{4}$. 


\section{Binding studies}

2.1 Anion binding studies of receptor 3

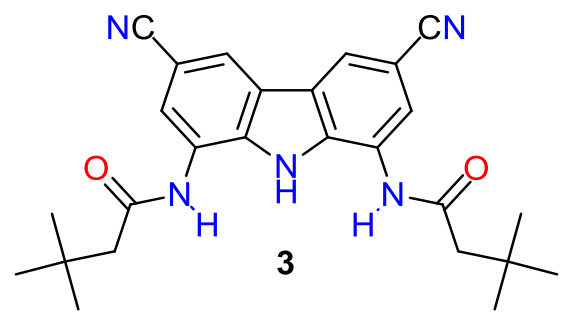

2.1.1 ${ }^{1} \mathrm{H}$ NMR titration of 3 with $\mathrm{Cl}^{-}$in $\mathrm{DMSO} / 0.5 \% \mathrm{H}_{2} \mathrm{O}$

${ }^{1} \mathrm{H}$ NMR titration of $0.01 \mathrm{M}$ solution of receptor 3 in $\mathrm{DMSO}_{-\mathrm{d}} / 0.5 \% \mathrm{H}_{2} \mathrm{O}$ with $0.3 \mathrm{M}$ solution of TBACl (dissolved in the solution of receptor 3).

a) ${ }^{1}$ H NMR spectra

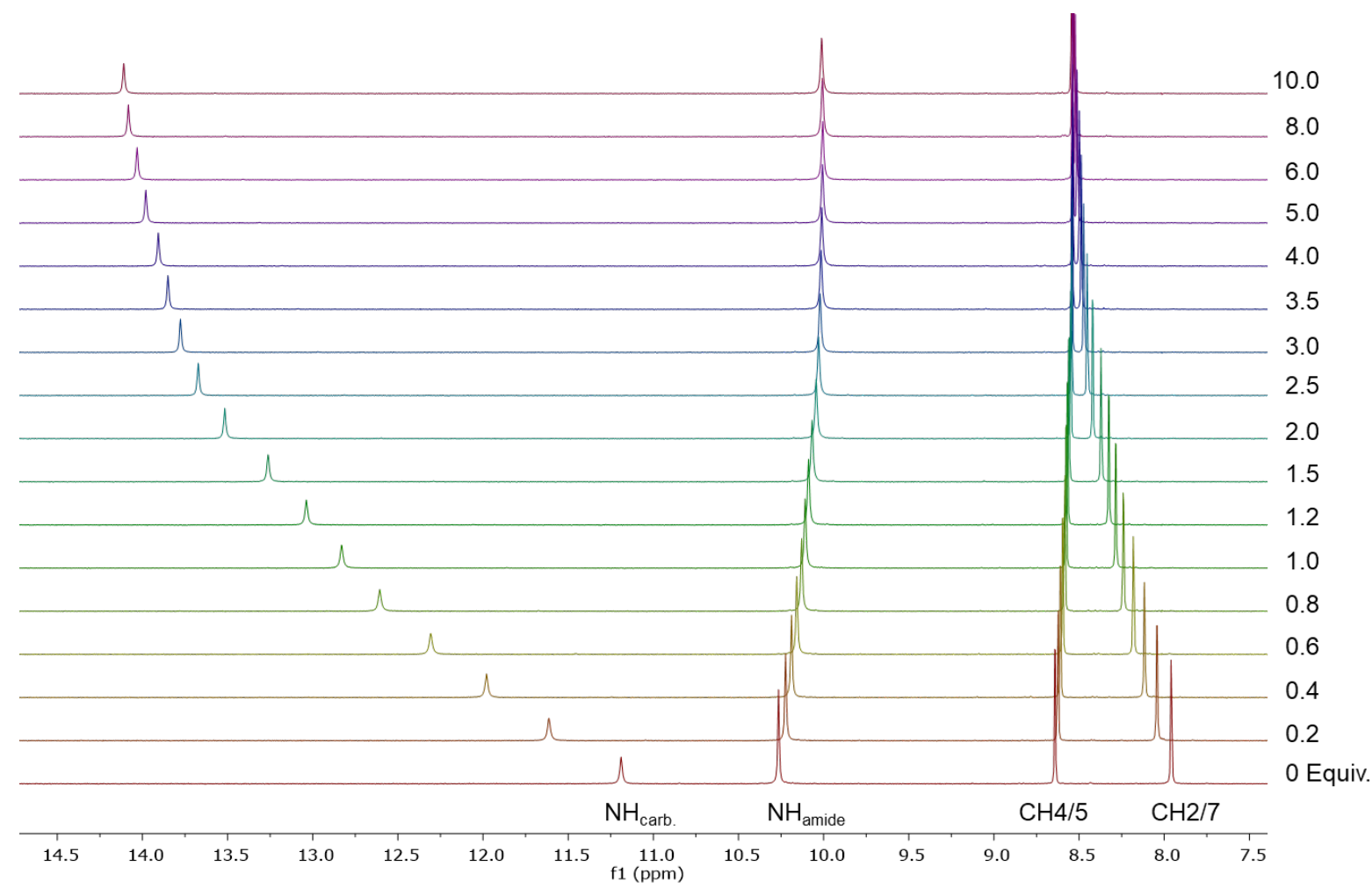


b) Raw data

\begin{tabular}{|c|c|c|c|}
\hline \multirow{2}{*}{$\begin{array}{c}\text { Added volume } \\
\text { of titrant }[\boldsymbol{\mu L}]\end{array}$} & \multirow{2}{*}{$\begin{array}{c}\text { Equivalents } \\
\text { of TBACl }\end{array}$} & \multicolumn{2}{|c|}{ Chemical shift [ppm] } \\
\cline { 3 - 4 } & 0 & $\mathbf{N H}_{\text {carb. }}$ & $\mathbf{N H}_{\text {amide }}$ \\
\hline 0.00 & 0.2 & 11.4867 & 10.3867 \\
\hline 4.00 & 0.4 & 11.7219 & 10.3584 \\
\hline 8.00 & 0.6 & 11.9426 & 10.3328 \\
\hline 16.25 & 0.8 & 12.3577 & 10.2793 \\
\hline 25.00 & 1.0 & 13.06951 & 10.2315 \\
\hline 33.75 & 1.2 & 13.3287 & 10.1919 \\
\hline 42.75 & 1.5 & 13.5376 & 10.1604 \\
\hline 52.25 & 2.0 & 13.7653 & 10.1350 \\
\hline 66.75 & 2.5 & 13.9954 & 10.074 \\
\hline 91.75 & 3.0 & 14.1334 & 10.0631 \\
\hline 120.00 & 3.5 & 14.2170 & 10.0537 \\
\hline 150.00 & 4.0 & 14.2728 & 10.0477 \\
\hline 182.50 & 5.0 & 14.3128 & 10.0438 \\
\hline 218.25 & 6.0 & 14.3676 & 10.0416 \\
\hline 300.00 & 8.0 & 14.3982 & 10.0387 \\
\hline 400.00 & 9.0 & 14.4319 & 10.0397 \\
\hline 686.00 & 10.0 & 14.4402 & 10.0409 \\
\hline 911.00 & & & \\
\hline
\end{tabular}

c) Titration curves of $\mathrm{NH}_{\text {carb. }}$ and $\mathrm{NH}_{\text {amide }}$ protons
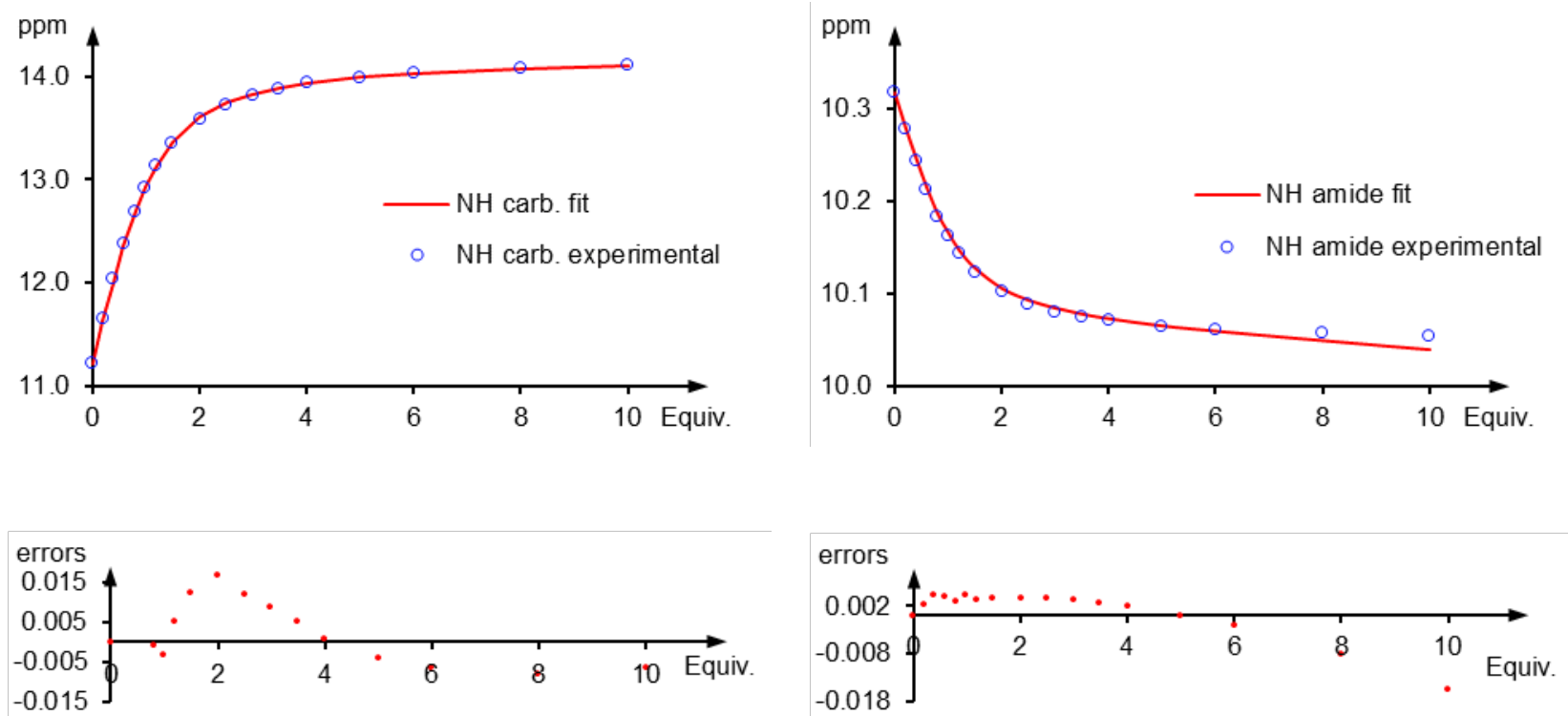

d) Logarithm of the binding constant log $\mathrm{K}$ derived from simultaneous fitting of 1:1 model to two selected protons using Bindfit:

$\log \mathrm{K}: \mathbf{2 . 4 9 7}$

e) Logarithm of binding constant log $\mathrm{K}$ derived from the experiment repeated according to the same methodology:

\section{$\log$ K: 2.491}

f) Logarithm of binding constant log $\mathrm{K}$ averaged from the two experiments: 


\subsubsection{UV-Vis titration of 3 with $\mathrm{H}_{2} \mathrm{PO}_{4}^{-}$in $\mathrm{DMSO} / 0.5 \% \mathrm{H}_{2} \mathrm{O}$}

UV-Vis titration of $1 \times 10^{-4} \mathrm{M}$ solution of receptor 3 in DMSO/0.5\% $\mathrm{H}_{2} \mathrm{O}$ with $0.0075 \mathrm{M}$ solution of $\mathrm{TBAH}_{2} \mathrm{PO}_{4}$ (dissolved in the solution of receptor $\mathbf{3}$ ).

a) UV-Vis spectra

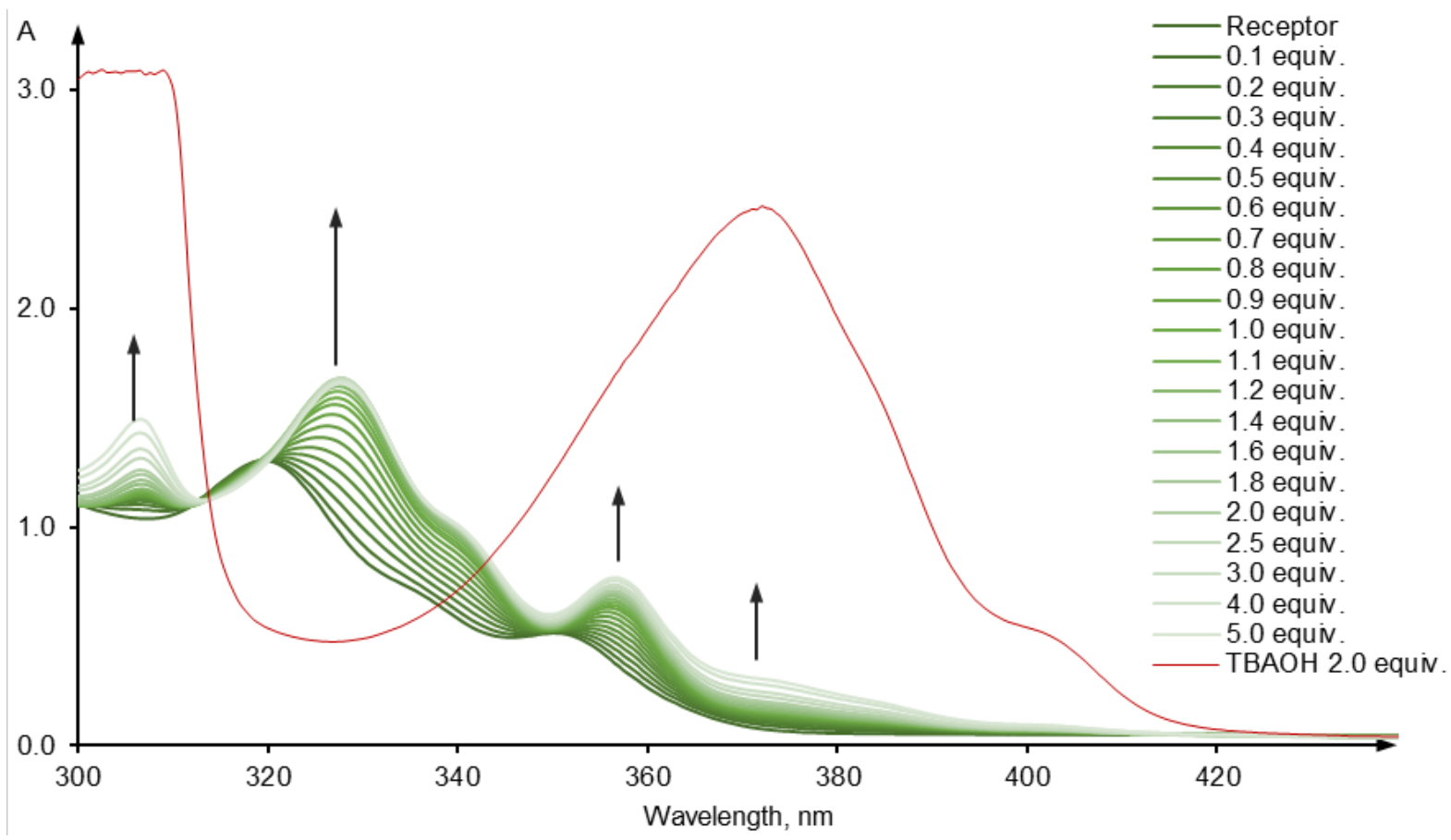

b) Raw data

\begin{tabular}{|c|c|c|c|c|c|}
\hline Equivalents of $\mathrm{TBAH}_{2} \mathbf{P O}_{\mathbf{4}}$ & $\mathbf{3 0 7} \mathbf{n m}$ & $\mathbf{3 2 8} \mathbf{n m}$ & $\mathbf{3 3 7 . 5} \mathbf{n m}$ & $\mathbf{3 5 7} \mathbf{n m}$ & $\mathbf{3 7 2} \mathbf{~ n m}$ \\
\hline 0.0 & 1.038 & 0.948 & 0.655 & 0.361 & 0.075 \\
\hline 0.1 & 1.080 & 1.015 & 0.693 & 0.398 & 0.098 \\
\hline 0.2 & 1.101 & 1.088 & 0.733 & 0.431 & 0.109 \\
\hline 0.3 & 1.117 & 1.163 & 0.772 & 0.460 & 0.117 \\
\hline 0.4 & 1.128 & 1.238 & 0.813 & 0.491 & 0.124 \\
\hline 0.5 & 1.137 & 1.309 & 0.852 & 0.520 & 0.131 \\
\hline 0.6 & 1.143 & 1.377 & 0.890 & 0.548 & 0.136 \\
\hline 0.7 & 1.147 & 1.446 & 0.926 & 0.576 & 0.141 \\
\hline 0.8 & 1.149 & 1.506 & 0.960 & 0.600 & 0.145 \\
\hline 0.9 & 1.155 & 1.554 & 0.988 & 0.621 & 0.150 \\
\hline 1.0 & 1.159 & 1.589 & 1.007 & 0.637 & 0.154 \\
\hline 1.1 & 1.166 & 1.617 & 1.025 & 0.651 & 0.159 \\
\hline 1.2 & 1.175 & 1.642 & 1.040 & 0.664 & 0.165 \\
\hline 1.4 & 1.195 & 1.663 & 1.054 & 0.679 & 0.175 \\
\hline 1.6 & 1.218 & 1.677 & 1.064 & 0.693 & 0.187 \\
\hline 1.8 & 1.242 & 1.682 & 1.070 & 0.702 & 0.197 \\
\hline 2.0 & 1.262 & 1.683 & 1.073 & 0.709 & 0.206 \\
\hline 2.5 & 1.314 & 1.681 & 1.077 & 0.724 & 0.229 \\
\hline 3.0 & 1.358 & 1.677 & 1.080 & 0.737 & 0.250 \\
\hline 4.0 & 1.430 & 1.670 & 1.082 & 0.754 & 0.279 \\
\hline 5.0 & 1.491 & 1.661 & 1.083 & 0.768 & 0.305 \\
\hline & & & & & \\
\hline
\end{tabular}


c) Titration curves at $337.5 \mathrm{~nm}$.

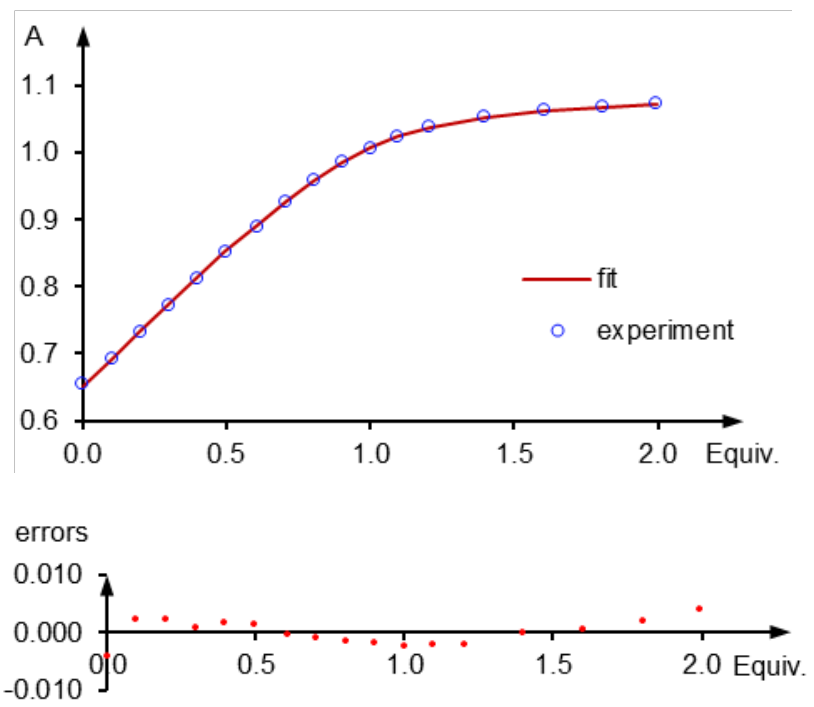

d) Logarithm of the binding constant log $\mathrm{K}$ derived from simultaneous fitting of 1:1 model to three selected wavelengths using HypSpec:

$\log$ K: 5.370 


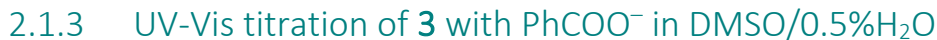

UV-Vis titration of $1 \times 10^{-4} \mathrm{M}$ solution of receptor 3 in DMSO/0.5\% $\mathrm{H}_{2} \mathrm{O}$ with $0.0075 \mathrm{M}$ solution of TBAPhCOO (dissolved in the solution of receptor $\mathbf{3}$ ).

a) UV-Vis spectra

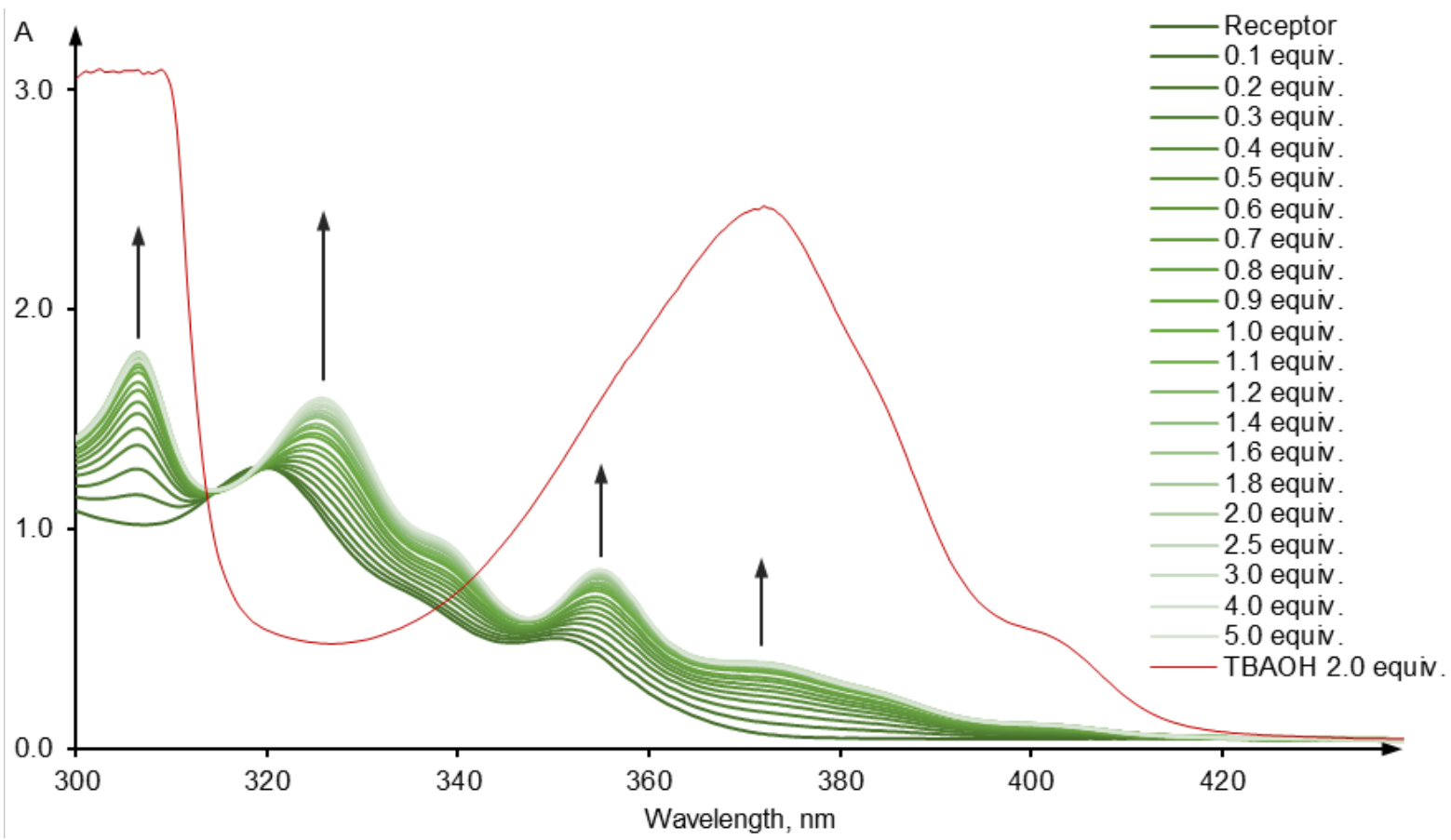

b) Raw data

\begin{tabular}{|c|c|c|c|c|}
\hline Equivalents of TBAPhCOO & $\mathbf{3 0 7} \mathbf{n m}$ & $\mathbf{3 2 6} \mathbf{n m}$ & $\mathbf{3 5 7} \mathbf{n m}$ & $\mathbf{3 7 2} \mathbf{~ m}$ \\
\hline 0.0 & 1.022 & 1.046 & 0.349 & 0.065 \\
\hline 0.1 & 1.154 & 1.074 & 0.393 & 0.119 \\
\hline 0.2 & 1.274 & 1.113 & 0.438 & 0.167 \\
\hline 0.3 & 1.376 & 1.158 & 0.480 & 0.207 \\
\hline 0.4 & 1.453 & 1.204 & 0.518 & 0.239 \\
\hline 0.5 & 1.520 & 1.248 & 0.552 & 0.265 \\
\hline 0.6 & 1.573 & 1.289 & 0.581 & 0.288 \\
\hline 0.7 & 1.627 & 1.331 & 0.611 & 0.310 \\
\hline 0.8 & 1.661 & 1.363 & 0.633 & 0.325 \\
\hline 0.9 & 1.706 & 1.404 & 0.662 & 0.349 \\
\hline 1.0 & 1.733 & 1.426 & 0.677 & 0.359 \\
\hline 1.1 & 1.743 & 1.450 & 0.689 & 0.365 \\
\hline 1.2 & 1.758 & 1.471 & 0.704 & 0.372 \\
\hline 1.4 & 1.772 & 1.502 & 0.718 & 0.379 \\
\hline 1.6 & 1.786 & 1.521 & 0.733 & 0.385 \\
\hline 1.8 & 1.795 & 1.534 & 0.741 & 0.390 \\
\hline 2.0 & 1.798 & 1.537 & 0.739 & 0.389 \\
\hline 2.5 & 1.798 & 1.558 & 0.752 & 0.391 \\
\hline 3.0 & 1.791 & 1.570 & 0.756 & 0.388 \\
\hline 4.0 & 1.782 & 1.586 & 0.759 & 0.386 \\
\hline 5.0 & 1.763 & 1.599 & 0.760 & 0.379 \\
\hline & & & & \\
\hline
\end{tabular}




\subsubsection{UV-Vis titration of 3 with $\mathrm{OH}^{-}$in $\mathrm{DMSO} / 0.5 \% \mathrm{H}_{2} \mathrm{O}$}

UV-Vis titration of $1 \times 10^{-4} \mathrm{M}$ solution of receptor 3 in DMSO/0.5\% $\mathrm{H}_{2} \mathrm{O}$ with $0.0075 \mathrm{M}$ solution of TBAOH (dissolved in the solution of receptor 3).

a) UV-Vis spectra

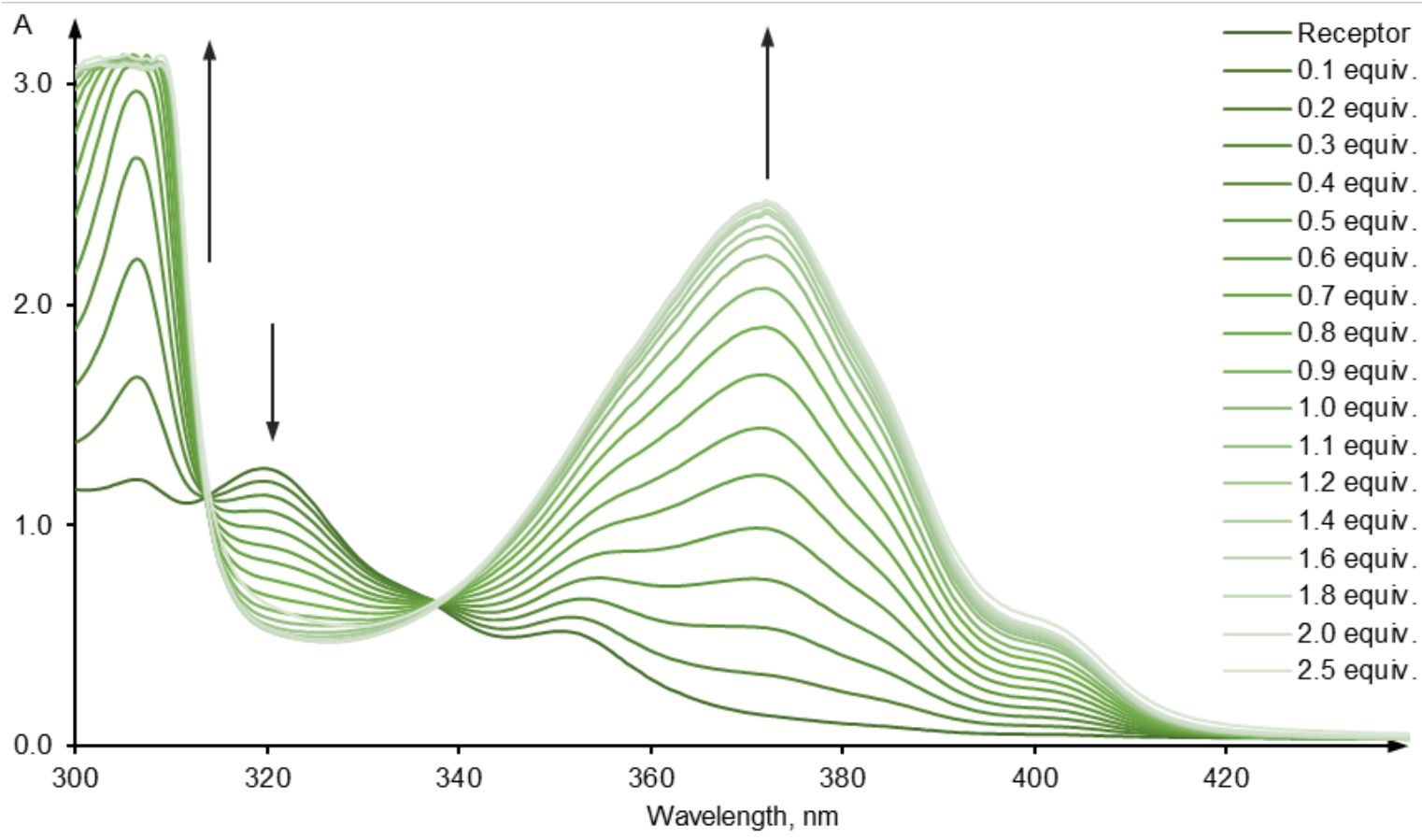

b) Raw data

\begin{tabular}{|c|c|c|c|c|}
\hline Equivalents of TBAOH & $\mathbf{3 0 7} \mathbf{n m}$ & $\mathbf{3 2 0} \mathbf{n m}$ & $\mathbf{3 5 0} \mathbf{n m}$ & $\mathbf{3 7 2} \mathbf{~ n}$ \\
\hline 0.0 & 1.202 & 1.254 & 0.520 & 0.141 \\
\hline 0.1 & 1.667 & 1.201 & 0.575 & 0.321 \\
\hline 0.2 & 2.188 & 1.133 & 0.639 & 0.533 \\
\hline 0.3 & 2.648 & 1.063 & 0.706 & 0.753 \\
\hline 0.4 & 2.955 & 0.986 & 0.777 & 0.987 \\
\hline 0.5 & 3.081 & 0.906 & 0.850 & 1.227 \\
\hline 0.6 & 3.102 & 0.838 & 0.915 & 1.439 \\
\hline 0.7 & 3.105 & 0.758 & 0.989 & 1.682 \\
\hline 0.8 & 3.096 & 0.685 & 1.058 & 1.900 \\
\hline 0.9 & 3.094 & 0.625 & 1.115 & 2.078 \\
\hline 1.0 & 3.082 & 0.579 & 1.161 & 2.220 \\
\hline 1.1 & 3.102 & 0.549 & 1.192 & 2.307 \\
\hline 1.2 & 3.076 & 0.534 & 1.209 & 2.360 \\
\hline 1.4 & 3.080 & 0.526 & 1.224 & 2.414 \\
\hline 1.6 & 3.073 & 0.527 & 1.231 & 2.433 \\
\hline 1.8 & 3.065 & 0.532 & 1.242 & 2.454 \\
\hline 2.0 & 3.074 & 0.535 & 1.248 & 2.471 \\
\hline 2.5 & 3.110 & 0.646 & 1.247 & 2.469 \\
\hline & & & & \\
\hline
\end{tabular}


2.2 Anion binding studies of receptor 4

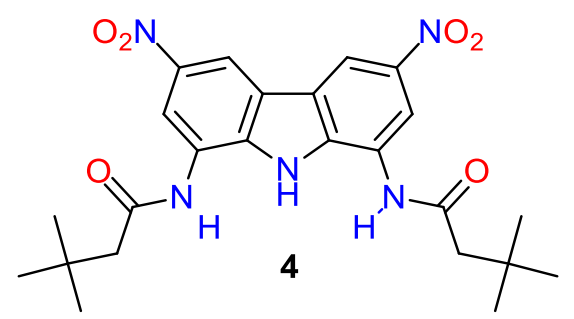

2.2.1 ${ }^{1} \mathrm{H}$ NMR titration of 4 with $\mathrm{Cl}^{-}$in $\mathrm{DMSO} / 0.5 \% \mathrm{H}_{2} \mathrm{O}$

${ }^{1} \mathrm{H}$ NMR titration of $0.01 \mathrm{M}$ solution of receptor 4 in DMSO-d6 $/ 0.5 \% \mathrm{H}_{2} \mathrm{O}$ with $0.3 \mathrm{M}$ solution of TBACl (dissolved in the solution of receptor 4).

a) ${ }^{1} \mathrm{H}$ NMR spectra

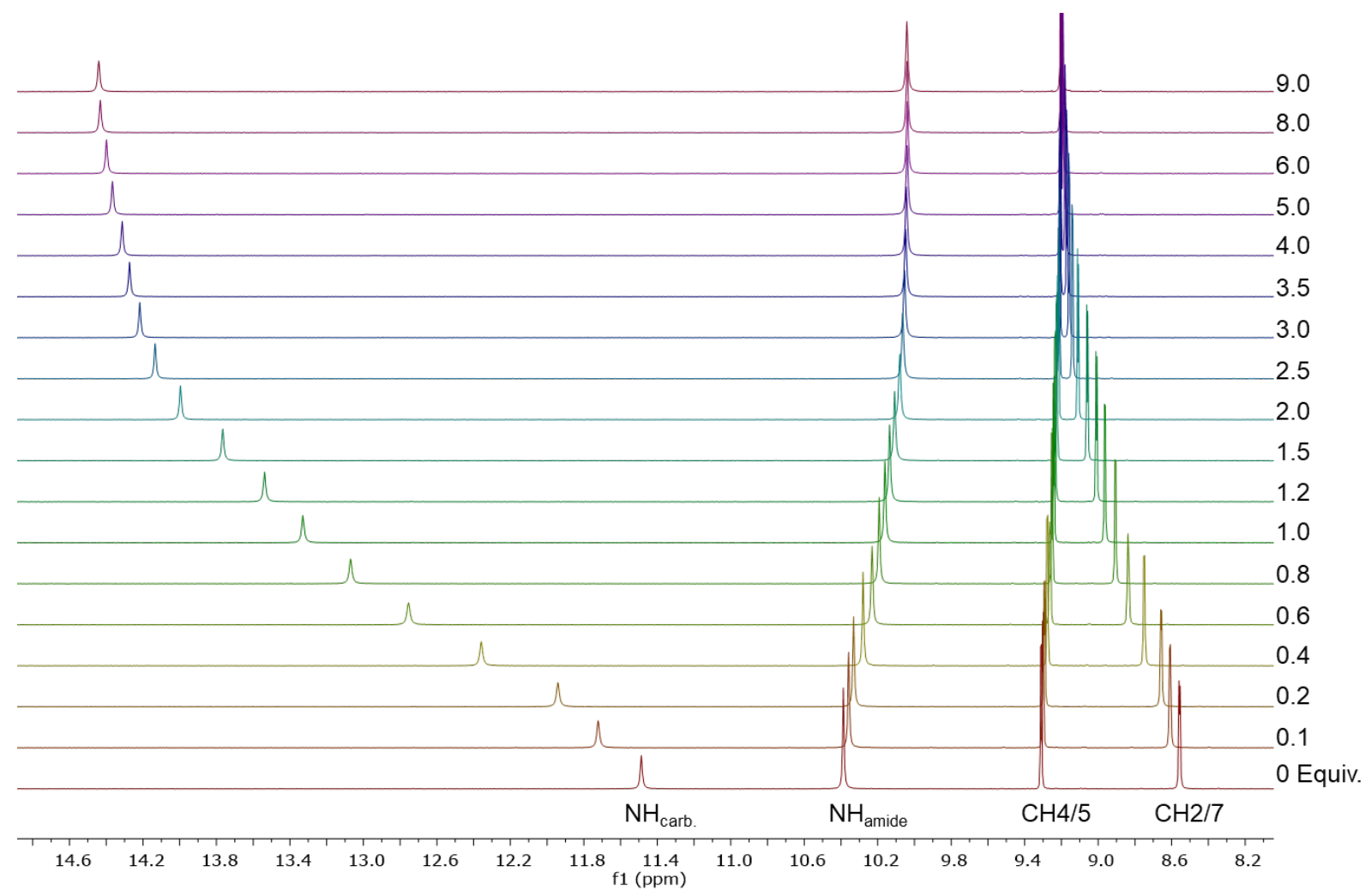


b) Raw data

\begin{tabular}{|c|c|c|c|}
\hline \multirow{2}{*}{$\begin{array}{c}\text { Added volume } \\
\text { of titrant }[\boldsymbol{\mu L} \text { ] }\end{array}$} & \multirow{2}{*}{$\begin{array}{c}\text { Equivalents } \\
\text { of TBACl }\end{array}$} & \multicolumn{2}{|c|}{ Chemical shift [ppm] } \\
\cline { 3 - 4 } & $\mathbf{\mathbf { N H } _ { \text { carb. } }}$ & $\mathbf{N H}_{\text {amide }}$ \\
\hline 0.00 & 0 & 11.4867 & 10.3867 \\
\hline 4.00 & 0.1 & 11.7219 & 10.3584 \\
\hline 8.00 & 0.2 & 11.9426 & 10.3328 \\
\hline 16.25 & 0.4 & 12.3577 & 10.2793 \\
\hline 25.00 & 0.6 & 12.7551 & 10.2315 \\
\hline 33.75 & 0.8 & 13.0694 & 10.1919 \\
\hline 42.75 & 1.0 & 13.3287 & 10.1604 \\
\hline 52.25 & 1.2 & 13.5376 & 10.1350 \\
\hline 66.75 & 1.5 & 13.7653 & 10.1074 \\
\hline 91.75 & 2.0 & 13.9954 & 10.0795 \\
\hline 120.00 & 2.5 & 14.1334 & 10.0631 \\
\hline 150.00 & 3.0 & 14.2170 & 10.0537 \\
\hline 182.50 & 3.5 & 14.2728 & 10.0477 \\
\hline 218.25 & 4.0 & 14.3128 & 10.0438 \\
\hline 300.00 & 5.0 & 14.3676 & 10.0416 \\
\hline 400.00 & 6.0 & 14.3982 & 10.0387 \\
\hline 686.00 & 8.0 & 14.4319 & 10.0397 \\
\hline 911.00 & 9.0 & 14.4402 & 10.0409 \\
\hline & & &
\end{tabular}

c) Titration curve of $\mathrm{NH}_{\text {carb. }}$ and $\mathrm{NH}_{\text {amide }}$ protons
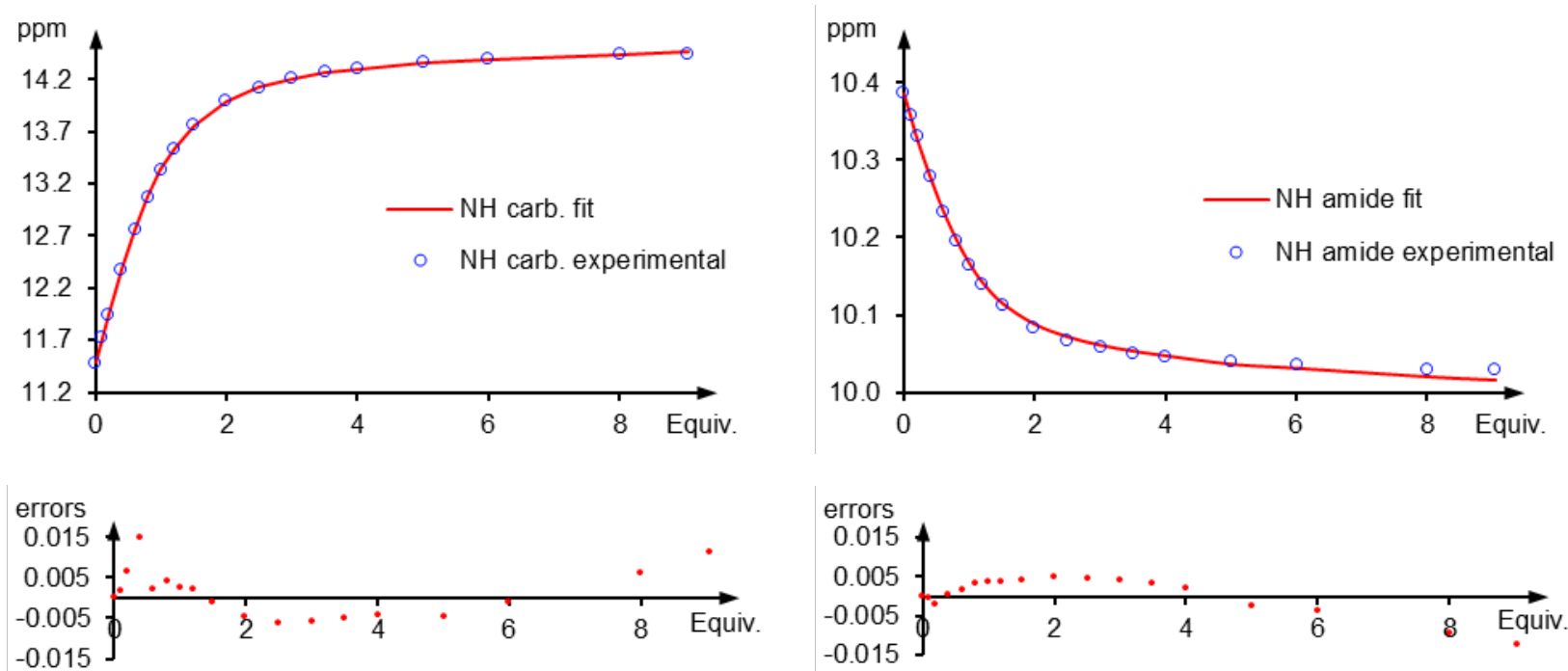

d) Logarithm of the binding constant log $\mathrm{K}$ derived from simultaneous fitting of 1:1 model to two selected protons using Bindfit:

$\log$ K: 2.584

e) Logarithm of the binding constant log $\mathrm{K}$ derived from the experiment repeated according to the same methodology:

$\log \mathrm{K}: \mathbf{2 . 4 9 1}$

f) Logarithm of the binding constant log $\mathrm{K}$ averaged from the two experiments: 


\subsubsection{UV-Vis titration of 4 with $\mathrm{H}_{2} \mathrm{PO}_{4}^{-}$in $\mathrm{DMSO} / 0.5 \% \mathrm{H}_{2} \mathrm{O}$}

UV-Vis titration of $1 \times 10^{-4} \mathrm{M}$ solution of receptor 4 in DMSO/0.5\% $\mathrm{H}_{2} \mathrm{O}$ with $0.0075 \mathrm{M}$ solution of $\mathrm{TBAH}_{2} \mathrm{PO}_{4}$ (dissolved in the solution of receptor 4).

a) UV-Vis spectra

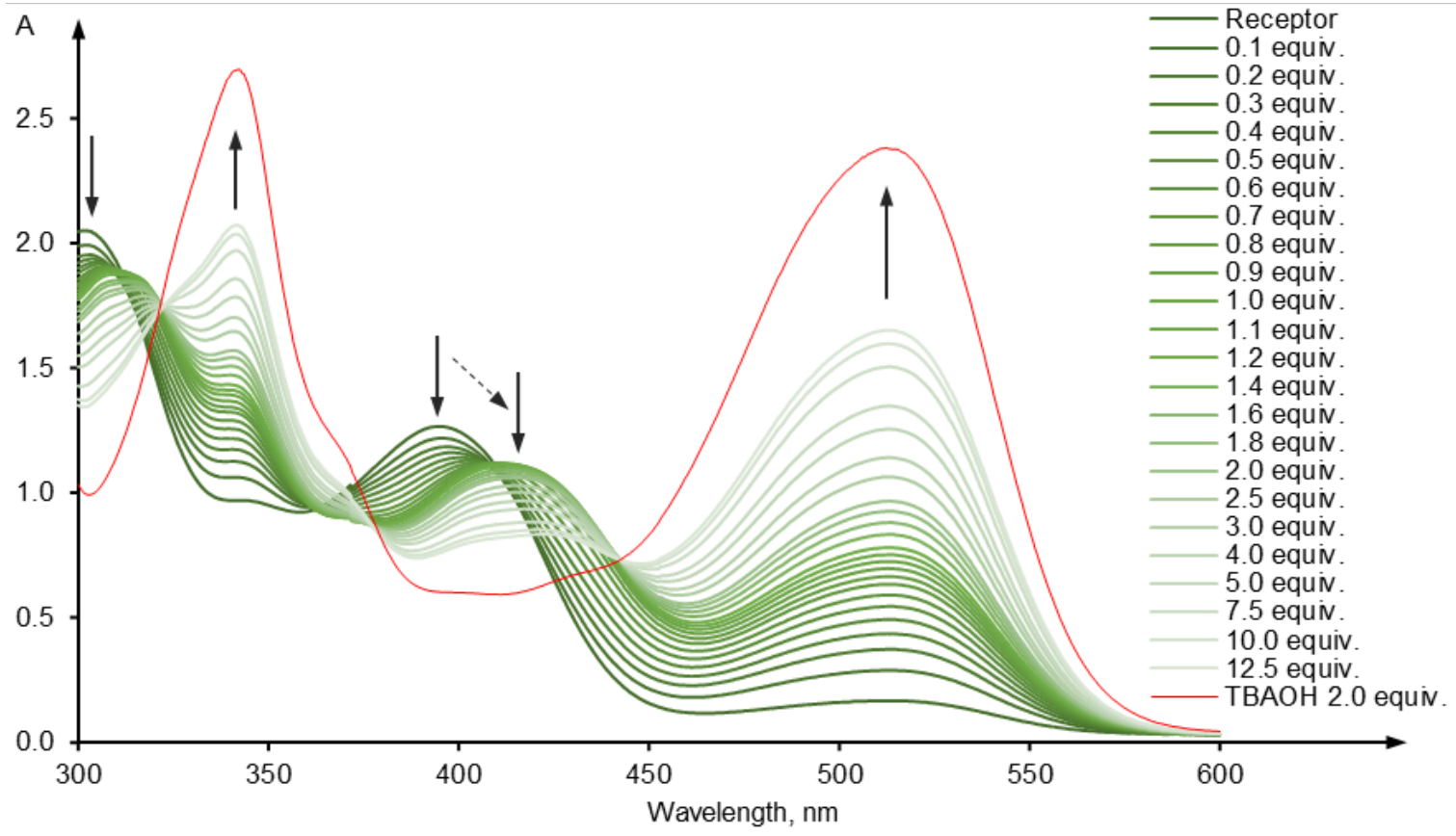

b) Raw data

\begin{tabular}{|c|c|c|c|c|}
\hline Equivalents of $\mathrm{TBAH}_{2} \mathrm{PO}_{4}$ & $343 \mathrm{~nm}$ & $392 \mathrm{~nm}$ & $465 \mathrm{~nm}$ & $513 \mathrm{~nm}$ \\
\hline 0.0 & 0.970 & 1.261 & 0.117 & 0.167 \\
\hline 0.1 & 1.061 & 1.211 & 0.183 & 0.289 \\
\hline 0.2 & 1.123 & 1.171 & 0.231 & 0.373 \\
\hline 0.3 & 1.170 & 1.140 & 0.269 & 0.435 \\
\hline 0.4 & 1.212 & 1.108 & 0.305 & 0.493 \\
\hline 0.5 & 1.249 & 1.078 & 0.338 & 0.545 \\
\hline 0.6 & 1.282 & 1.050 & 0.368 & 0.591 \\
\hline 0.7 & 1.312 & 1.022 & 0.397 & 0.634 \\
\hline 0.8 & 1.331 & 1.003 & 0.418 & 0.665 \\
\hline 0.9 & 1.354 & 0.986 & 0.438 & 0.697 \\
\hline 1.0 & 1.379 & 0.972 & 0.455 & 0.725 \\
\hline 1.1 & 1.398 & 0.961 & 0.470 & 0.752 \\
\hline 1.2 & 1.420 & 0.952 & 0.484 & 0.781 \\
\hline 1.4 & 1.458 & 0.937 & 0.509 & 0.833 \\
\hline 1.6 & 1.495 & 0.925 & 0.532 & 0.881 \\
\hline 1.8 & 1.530 & 0.914 & 0.553 & 0.926 \\
\hline 2.0 & 1.559 & 0.905 & 0.572 & 0.967 \\
\hline 2.5 & 1.635 & 0.882 & 0.616 & 1.064 \\
\hline 3.0 & 1.693 & 0.863 & 0.651 & 1.141 \\
\hline 4.0 & 1.775 & 0.838 & 0.702 & 1.255 \\
\hline 5.0 & 1.848 & 0.817 & 0.745 & 1.348 \\
\hline 7.5 & 1.960 & 0.781 & 0.817 & 1.505 \\
\hline 10.0 & 2.025 & 0.759 & 0.861 & 1.598 \\
\hline 12.5 & 2.064 & 0.746 & 0.888 & 1.652 \\
\hline
\end{tabular}




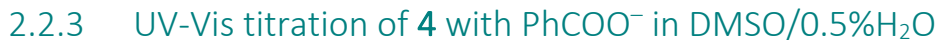

UV-Vis titration of $1 \times 10^{-4} \mathrm{M}$ solution of receptor 4 in DMSO/0.5\% $\mathrm{H}_{2} \mathrm{O}$ with $0.0075 \mathrm{M}$ solution of TBAPhCOO (dissolved in the solution of receptor 4).

a) UV-Vis spectra

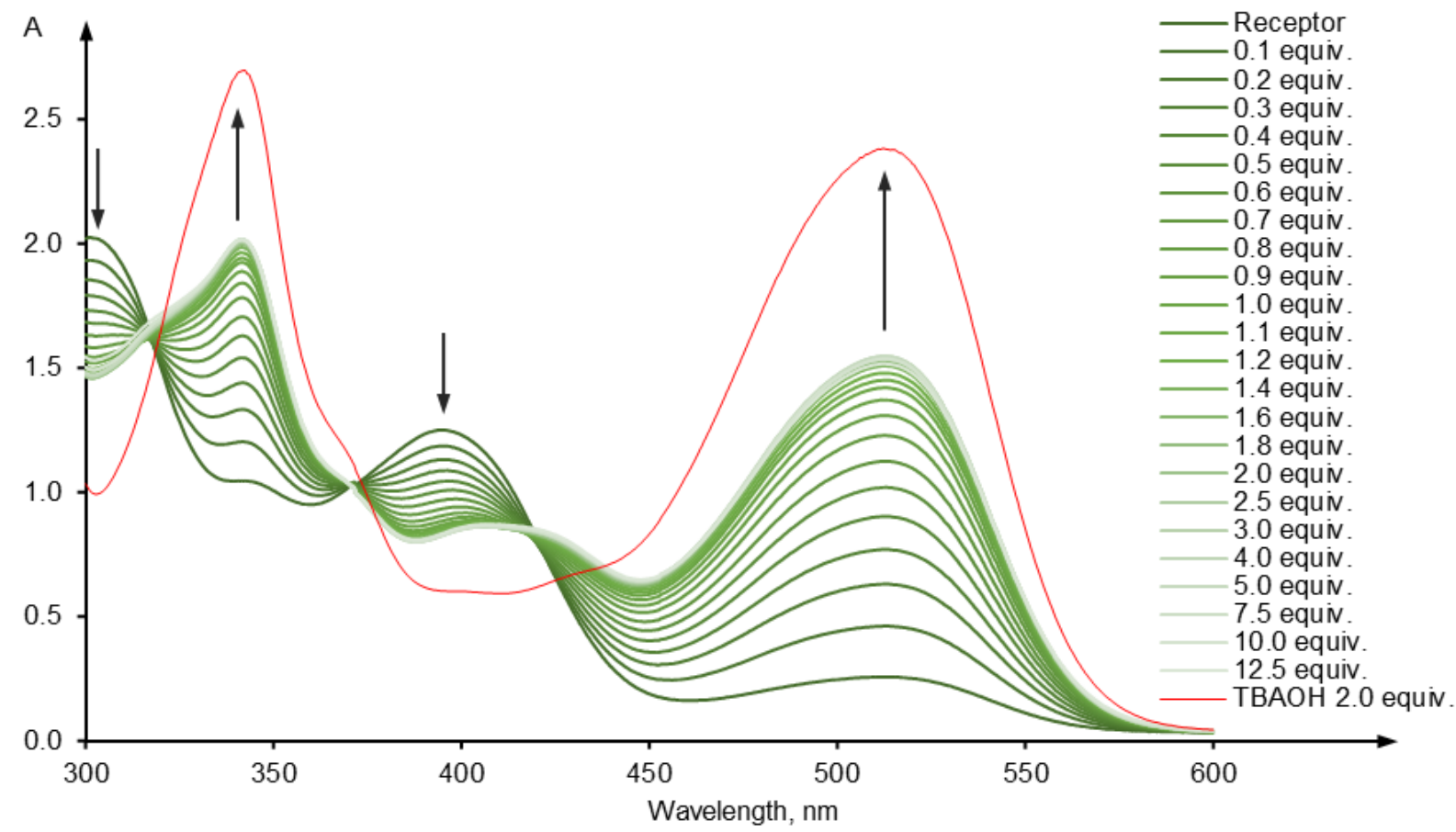

b) Raw data

\begin{tabular}{|c|c|c|c|c|}
\hline Equivalents of TBAPhCOO & $345 \mathrm{~nm}$ & $397 \mathrm{~nm}$ & $450 \mathrm{~nm}$ & $515 \mathrm{~nm}$ \\
\hline 0.0 & 1.040 & 1.246 & 0.189 & 0.257 \\
\hline 0.1 & 1.189 & 1.184 & 0.254 & 0.460 \\
\hline 0.2 & 1.311 & 1.130 & 0.309 & 0.628 \\
\hline 0.3 & 1.412 & 1.086 & 0.356 & 0.767 \\
\hline 0.4 & 1.509 & 1.044 & 0.402 & 0.900 \\
\hline 0.5 & 1.592 & 1.008 & 0.443 & 1.016 \\
\hline 0.6 & 1.665 & 0.972 & 0.480 & 1.122 \\
\hline 0.7 & 1.737 & 0.939 & 0.518 & 1.225 \\
\hline 0.8 & 1.794 & 0.912 & 0.547 & 1.305 \\
\hline 0.9 & 1.837 & 0.892 & 0.571 & 1.367 \\
\hline 1.0 & 1.871 & 0.877 & 0.589 & 1.416 \\
\hline 1.1 & 1.889 & 0.868 & 0.601 & 1.447 \\
\hline 1.2 & 1.910 & 0.858 & 0.613 & 1.475 \\
\hline 1.4 & 1.930 & 0.849 & 0.624 & 1.504 \\
\hline 1.6 & 1.942 & 0.844 & 0.631 & 1.520 \\
\hline 1.8 & 1.947 & 0.841 & 0.635 & 1.528 \\
\hline 2.0 & 1.947 & 0.841 & 0.635 & 1.528 \\
\hline 2.5 & 1.952 & 0.842 & 0.639 & 1.535 \\
\hline 3.0 & 1.957 & 0.839 & 0.642 & 1.540 \\
\hline 4.0 & 1.960 & 0.837 & 0.644 & 1.543 \\
\hline 5.0 & 1.961 & 0.837 & 0.646 & 1.543 \\
\hline 7.5 & 1.961 & 0.839 & 0.648 & 1.532 \\
\hline 10.0 & 1.961 & 0.839 & 0.648 & 1.532 \\
\hline 12.5 & 1.960 & 0.846 & 0.652 & 1.512 \\
\hline
\end{tabular}




\subsubsection{UV-Vis titration of 4 with $\mathrm{Cl}^{-}$in $\mathrm{DMSO} / 0.5 \% \mathrm{H}_{2} \mathrm{O}$}

UV-Vis titration of $2 \times 10^{-4} \mathrm{M}$ solution of receptor 4 in DMSO/0.5\% $\mathrm{H}_{2} \mathrm{O}$ with $0.090 \mathrm{M}$ solution of TBACl (dissolved in the solution of receptor 4).

a) UV-Vis spectra

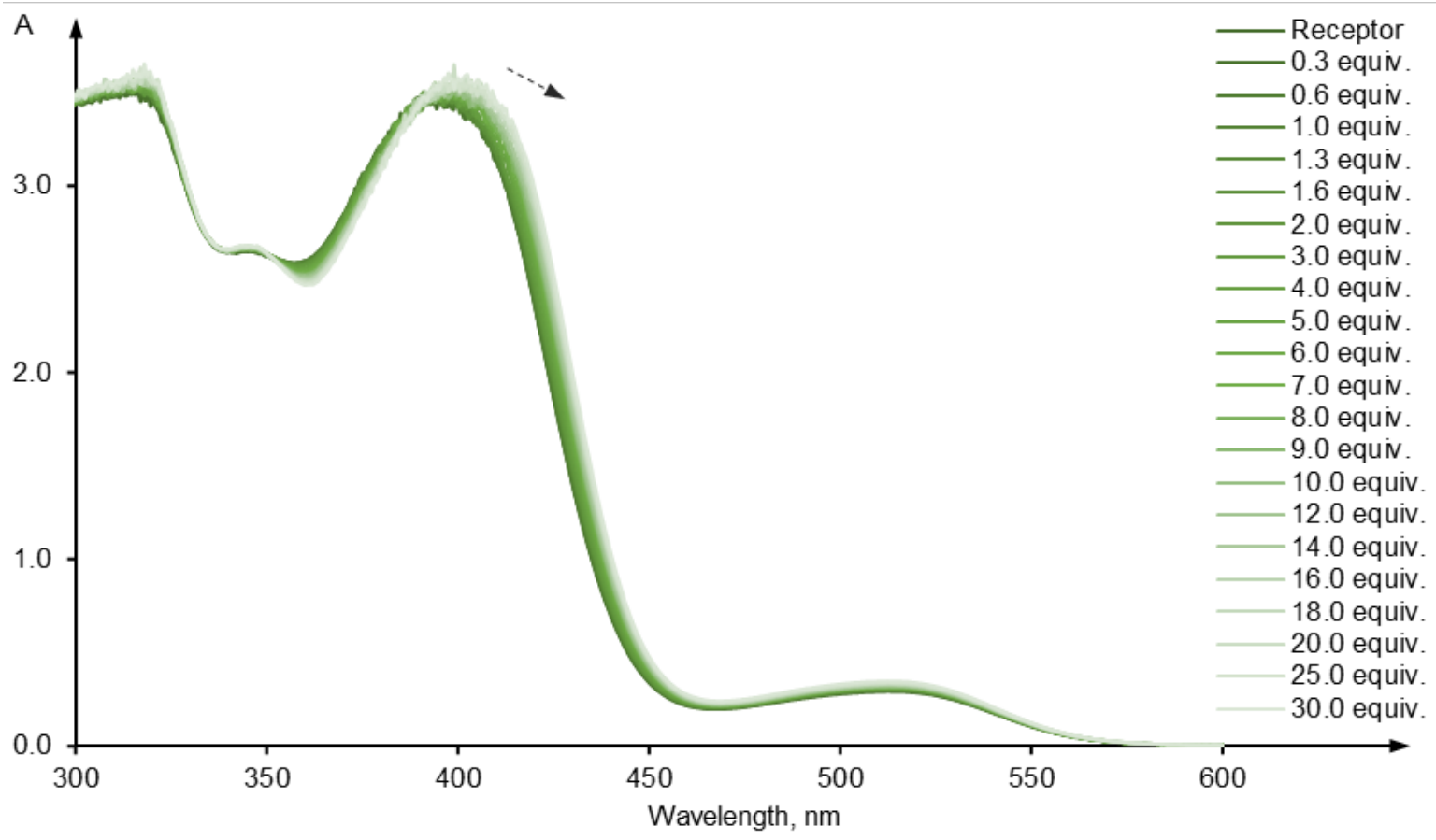

b) Raw data

\begin{tabular}{|c|c|c|c|}
\hline Equivalents of TBACl & $361 \mathrm{~nm}$ & $430 \mathrm{~nm}$ & $515 \mathrm{~nm}$ \\
\hline 0.0 & 2.603 & 1.393 & 0.291 \\
\hline 0.3 & 2.608 & 1.403 & 0.297 \\
\hline 0.6 & 2.606 & 1.409 & 0.298 \\
\hline 1.0 & 2.602 & 1.430 & 0.300 \\
\hline 1.3 & 2.597 & 1.455 & 0.302 \\
\hline 1.6 & 2.597 & 1.469 & 0.303 \\
\hline 2.0 & 2.594 & 1.488 & 0.305 \\
\hline 3.0 & 2.585 & 1.516 & 0.306 \\
\hline 4.0 & 2.572 & 1.566 & 0.309 \\
\hline 5.0 & 2.560 & 1.607 & 0.310 \\
\hline 6.0 & 2.552 & 1.647 & 0.313 \\
\hline 7.0 & 2.543 & 1.686 & 0.315 \\
\hline 8.0 & 2.534 & 1.714 & 0.315 \\
\hline 9.0 & 2.530 & 1.742 & 0.317 \\
\hline 10.0 & 2.519 & 1.768 & 0.320 \\
\hline 12.0 & 2.514 & 1.794 & 0.322 \\
\hline 14.0 & 2.507 & 1.835 & 0.325 \\
\hline 16.0 & 2.499 & 1.872 & 0.330 \\
\hline 18.0 & 2.493 & 1.901 & 0.333 \\
\hline 20.0 & 2.483 & 1.927 & 0.335 \\
\hline 25.0 & 2.480 & 1.949 & 0.339 \\
\hline 30.0 & 2.470 & 1.995 & 0.346 \\
\hline
\end{tabular}




\subsubsection{UV-Vis titration of 4 with $\mathrm{OH}^{-}$in $\mathrm{DMSO} / 0.5 \% \mathrm{H}_{2} \mathrm{O}$}

UV-Vis titration of $1 \times 10^{-4} \mathrm{M}$ solution of receptor 4 in DMSO/0.5\% $\mathrm{H}_{2} \mathrm{O}$ with $0.0075 \mathrm{M}$ solution of TBAOH (dissolved in the solution of receptor 4).

a) UV-Vis spectra

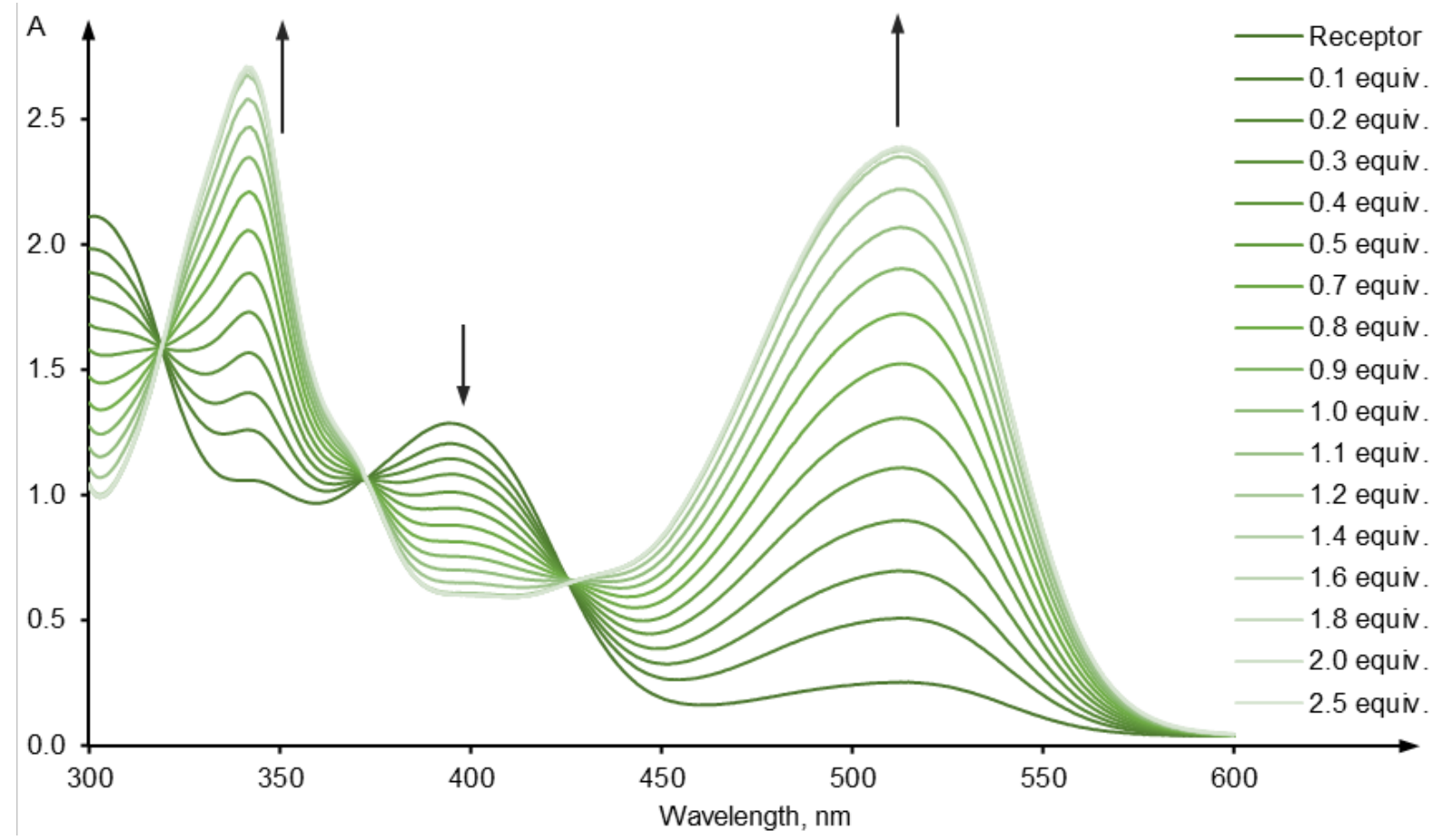

b) Raw data

\begin{tabular}{|c|c|c|c|c|}
\hline Equivalents of TBAOH & $\mathbf{3 4 6} \mathbf{~ n m}$ & $\mathbf{3 9 6} \mathbf{~ m}$ & $\mathbf{4 5 0} \mathbf{~} \mathbf{m}$ & $\mathbf{5 1 5} \mathbf{~ n m}$ \\
\hline 0.0 & 1.049 & 1.285 & 0.190 & 0.253 \\
\hline 0.1 & 1.231 & 1.204 & 0.269 & 0.508 \\
\hline 0.2 & 1.367 & 1.144 & 0.327 & 0.696 \\
\hline 0.3 & 1.515 & 1.083 & 0.388 & 0.897 \\
\hline 0.4 & 1.662 & 1.012 & 0.452 & 1.107 \\
\hline 0.5 & 1.805 & 0.948 & 0.512 & 1.305 \\
\hline 0.6 & 1.806 & 0.948 & 0.512 & 1.307 \\
\hline 0.7 & 1.961 & 0.880 & 0.576 & 1.522 \\
\hline 0.8 & 2.103 & 0.814 & 0.636 & 1.720 \\
\hline 0.9 & 2.228 & 0.756 & 0.690 & 1.901 \\
\hline 1.0 & 2.340 & 0.701 & 0.739 & 2.064 \\
\hline 1.1 & 2.441 & 0.650 & 0.784 & 2.216 \\
\hline 1.2 & 2.528 & 0.609 & 0.823 & 2.346 \\
\hline 1.4 & 2.550 & 0.602 & 0.830 & 2.372 \\
\hline 1.6 & 2.552 & 0.602 & 0.831 & 2.376 \\
\hline 1.8 & 2.553 & 0.602 & 0.831 & 2.374 \\
\hline 2.0 & 2.554 & 0.602 & 0.832 & 2.377 \\
\hline 2.5 & 2.566 & 0.604 & 0.834 & 2.386 \\
\hline
\end{tabular}




\section{Self-dissociation reversal studies}

\subsection{Self-dissociation reversal studies of receptor 3}

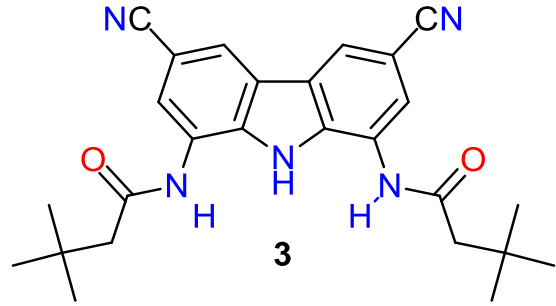

UV-Vis titration of $1 \times 10^{-4} \mathrm{M}$ solution of receptor 3 in DMSO/0.5\% $\mathrm{H}_{2} \mathrm{O}$ with $0.0075 \mathrm{M}$ solution of TfOH (dissolved in the solution of receptor 3).

a) UV-Vis spectra

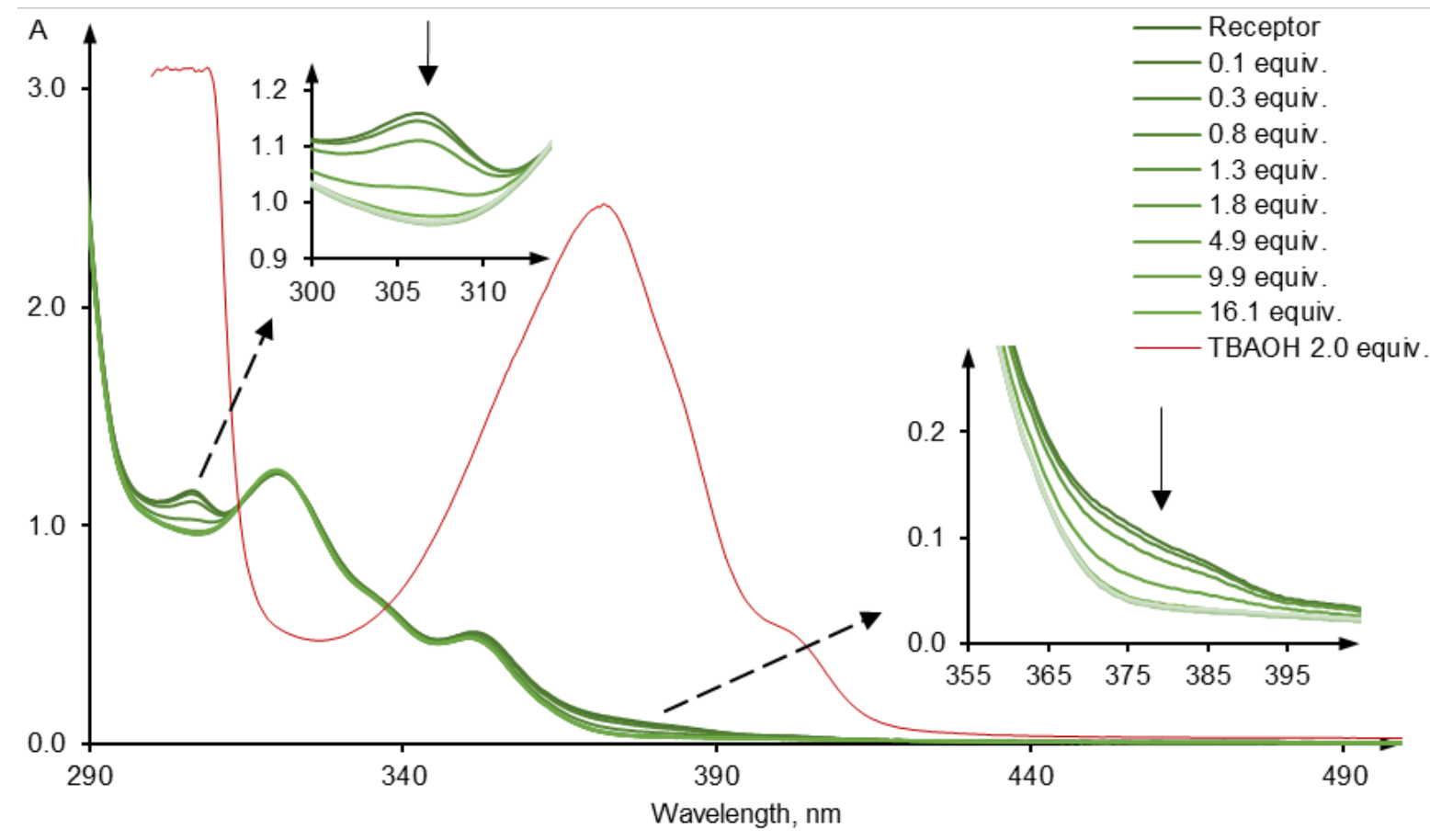

b) Titration curves
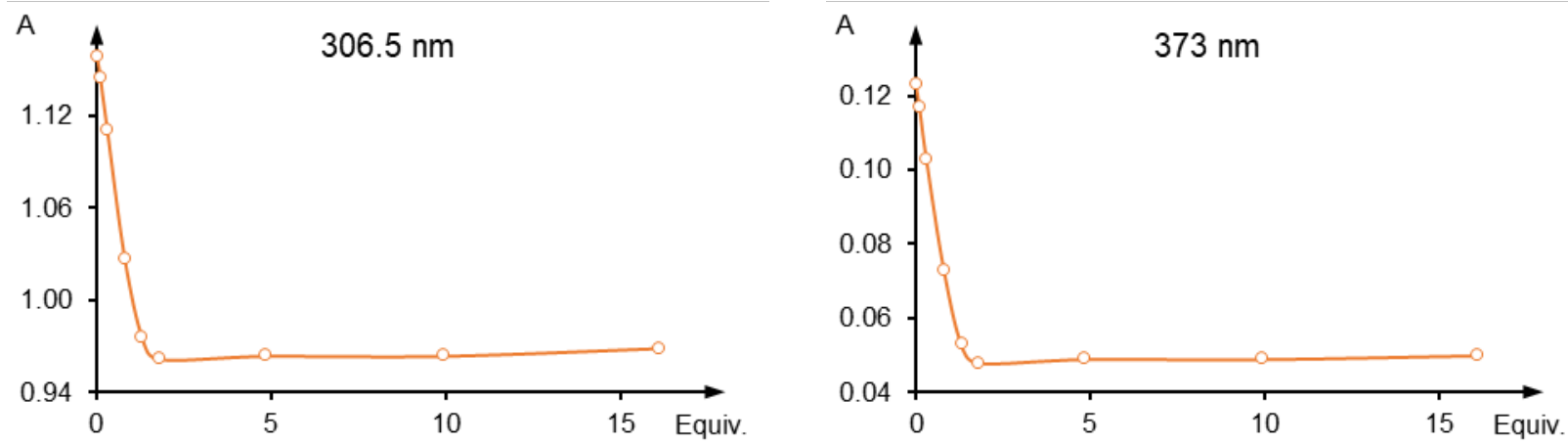
3.2 Self-dissociation reversal studies of receptor 4

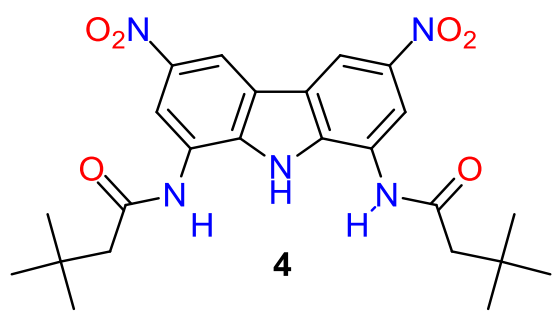

UV-Vis titration of $1 \times 10^{-4} \mathrm{M}$ solution of receptor 4 in DMSO/0.5\% $\mathrm{H}_{2} \mathrm{O}$ with $0.0075 \mathrm{M}$ solution of $\mathrm{TfOH}$ (dissolved in the solution of receptor 4).

a) UV-Vis spectra

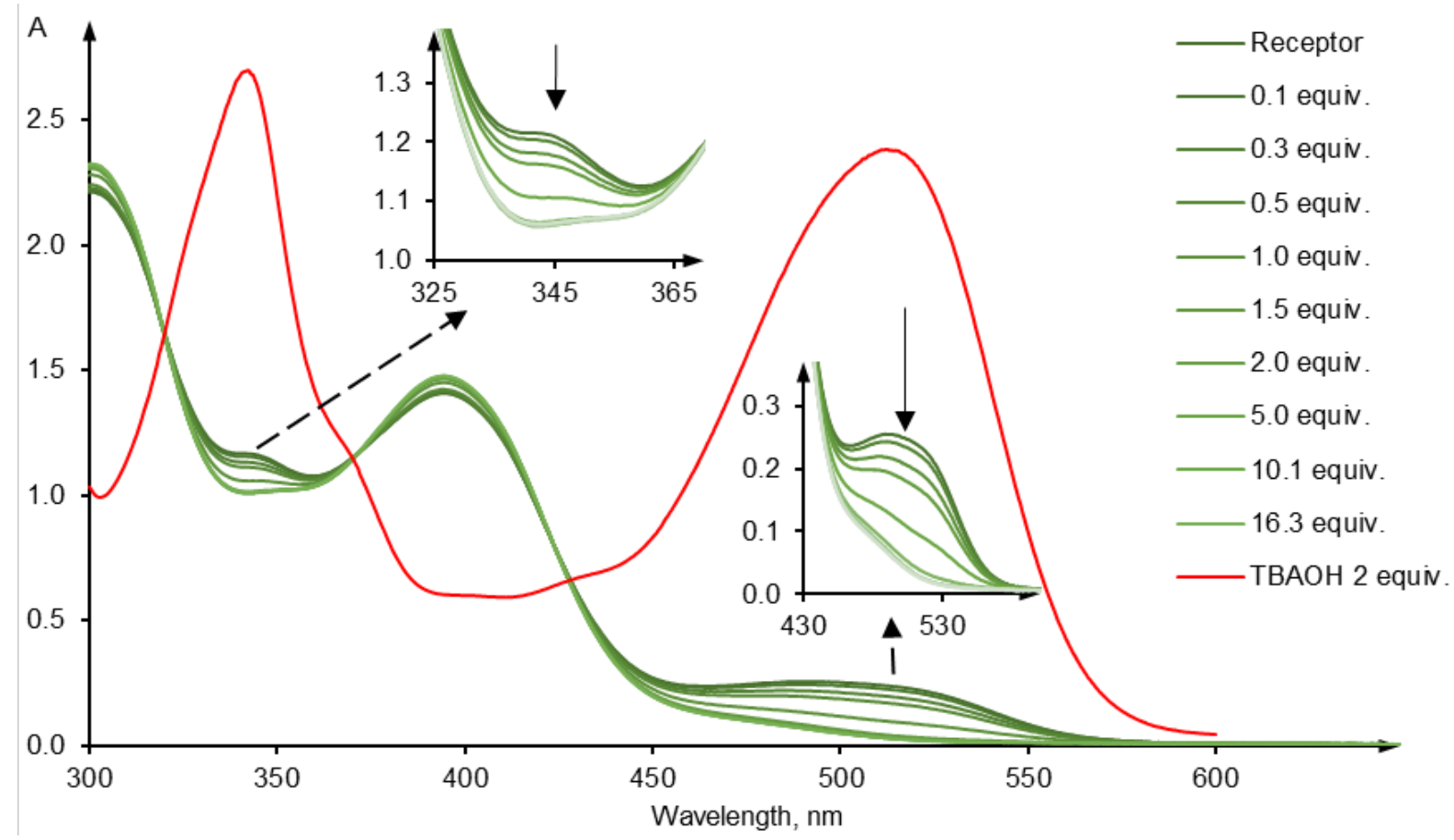

b) Titration curves
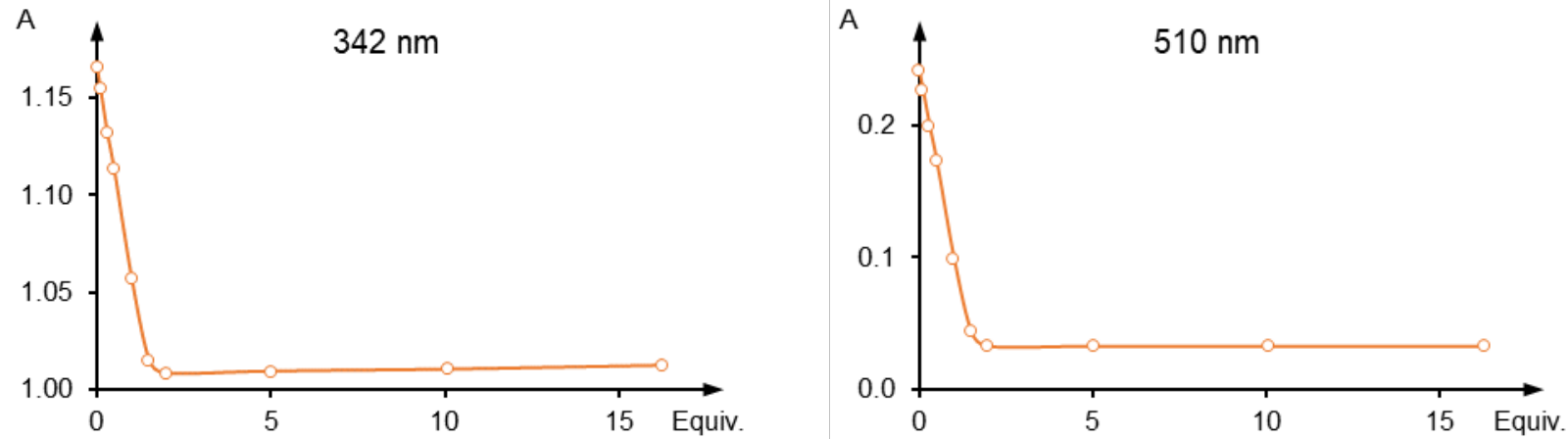


\section{Crystallographic data and refinement details}

Table S1. Crystal data and structure refinement for investigated compounds.

\begin{tabular}{|c|c|c|}
\hline Identification code & K3 (3) & K4 (4) \\
\hline CCDC deposition number & 2074344 & 2074345 \\
\hline Empirical formula & $\mathrm{C}_{110} \mathrm{H}_{122} \mathrm{Cl}_{2} \mathrm{~N}_{10} \mathrm{O}_{4} \mathrm{P}_{2}$ & $\mathrm{C}_{53} \mathrm{H}_{61} \mathrm{ClN}_{5} \mathrm{O}_{6} \mathrm{P}$ \\
\hline Formula weight & 1781.01 & 930.48 \\
\hline Temperature/K & $200.00(10)$ & $200(2)$ \\
\hline Crystal system & triclinic & triclinic \\
\hline Space group & P-1 & P-1 \\
\hline$a / \AA ̊$ & $11.2744(6)$ & $11.1012(3)$ \\
\hline$b / \AA$ & $14.0732(8)$ & $14.3129(5)$ \\
\hline$c / \AA ̊$ & $16.9993(10)$ & $17.1970(5)$ \\
\hline$\alpha /^{\circ}$ & $72.779(5)$ & $72.560(3)$ \\
\hline$B /^{\circ}$ & $84.390(5)$ & $84.207(2)$ \\
\hline$\gamma / /^{\circ}$ & $78.038(5)$ & $76.749(3)$ \\
\hline Volume $/ \AA^{3}$ & $2518.5(3)$ & $2535.90(14)$ \\
\hline$Z$ & 1 & 2 \\
\hline$\rho_{\text {calc }} \mathrm{g} / \mathrm{cm}^{3}$ & 1.174 & 1.219 \\
\hline$\mu / \mathrm{mm}^{-1}$ & 0.153 & 0.160 \\
\hline$F(000)$ & 948.0 & 988.0 \\
\hline Crystal size $/ \mathrm{mm}^{3}$ & $0.201 \times 0.104 \times 0.069$ & $0.959 \times 0.216 \times 0.152$ \\
\hline Radiation & $\operatorname{MoK} \alpha(\lambda=0.71073)$ & $\operatorname{MoK} \alpha(\lambda=0.71073)$ \\
\hline $2 \Theta$ range for data collection $/^{\circ}$ & 4.482 to 52.742 & 4.326 to 52.744 \\
\hline Index ranges & $\begin{array}{l}-14 \leq h \leq 14,-17 \leq \mathrm{k} \leq \\
17,-21 \leq \mathrm{I} \leq 21\end{array}$ & $\begin{array}{l}-13 \leq h \leq 13,-17 \leq k \leq 17, \\
-21 \leq l \leq 21\end{array}$ \\
\hline Reflections collected & 37975 & 42264 \\
\hline Independent reflections & $\begin{array}{l}10274\left[R_{\text {int }}=0.0651,\right. \\
\left.R_{\text {sigma }}=0.0784\right]\end{array}$ & $\begin{array}{l}10365\left[R_{\text {int }}=0.0334,\right. \\
\left.R_{\text {sigma }}=0.0309\right]\end{array}$ \\
\hline Data/restraints/parameters & $10274 / 30 / 633$ & $10365 / 1 / 603$ \\
\hline Goodness-of-fit on $F^{2}$ & 1.020 & 1.067 \\
\hline Final $R$ indexes $[1>=2 \sigma(I)]$ & $\begin{array}{l}R_{1}=0.0643, \\
w R_{2}=0.1226\end{array}$ & $\begin{array}{l}R_{1}=0.0538 \\
w R_{2}=0.1317\end{array}$ \\
\hline Final $R$ indexes [all data] & $\begin{array}{l}R_{1}=0.1168 \\
w R_{2}=0.1434\end{array}$ & $\begin{array}{l}R_{1}=0.0688 \\
w R_{2}=0.1401\end{array}$ \\
\hline Largest diff. peak/hole/e $\AA^{-3}$ & $0.23 /-0.25$ & $0.51 /-0.41$ \\
\hline
\end{tabular}


Table S2. Bond lengths for complex with 3.

\begin{tabular}{|c|c|c|c|c|c|}
\hline Atom & Atom & Length/Å & Atom & Atom & Length/Å \\
\hline $\mathrm{C} 2 \mathrm{~A}$ & C3A & $1.413(4)$ & $\mathrm{C} 20$ & $\mathrm{C} 25$ & $1.388(4)$ \\
\hline $\mathrm{C} 2 \mathrm{~A}$ & C7A & $1.396(4)$ & $\mathrm{C} 20$ & P19 & $1.794(3)$ \\
\hline $\mathrm{C} 2 \mathrm{~A}$ & N1A & $1.373(3)$ & $\mathrm{C} 21$ & $\mathrm{C} 22$ & $1.376(4)$ \\
\hline $\mathrm{C} 2 \mathrm{~B}$ & $\mathrm{C} 3 \mathrm{~B}$ & $1.407(4)$ & $\mathrm{C} 22$ & $\mathrm{C} 23$ & $1.377(4)$ \\
\hline $\mathrm{C} 2 \mathrm{~B}$ & C7B & $1.402(4)$ & $\mathrm{C} 23$ & $\mathrm{C} 24$ & $1.380(4)$ \\
\hline C2B & N1A & $1.369(3)$ & $\mathrm{C} 24$ & $\mathrm{C} 25$ & $1.377(4)$ \\
\hline C3A & C3B & $1.442(4)$ & $\mathrm{C} 26$ & $\mathrm{C} 27$ & $1.392(4)$ \\
\hline C3A & C4A & $1.398(4)$ & $\mathrm{C} 26$ & C31 & $1.390(4)$ \\
\hline C3B & $\mathrm{C} 4 \mathrm{~B}$ & $1.392(4)$ & $\mathrm{C} 26$ & P19 & $1.788(3)$ \\
\hline C4A & C5A & $1.382(4)$ & $\mathrm{C} 27$ & $\mathrm{C} 28$ & $1.383(4)$ \\
\hline C4B & C5B & $1.383(4)$ & $\mathrm{C} 28$ & $\mathrm{C} 29$ & $1.374(4)$ \\
\hline C5A & C6A & $1.406(4)$ & $\mathrm{C} 29$ & C30 & $1.376(4)$ \\
\hline C5A & C15A & $1.445(4)$ & C30 & C31 & $1.384(4)$ \\
\hline C5B & $\mathrm{C} 6 \mathrm{~B}$ & $1.409(4)$ & C32 & C33 & $1.383(4)$ \\
\hline C5B & C15B & $1.443(4)$ & C32 & C37 & $1.386(4)$ \\
\hline C6A & C7A & $1.385(4)$ & C32 & P19 & $1.789(3)$ \\
\hline C6B & C7B & $1.387(4)$ & C33 & C34 & $1.382(4)$ \\
\hline C7A & N8A & $1.403(3)$ & C34 & C35 & $1.360(5)$ \\
\hline C7B & N8B & $1.407(3)$ & C35 & C36 & $1.369(5)$ \\
\hline C9A & $\mathrm{C} 10 \mathrm{~A}$ & $1.501(4)$ & C36 & C37 & $1.382(5)$ \\
\hline C9A & N8A & $1.369(3)$ & C38 & C39 & $1.393(4)$ \\
\hline C9A & O17A & $1.218(3)$ & C38 & $\mathrm{C} 43$ & $1.393(4)$ \\
\hline C9B & $\mathrm{C} 10 \mathrm{~B}$ & $1.508(4)$ & C38 & P19 & $1.789(3)$ \\
\hline C9B & N8B & $1.366(3)$ & C39 & $\mathrm{C} 40$ & $1.379(4)$ \\
\hline C9B & O17B & $1.218(3)$ & $\mathrm{C} 40$ & C41 & $1.377(5)$ \\
\hline C10A & C11A & $1.535(4)$ & C41 & $\mathrm{C} 42$ & $1.371(4)$ \\
\hline $\mathrm{C} 10 \mathrm{~B}$ & $\mathrm{C} 11 \mathrm{~B}$ & $1.544(4)$ & $\mathrm{C} 42$ & $\mathrm{C} 43$ & $1.385(4)$ \\
\hline C11A & C12A & $1.524(5)$ & C44B & C45B & $1.388(10)$ \\
\hline C11A & C13A & $1.530(4)$ & C45B & C46B & $1.387(11)$ \\
\hline C11A & C14A & $1.514(5)$ & C46B & C47B & $1.397(11)$ \\
\hline $\mathrm{C} 11 \mathrm{~B}$ & C12B & $1.522(4)$ & C47B & C48B & $1.406(11)$ \\
\hline $\mathrm{C} 11 \mathrm{~B}$ & $\mathrm{C} 13 \mathrm{~B}$ & $1.532(4)$ & C44A & C45A & $1.379(13)$ \\
\hline C11B & C14B & $1.522(4)$ & C45A & C46A & $1.376(14)$ \\
\hline C15A & N16A & $1.137(4)$ & C46A & C47A & $1.382(14)$ \\
\hline C15B & N16B & $1.141(3)$ & C47A & C48A & $1.384(13)$ \\
\hline $\mathrm{C} 20$ & $\mathrm{C} 21$ & $1.392(4)$ & & & \\
\hline
\end{tabular}


Table S3. Valence angles for complex with 3.

\begin{tabular}{|c|c|c|c|c|c|c|c|}
\hline Atom & Atom & Atom & Angle/ $^{\circ}$ & Atom & Atom & Atom & Angle/ $/^{\circ}$ \\
\hline C7A & $\mathrm{C} 2 \mathrm{~A}$ & C3A & $123.3(2)$ & N16B & C15B & C5B & 179.7(4) \\
\hline N1A & $\mathrm{C} 2 \mathrm{~A}$ & C3A & $108.8(2)$ & $\mathrm{C} 2 \mathrm{~B}$ & $\mathrm{~N} 1 \mathrm{~A}$ & $\mathrm{C} 2 \mathrm{~A}$ & $109.1(2)$ \\
\hline N1A & $\mathrm{C} 2 \mathrm{~A}$ & C7A & $127.9(2)$ & C9A & N8A & C7A & $127.6(2)$ \\
\hline C7B & $\mathrm{C} 2 \mathrm{~B}$ & C3B & $122.9(2)$ & $\mathrm{C} 9 \mathrm{~B}$ & N8B & C7B & $127.9(2)$ \\
\hline N1A & $\mathrm{C} 2 \mathrm{~B}$ & C3B & $109.5(2)$ & $\mathrm{C} 21$ & $\mathrm{C} 20$ & P19 & $120.3(2)$ \\
\hline N1A & $\mathrm{C} 2 \mathrm{~B}$ & C7B & $127.6(2)$ & $\mathrm{C} 25$ & $\mathrm{C} 20$ & $\mathrm{C} 21$ & $119.3(3)$ \\
\hline $\mathrm{C} 2 \mathrm{~A}$ & C3A & C3B & $106.5(2)$ & $\mathrm{C} 25$ & $\mathrm{C} 20$ & P19 & $120.3(2)$ \\
\hline C4A & C3A & $\mathrm{C} 2 \mathrm{~A}$ & $119.2(3)$ & $\mathrm{C} 22$ & $\mathrm{C} 21$ & $\mathrm{C} 20$ & $120.1(3)$ \\
\hline C4A & $\mathrm{C} 3 \mathrm{~A}$ & C3B & $134.3(3)$ & $\mathrm{C} 21$ & $\mathrm{C} 22$ & $\mathrm{C} 23$ & $120.2(3)$ \\
\hline $\mathrm{C} 2 \mathrm{~B}$ & C3B & C3A & $106.1(2)$ & $\mathrm{C} 22$ & $\mathrm{C} 23$ & $\mathrm{C} 24$ & $120.1(3)$ \\
\hline C4B & C3B & $\mathrm{C} 2 \mathrm{~B}$ & $119.8(3)$ & $\mathrm{C} 25$ & $\mathrm{C} 24$ & $\mathrm{C} 23$ & $120.1(3)$ \\
\hline C4B & C3B & C3A & $134.1(3)$ & $\mathrm{C} 24$ & $\mathrm{C} 25$ & $\mathrm{C} 20$ & $120.1(3)$ \\
\hline C5A & $\mathrm{C} 4 \mathrm{~A}$ & C3A & $117.6(3)$ & $\mathrm{C} 27$ & $\mathrm{C} 26$ & P19 & $119.6(2)$ \\
\hline C5B & C4B & C3B & 117.1(3) & C31 & $\mathrm{C} 26$ & $\mathrm{C} 27$ & 119.6(3) \\
\hline C4A & C5A & $\mathrm{C} 6 \mathrm{~A}$ & $122.7(3)$ & C31 & $\mathrm{C} 26$ & P19 & $120.8(2)$ \\
\hline C4A & C5A & C15A & $120.8(3)$ & $\mathrm{C} 28$ & $\mathrm{C} 27$ & $\mathrm{C} 26$ & 119.5(3) \\
\hline C6A & C5A & C15A & $116.6(3)$ & $\mathrm{C} 29$ & $\mathrm{C} 28$ & $\mathrm{C} 27$ & $120.7(3)$ \\
\hline C4B & C5B & C6B & $123.3(2)$ & $\mathrm{C} 28$ & $\mathrm{C} 29$ & C30 & $120.1(3)$ \\
\hline $\mathrm{C} 4 \mathrm{~B}$ & C5B & $\mathrm{C} 15 \mathrm{~B}$ & $119.3(3)$ & $\mathrm{C} 29$ & $\mathrm{C} 30$ & C31 & $120.1(3)$ \\
\hline C6B & C5B & $\mathrm{C} 15 \mathrm{~B}$ & $117.4(3)$ & C30 & C31 & $\mathrm{C} 26$ & $120.0(3)$ \\
\hline C7A & C6A & C5A & $120.8(3)$ & C33 & C32 & C37 & 119.3(3) \\
\hline C7B & $\mathrm{C} 6 \mathrm{~B}$ & C5B & $120.0(3)$ & C33 & C32 & P19 & $119.5(2)$ \\
\hline $\mathrm{C} 2 \mathrm{~A}$ & C7A & N8A & $118.3(2)$ & C37 & C32 & P19 & $120.9(2)$ \\
\hline C6A & C7A & $\mathrm{C} 2 \mathrm{~A}$ & $116.5(2)$ & C34 & C33 & C32 & $120.4(3)$ \\
\hline C6A & C7A & N8A & $125.2(3)$ & C35 & C34 & C33 & 119.7(3) \\
\hline $\mathrm{C} 2 \mathrm{~B}$ & C7B & N8B & $118.3(2)$ & C34 & C35 & C36 & $120.8(3)$ \\
\hline C6B & C7B & $\mathrm{C} 2 \mathrm{~B}$ & $116.8(2)$ & C35 & C36 & C37 & $120.2(3)$ \\
\hline C6B & C7B & N8B & $124.9(2)$ & C36 & C37 & C32 & 119.6(3) \\
\hline N8A & C9A & $\mathrm{C} 10 \mathrm{~A}$ & $114.1(2)$ & C39 & C38 & P19 & $119.6(2)$ \\
\hline O17A & $\mathrm{C9A}$ & $\mathrm{C} 10 \mathrm{~A}$ & $123.1(3)$ & $\mathrm{C} 43$ & C38 & C39 & $119.5(3)$ \\
\hline O17A & $\mathrm{C9A}$ & N8A & $122.8(3)$ & $\mathrm{C} 43$ & C38 & P19 & $120.8(2)$ \\
\hline N8B & $\mathrm{C} 9 \mathrm{~B}$ & $\mathrm{C} 10 \mathrm{~B}$ & $114.6(2)$ & $\mathrm{C} 40$ & C39 & C38 & $120.0(3)$ \\
\hline O17B & $\mathrm{C} 9 \mathrm{~B}$ & $\mathrm{C} 10 \mathrm{~B}$ & $122.9(3)$ & $\mathrm{C} 41$ & $\mathrm{C} 40$ & C39 & $120.2(3)$ \\
\hline O17B & $\mathrm{C} 9 \mathrm{~B}$ & $\mathrm{~N} 8 \mathrm{~B}$ & $122.5(3)$ & $\mathrm{C} 42$ & C41 & $\mathrm{C} 40$ & $120.3(3)$ \\
\hline C9A & $\mathrm{C} 10 \mathrm{~A}$ & $\mathrm{C} 11 \mathrm{~A}$ & $115.3(2)$ & C41 & $\mathrm{C} 42$ & $\mathrm{C} 43$ & $120.6(3)$ \\
\hline C9B & $\mathrm{C} 10 \mathrm{~B}$ & $\mathrm{C} 11 \mathrm{~B}$ & $115.6(2)$ & $\mathrm{C} 42$ & $\mathrm{C} 43$ & C38 & $119.5(3)$ \\
\hline $\mathrm{C} 12 \mathrm{~A}$ & C11A & C10A & $110.8(3)$ & $\mathrm{C} 26$ & P19 & $\mathrm{C} 20$ & $109.55(12)$ \\
\hline
\end{tabular}




\begin{tabular}{llllllll}
\hline C12A & C11A & C13A & $109.0(3)$ & C26 & P19 & C32 & $109.36(13)$ \\
C13A & C11A & C10A & $106.6(3)$ & C26 & P19 & C38 & $111.53(13)$ \\
C14A & C11A & C10A & $110.2(3)$ & C32 & P19 & C20 & $108.10(13)$ \\
C14A & C11A & C12A & $109.6(3)$ & C32 & P19 & C38 & $109.30(12)$ \\
C14A & C11A & C13A & $110.6(3)$ & C38 & P19 & C20 & $108.93(13)$ \\
C12B & C11B & C10B & $111.4(2)$ & C46B & C45B & C44B & $127.2(15)$ \\
C12B & C11B & C13B & $109.7(3)$ & C45B & C46B & C47B & $133.3(15)$ \\
C13B & C11B & C10B & $106.7(2)$ & C46B & C47B & C48B & $124.4(13)$ \\
C14B & C11B & C10B & $110.0(2)$ & C46A & C45A & C44A & $133(2)$ \\
C14B & C11B & C12B & $109.2(3)$ & C45A & C46A & C47A & $165(3)$ \\
C14B & C11B & C13B & $109.8(3)$ & C46A & C47A & C48A & $132(3)$ \\
N16A & C15A & C5A & $177.9(3)$ & & & & \\
\hline
\end{tabular}


Table S4. Bond lengths for complex with 4.

\begin{tabular}{|c|c|c|c|c|c|}
\hline Atom & Atom & Length/Å & Atom & Atom & Length/Å \\
\hline $\mathrm{N} 1 \mathrm{~A}$ & $\mathrm{C} 2 \mathrm{~A}$ & $1.372(3)$ & N15B & O16B & $1.218(3)$ \\
\hline N1A & $\mathrm{C} 2 \mathrm{~B}$ & $1.374(3)$ & N15B & O17B & $1.223(3)$ \\
\hline $\mathrm{C} 2 \mathrm{~A}$ & C $3 \mathrm{~A}$ & $1.408(3)$ & P19 & $\mathrm{C} 20$ & $1.786(2)$ \\
\hline $\mathrm{C} 2 \mathrm{~A}$ & C7A & $1.407(3)$ & P19 & $\mathrm{C} 26$ & $1.792(2)$ \\
\hline $\mathrm{C} 2 \mathrm{~B}$ & $\mathrm{C} 3 \mathrm{~B}$ & $1.410(3)$ & P19 & C32 & $1.796(2)$ \\
\hline $\mathrm{C} 2 \mathrm{~B}$ & C7B & $1.406(3)$ & P19 & C38 & $1.793(2)$ \\
\hline C3A & C3B & $1.446(3)$ & $\mathrm{C} 20$ & $\mathrm{C} 21$ & $1.400(3)$ \\
\hline C3A & C4A & $1.395(3)$ & $\mathrm{C} 20$ & $\mathrm{C} 25$ & $1.389(3)$ \\
\hline C3B & $\mathrm{C} 4 \mathrm{~B}$ & $1.393(3)$ & $\mathrm{C} 21$ & $\mathrm{C} 22$ & $1.383(4)$ \\
\hline C4A & C5A & $1.378(3)$ & $\mathrm{C} 22$ & $\mathrm{C} 23$ & $1.374(4)$ \\
\hline C4B & C5B & $1.377(3)$ & $\mathrm{C} 23$ & $\mathrm{C} 24$ & $1.381(4)$ \\
\hline C5A & C6A & $1.399(3)$ & $\mathrm{C} 24$ & $\mathrm{C} 25$ & $1.379(3)$ \\
\hline C5A & N15A & $1.464(3)$ & $\mathrm{C} 26$ & $\mathrm{C} 27$ & $1.394(3)$ \\
\hline C5B & $\mathrm{C} 6 \mathrm{~B}$ & $1.402(3)$ & $\mathrm{C} 26$ & C31 & $1.390(3)$ \\
\hline C5B & N15B & $1.464(3)$ & $\mathrm{C} 27$ & C28 & $1.385(4)$ \\
\hline C6A & C7A & $1.384(3)$ & $\mathrm{C} 28$ & C29 & $1.377(4)$ \\
\hline C6B & C7B & $1.385(3)$ & $\mathrm{C} 29$ & C30 & $1.375(4)$ \\
\hline C7A & N8A & $1.405(3)$ & C30 & C31 & $1.389(4)$ \\
\hline C7B & N8B & $1.406(3)$ & C32 & C33 & $1.399(3)$ \\
\hline N8A & C9A & $1.371(3)$ & C32 & C37 & $1.395(3)$ \\
\hline N8B & $\mathrm{C} 9 \mathrm{~B}$ & $1.368(3)$ & C33 & C34 & $1.377(3)$ \\
\hline C9A & C10A & $1.502(3)$ & C34 & C35 & $1.383(4)$ \\
\hline C9A & O18A & $1.222(3)$ & C35 & C36 & $1.386(4)$ \\
\hline $\mathrm{C} 9 \mathrm{~B}$ & $\mathrm{C} 10 \mathrm{~B}$ & $1.510(3)$ & C36 & C37 & $1.382(3)$ \\
\hline $\mathrm{C} 9 \mathrm{~B}$ & O18B & $1.218(3)$ & C38 & C39 & $1.387(3)$ \\
\hline C10A & C11A & $1.541(4)$ & C38 & $\mathrm{C} 43$ & $1.391(3)$ \\
\hline $\mathrm{C} 10 \mathrm{~B}$ & $\mathrm{C} 11 \mathrm{~B}$ & $1.542(3)$ & C39 & $\mathrm{C} 40$ & $1.389(4)$ \\
\hline $\mathrm{C} 11 \mathrm{~A}$ & $\mathrm{C} 12 \mathrm{~A}$ & $1.525(4)$ & $\mathrm{C} 40$ & C41 & $1.368(5)$ \\
\hline C11A & C13A & $1.532(4)$ & C41 & $\mathrm{C} 42$ & $1.379(5)$ \\
\hline C11A & C14A & $1.521(4)$ & $\mathrm{C} 42$ & $\mathrm{C} 43$ & $1.382(4)$ \\
\hline C11B & C12B & $1.525(3)$ & $\mathrm{C} 45$ & $\mathrm{C} 46$ & $1.337(8)$ \\
\hline C11B & C13B & $1.529(4)$ & $\mathrm{C} 46$ & $\mathrm{C} 47$ & $1.414(8)$ \\
\hline C11B & C14B & $1.522(4)$ & $\mathrm{C} 47$ & $\mathrm{C} 48$ & $1.415(9)$ \\
\hline N15A & O16A & $1.227(3)$ & $\mathrm{C} 48$ & C49 & $1.359(8)$ \\
\hline N15A & O17A & $1.228(3)$ & & & \\
\hline
\end{tabular}


Table S5. Valence angles for complex with 4.

\begin{tabular}{|c|c|c|c|c|c|c|c|}
\hline Atom & Atom & Atom & Angle/ $/^{\circ}$ & Atom & Atom & Atom & Angle/ $/^{\circ}$ \\
\hline $\mathrm{C} 2 \mathrm{~A}$ & N1A & $\mathrm{C} 2 \mathrm{~B}$ & $108.97(18)$ & C14B & C11B & $\mathrm{C} 12 \mathrm{~B}$ & $109.2(2)$ \\
\hline N1A & $\mathrm{C} 2 \mathrm{~A}$ & $\mathrm{C} 3 \mathrm{~A}$ & $109.40(18)$ & C14B & C11B & $\mathrm{C} 13 \mathrm{~B}$ & $110.2(3)$ \\
\hline N1A & $\mathrm{C} 2 \mathrm{~A}$ & C7A & $127.9(2)$ & O16A & N15A & C5A & 118.23(19) \\
\hline C7A & $\mathrm{C} 2 \mathrm{~A}$ & C3A & $122.7(2)$ & O16A & N15A & O17A & $122.8(2)$ \\
\hline N1A & $\mathrm{C} 2 \mathrm{~B}$ & C3B & 109.09(18) & O17A & N15A & C5A & 118.95(19) \\
\hline N1A & $\mathrm{C} 2 \mathrm{~B}$ & C7B & $127.8(2)$ & O16B & N15B & C5B & $118.6(2)$ \\
\hline C7B & $\mathrm{C} 2 \mathrm{~B}$ & C3B & $123.07(19)$ & O16B & N15B & O17B & $122.5(2)$ \\
\hline $\mathrm{C} 2 \mathrm{~A}$ & $\mathrm{C} 3 \mathrm{~A}$ & C3B & 106.18(19) & O17B & N15B & C5B & $118.9(2)$ \\
\hline $\mathrm{C} 4 \mathrm{~A}$ & $\mathrm{C} 3 \mathrm{~A}$ & $\mathrm{C} 2 \mathrm{~A}$ & $120.12(19)$ & $\mathrm{C} 20$ & P19 & $\mathrm{C} 26$ & 111.18(11) \\
\hline C4A & C3A & C3B & $133.7(2)$ & $\mathrm{C} 20$ & P19 & C32 & $109.26(10)$ \\
\hline $\mathrm{C} 2 \mathrm{~B}$ & C3B & C3A & $106.36(18)$ & $\mathrm{C} 20$ & P19 & C38 & $109.87(11)$ \\
\hline C4B & C3B & $\mathrm{C} 2 \mathrm{~B}$ & $119.8(2)$ & $\mathrm{C} 26$ & P19 & C32 & $109.38(10)$ \\
\hline C4B & C3B & C3A & $133.9(2)$ & $\mathrm{C} 26$ & P19 & C38 & $109.42(10)$ \\
\hline C5A & $\mathrm{C} 4 \mathrm{~A}$ & C $3 \mathrm{~A}$ & $116.1(2)$ & C38 & P19 & C32 & $107.66(11)$ \\
\hline C5B & C4B & C3B & $116.3(2)$ & $\mathrm{C} 21$ & $\mathrm{C} 20$ & P19 & $120.01(18)$ \\
\hline C4A & C5A & $\mathrm{C} 6 \mathrm{~A}$ & $124.8(2)$ & $\mathrm{C} 25$ & $\mathrm{C} 20$ & P19 & $120.40(17)$ \\
\hline C4A & C5A & N15A & $118.3(2)$ & $\mathrm{C} 25$ & $\mathrm{C} 20$ & $\mathrm{C} 21$ & $119.6(2)$ \\
\hline C6A & C5A & N15A & 116.92(19) & $\mathrm{C} 22$ & $\mathrm{C} 21$ & $\mathrm{C} 20$ & $119.5(2)$ \\
\hline $\mathrm{C} 4 \mathrm{~B}$ & C5B & $\mathrm{C} 6 \mathrm{~B}$ & $124.9(2)$ & $\mathrm{C} 23$ & $\mathrm{C} 22$ & $\mathrm{C} 21$ & $120.4(2)$ \\
\hline C4B & C5B & N15B & $117.9(2)$ & $\mathrm{C} 22$ & $\mathrm{C} 23$ & $\mathrm{C} 24$ & $120.3(2)$ \\
\hline C6B & C5B & N15B & $117.23(19)$ & $\mathrm{C} 25$ & $\mathrm{C} 24$ & $\mathrm{C} 23$ & $120.2(2)$ \\
\hline C7A & C6A & C5A & $119.5(2)$ & $\mathrm{C} 24$ & $\mathrm{C} 25$ & $\mathrm{C} 20$ & $120.0(2)$ \\
\hline C7B & $\mathrm{C} 6 \mathrm{~B}$ & C5B & $119.3(2)$ & $\mathrm{C} 27$ & $\mathrm{C} 26$ & P19 & $119.61(18)$ \\
\hline C6A & C7A & $\mathrm{C} 2 \mathrm{~A}$ & $116.8(2)$ & C31 & $\mathrm{C} 26$ & P19 & $120.50(19)$ \\
\hline C6A & C7A & N8A & 124.93(19) & C31 & $\mathrm{C} 26$ & $\mathrm{C} 27$ & 119.7(2) \\
\hline N8A & C7A & $\mathrm{C} 2 \mathrm{~A}$ & 118.29(19) & $\mathrm{C} 28$ & $\mathrm{C} 27$ & $\mathrm{C} 26$ & $120.0(3)$ \\
\hline C6B & C7B & $\mathrm{C} 2 \mathrm{~B}$ & $116.7(2)$ & $\mathrm{C} 29$ & $\mathrm{C} 28$ & $\mathrm{C} 27$ & $120.0(3)$ \\
\hline C6B & C7B & N8B & $125.13(19)$ & C30 & $\mathrm{C} 29$ & $\mathrm{C} 28$ & $120.4(2)$ \\
\hline N8B & C7B & $\mathrm{C} 2 \mathrm{~B}$ & $118.21(19)$ & $\mathrm{C} 29$ & C30 & C31 & $120.4(3)$ \\
\hline C9A & N8A & C7A & $127.63(19)$ & C30 & C31 & $\mathrm{C} 26$ & $119.5(3)$ \\
\hline C9B & N8B & C7B & $128.05(19)$ & C33 & C32 & P19 & $119.62(18)$ \\
\hline N8A & C9A & C10A & 114.26(19) & C37 & C32 & P19 & $120.69(17)$ \\
\hline O18A & C9A & N8A & $122.7(2)$ & C37 & C32 & C33 & $119.6(2)$ \\
\hline O18A & $\mathrm{C9A}$ & C10A & $123.1(2)$ & C34 & C33 & C32 & $119.9(2)$ \\
\hline N8B & $\mathrm{C} 9 \mathrm{~B}$ & $\mathrm{C} 10 \mathrm{~B}$ & $114.81(19)$ & C33 & C34 & C35 & $120.3(2)$ \\
\hline O18B & $\mathrm{C} 9 \mathrm{~B}$ & N8B & $122.4(2)$ & C34 & C35 & C36 & $120.2(2)$ \\
\hline O18B & $\mathrm{C} 9 \mathrm{~B}$ & C10B & $122.8(2)$ & C37 & C36 & C35 & $120.1(2)$ \\
\hline
\end{tabular}




\begin{tabular}{llllllll}
\hline C9A & C10A & C11A & $114.8(2)$ & C36 & C37 & C32 & $119.9(2)$ \\
C9B & C10B & C11B & $115.8(2)$ & C39 & C38 & P19 & $119.31(19)$ \\
C12A & C11A & C10A & $111.3(2)$ & C39 & C38 & C43 & $120.0(2)$ \\
C12A & C11A & C13A & $109.1(2)$ & C43 & C38 & P19 & $120.22(19)$ \\
C13A & C11A & C10A & $106.4(2)$ & C38 & C39 & C40 & $119.9(3)$ \\
C14A & C11A & C10A & $110.0(2)$ & C41 & C40 & C39 & $119.8(3)$ \\
C14A & C11A & C12A & $109.5(3)$ & C40 & C41 & C42 & $120.6(3)$ \\
C14A & C11A & C13A & $110.5(3)$ & C41 & C42 & C43 & $120.4(3)$ \\
C12B & C11B & C10B & $111.3(2)$ & C42 & C43 & C38 & $119.2(3)$ \\
C12B & C11B & C13B & $109.5(3)$ & C45 & C46 & C47 & $130.8(8)$ \\
C13B & C11B & C10B & $106.0(2)$ & C48 & C47 & C46 & $131.5(7)$ \\
C14B & C11B & C10B & $110.6(2)$ & C49 & C48 & C47 & $130.3(8)$ \\
\hline
\end{tabular}

4.1 ${ }^{1} \mathrm{H}$ NMR of crystallised complex $\left[4 \times \mathrm{Ph}_{4} \mathrm{PCl}\right]$ dissolved in $\mathrm{CDCl}_{3}$

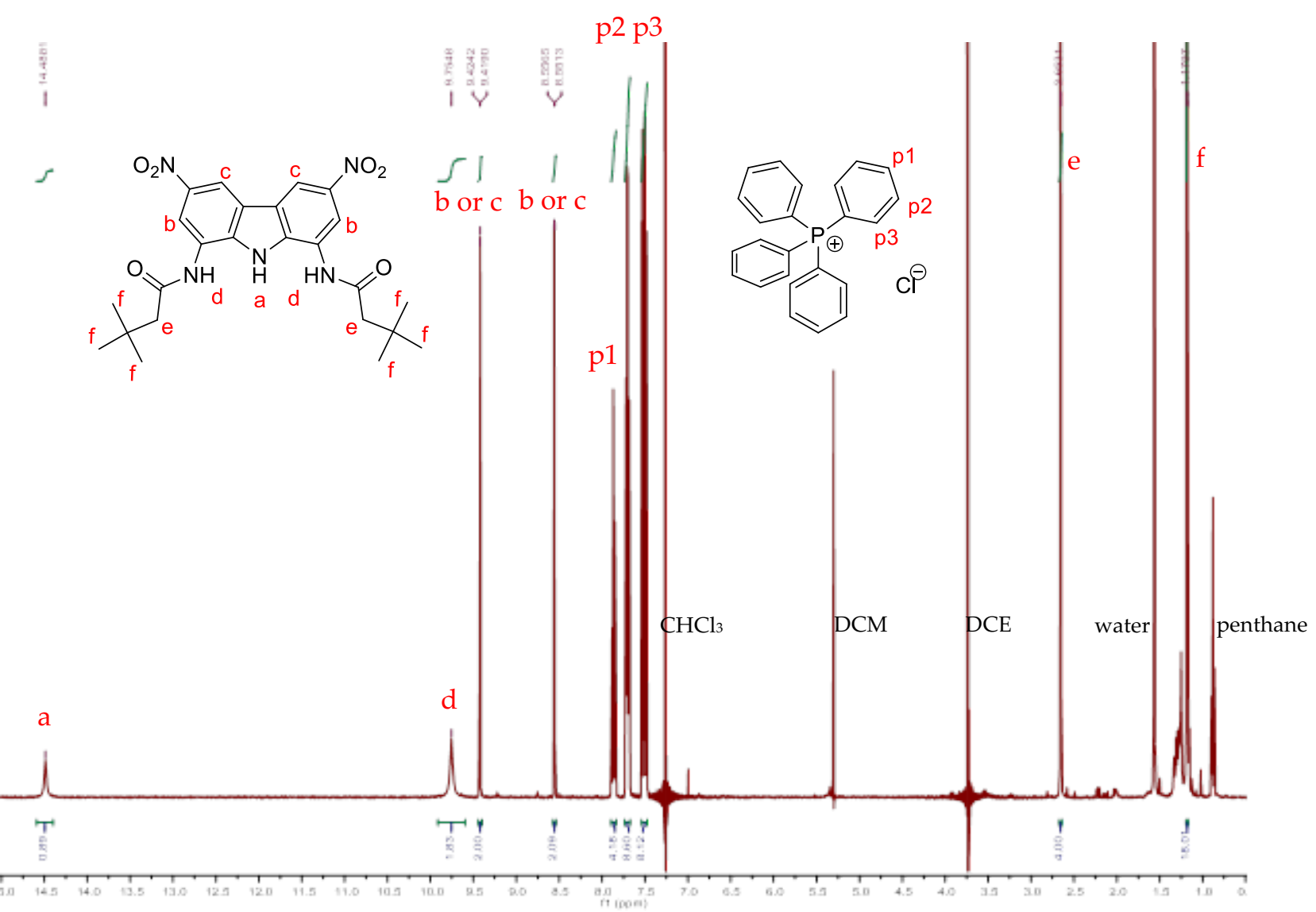

